TALITA STESSUK

\title{
TERAPIA CELULAR EM ÚLCERAS CRÔNICAS COM IMPLANTE DE CÉLULAS TRONCO MESENQUIMAIS ASSOCIADAS A PLASMA RICO EM PLAQUETAS
}

Tese apresentada ao Programa de PósGraduação Interunidades em Biotecnologia USP/Instituto Butantan/IPT, para obtenção do Título de Doutor em Biotecnologia.

São Paulo 


\section{TALITA STESSUK}

\section{TERAPIA CELULAR EM ÚLCERAS CRÔNICAS COM IMPLANTE DE CÉLULAS TRONCO MESENQUIMAIS ASSOCIADAS A PLASMA RICO EM PLAQUETAS}

Tese apresentada ao Programa de PósGraduação Interunidades em Biotecnologia USP/Instituto Butantan/IPT, para obtenção do Título de Doutor em Biotecnologia.

Área de concentração: Biotecnologia

Orientador: Prof. Dr. João Tadeu RibeiroPaes

Versão corrigida. A versão original eletrônica encontra-se disponível tanto na Biblioteca do ICB quanto na Biblioteca Digital de Teses e Dissertações da USP (BDTD). 
DADOS DE CATALOGAÇÃO NA PUBLICAÇÃO (CIP)

Serviço de Biblioteca e Informação Biomédica do Instituto de Ciências Biomédicas da Universidade de São Paulo

(C) reprodução total

Stessuk, Talita.

Terapia celular em úlceras crônicas com implante de células-tronco mesenquimais associadas a plasma rico em plaquetas / Talita Stessuk. -- São Paulo, 2016.

Orientador: Prof. Dr. João Tadeu Ribeiro Paes.

Tese (Doutorado) - Universidade de São Paulo. Instituto de Ciências Biomédicas. Programa de Pós-Graduação Interunidades em Biotecnologia USP/IPT/Instituto Butantan. Área de concentração: Biotecnologia. Linha de pesquisa: Terapia celular.

Versão do título para o inglês: Cell therapy in chronic ulcers with implant of mesenchymal stem cells associated with platelet-rich plasma.

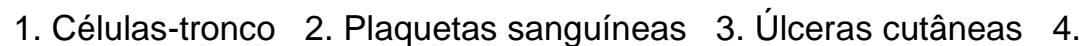
Terapia biológica 5. Dermatologia 6. Diabetes mellitus I. Paes, Prof. Dr. João Tadeu Ribeiro II. Universidade de São Paulo. Instituto de Ciências Biomédicas. Programa de Pós-Graduação Interunidades em Biotecnologia USP/IPT/Instituto Butantan III. Título. 


\section{UNIVERSIDADE DE SÃO PAULO \\ Programa de Pós-Graduação Interunidades em Biotecnologia}

Universidade de São Paulo, Instituto Butantan, Instituto de Pesquisas Tecnológicas

Candidato(a):

Talita Stessuk.

Título da Tese:

Terapia celular em úlceras crônicas com implante de células-tronco mesenquimais associadas a plasma rico em plaquetas.

Orientador(a):

Prof. Dr. João Tadeu Ribeiro Paes.

A Comissão Julgadora dos trabalhos de Defesa da Tese de Doutorado, em sessão pública realizada a , considerou

( ) Aprovado(a)

( ) Reprovado(a)

Examinador(a): Assinatura:

Nome:

Instituição:

Examinador(a): Assinatura:

Nome:

Instituição:

Examinador(a): Assinatura:

Nome:

Instituição:

Examinador(a): Assinatura:

Nome:

Instituição:

Presidente: Assinatura:

Nome:

Instituição: 


\section{FACULDADE DE CIENCIAS MEDICAS - UNICAMP (CAMPUS CAMPINAS)}

\section{PARECER CONSUBSTANCIADO DO CEP}

\section{DADOS DO PROJETO DE PESQUISA}

Título da Pesquisa: TERAPIA CELULAR EM ÚLCERAS VENOSAS COM IMPLANTE DE CÉLULAS TRONCO MESENQUIMAIS ASSOCIADAS A PLASMA RICO EM PLAQUETAS

Pesquisador: Talita Stessuk

Área Temática:

Versão: 3

CAAE: 11214513.6 .0000 .5404

Instituição Proponente: Hospital de Clínicas da UNICAMP

Patrocinador Principal: Financiamento Próprio

\section{DADOS DO PARECER}

Número do Parecer: 256.671

Data da Relatoria: 15/04/2013

\section{Apresentação do Projeto:}

É proposto "estudo clínico prospectivo para avaliação da eficácia referente ao emprego de plasma rico em plaquetas sob a forma gel associado a células-tronco mesenquimais derivadas do tecido adiposo em úlceras venosas. Todos os tipos celulares serão obtidos do próprio paciente, caracterizando um procedimento integralmente autólogo. Todos os pacientes serão acompanhados durante noventa dias no ambulatório de Feridas da Disciplina de Dermatologia e no ambulatório de Úlceras Venosas da Disciplina de Cirurgia Vascular do Departamento de Cirurgia, ambos os ambulatórios da Faculdade de Ciências Médicas da Universidade Estadual de Campinas - UNICAMP. Após obedecidos os critérios de inclusão e exclusão, os pacientes portadores de úlceras venosas, submetidos à abordagens terapêuticas convencionais sem melhora clínica significativa, serão convidados a participarem do estudo, mediante concordância, leitura e assinatura do Termo de Consentimento Livre e Esclarecido. Os pacientes serão submetidos à microlipoaspiração na região da prega glútea para isolamento e cultura de células-tronco mesenquimais. Aproximadamente 25 dias após a microlipoaspiração, os pacientes serão submetidos à coleta de sangue para preparo do plasma rico em plaquetas. Haverá administração tópica de plasma rico em plaquetas associado às células-tronco mesenquimais no leito das úlceras venosas de uma das pernas. As úlceras da outra perna não receberão o sistema composto por plasma rico em plaquetas associado à células-tronco mesenquimais, atuando como controle, porém sob tratamento convencional oferecido pelo ambulatório. Haverá também uma investigação in vitro

Endereço: Rua Tessália Vieira de Camargo, 126

Bairro: Barão Geraldo

CEP: $13.083-887$

UF: SP Município: CAMPINAS

Telefone: (19)3521-8936

Fax: (19)3521-7187

E-mail: cep@fcm.unicamp.br 


\section{FACULDADE DE CIENCIAS MEDICAS - UNICAMP (CAMPUS CAMPINAS)}

para avaliação da influência de células-tronco mesenquimais e plasma rico em plaquetas sobre células da pele (fibroblastos, queratinócitos e melanócitos)."

\section{Objetivo da Pesquisa:}

Objetivo Primário: Realizar administração tópica de plasma rico em plaquetas associado à células-tronco mesenquimais derivadas do tecido adiposo autólogos em úlceras venosas de membros inferiores.

Objetivo Secundário: Avaliar a segurança, resposta clínica e eficácia da terapia celular proposta, por meio de análise do aspecto e evolução das úlceras venosas, bem como avaliar a influência de células-tronco mesenquimais e PRP sobre células da pele (fibroblastos, queratinócitos e melanócitos) in vitro.

\section{Avaliação dos Riscos e Benefícios:}

Afirma-se que "a abordagem terapêutica proposta neste estudo envolve o emprego clínico de células-tronco mesenquimais oriundas do tecido adiposo e plasma rico em plaquetas(PRP) derivado do sangue, ambos os tipos celulares provenientes do próprio paciente, ou seja, um procedimento integralmente autólogo. Desta forma, não há riscos previsíveis, uma vez que todo o material possui biocompatibilidade com o indivíduo receptor. Uma ressalva,

entrementes, relacionada às más condições de higiene do paciente, pode se tornar realidade e desencadear infecções secundárias no leito da úlcera. Deve-se enfatizar que a possibilidade de infecções não é relacionada ao implante, mas sim à situação de baixa assepsia que o paciente pode vir a expor o sistema composto por úlcera e implante. Com relação aos pacientes que não obtiverem resposta clínica satisfatória concernente à

terapêutica proposta, medidas adequadas, ou seja, o tratamento convencional será instituído. Com o propósito da investigação in vitro, não haverá riscos para os pacientes doadores, constituindo, aliás, materiais de descarte após procedimento cirúrgico bariátrico e de blefaroplastia."

Os benefícios relacionam-se ao potencial terapêutico da intervenção sobre as úlceras venosas.

\section{Comentários e Considerações sobre a Pesquisa:}

A pesquisa se justifica e o projeto de doutorado anexado na plataforma apresenta-se bem escrito e fundamentado.

\section{Considerações sobre os Termos de apresentação obrigatória:}

Foram apresentados os Termos de Consentimento Livre e Esclarecido solicitados, que cumprem os requisitos da Resolução 196/96.

\section{Recomendações:}

Não há.

Endereço: Rua Tessália Vieira de Camargo, 126

Bairro: Barão Geraldo

UF: SP Município: CAMPINAS

Telefone: (19)3521-8936 Fax: (19)3521-7187 E-mail: cep@fcm.unicamp.br 


\section{FACULDADE DE CIENCIAS MEDICAS - UNICAMP (CAMPUS CAMPINAS)}

Conclusões ou Pendências e Lista de Inadequações:

Todas as pendências foram atendidas.

Situação do Parecer:

Aprovado

Necessita Apreciação da CONEP:

Não

Considerações Finais a critério do CEP:

CAMPINAS, 26 de Abril de 2013

Assinador por:

Fátima Aparecida Bottcher Luiz

(Coordenador) 
Aos meus queridos e amados pais, Gerson Stessuk (in memoriam) e Maria Luiza Mazzo Stessuk. Ao amor entre os dois, que me deu a vida e entalhou valores no coração. 


\section{AGRADECIMENTOS}

A Deus, por permitir a vida até aqui.

À minha querida família, sempre presente na hora da angústia e da alegria. Meu pai Gerson Stessuk (in memoriam), meu exemplo de honestidade, humildade e sabedoria. Minha mãe Maria Luiza Mazzo Stessuk, meu exemplo de força, coragem e fé. Minha irmã Nikole Stessuk, que não me deixa desistir.

Aos meus tios Roberto Maschio e Ester Stessuk Maschio, por acreditarem em mim e me apoiarem incondicionalmente. Ao meu primo Andrei Maschio, herói.

Ao Guilherme Elias, meu querido, que trouxe suavidade e doçura no final do trabalho.

Ao Prof. Dr. João Tadeu Ribeiro-Paes por viabilizar a pesquisa e transmitir conhecimentos preciosos.

À Profa. Dra. Maria Beatriz Puzzi pelo acolhimento, viabilização prática da pesquisa e pelo estímulo da resiliência.

Ao querido Paulo César Martins Alves, meu exemplo de justiça e força nos momentos difíceis e à Jussara Rehder pelo companheirismo e conhecimentos transmitidos. À Dra. Paula Tavares Colpas por sua disposição e atendimento aos pacientes.

Aos pacientes e respectivos familiares, razões da pesquisa e motivos de inspiração para a vida.

Ao corpo docente da Faculdade de Ciências Médicas da UNICAMP que, sempre com cordialidade, colaboraram com a pesquisa, em especial a Dra. Carla Aparecida Faccio Bosnardo, Dra. Ana Terezinha Guillaumon, Dr. Eliton Adami Chaim e Dr. Erich Vinícius de Paula. Também a todos os funcionários: médicos, enfermeiras, residentes, secretárias que, sempre com bom ânimo, colaboraram para o trabalho.

Às várias gerações de amigos do Laboratório de Genética e Terapia Celular, pela parceria, motivação e amizade. Também ao corpo docente e funcionários da UNESP Campus de Assis pela disposição e bom ânimo em todos os momentos.

Aos docentes da USP, que colaboraram para o meu aprendizado e motivaram ideias. À Eliane, Fabia e Marcos da Secretaria de Biotecnologia pela paciência, atenção e força.

Ao Fundo de apoio à dermatologia do estado de São Paulo (FUNADERSP) pelo auxílio financeiro concedido para este trabalho e à CAPES pela bolsa de doutorado. Às flores da estação e aos amigos queridos.

Aos erros. 
"Qualquer pessoa é capaz de qualquer coisa, desde que tenha uma oportunidade."

Gerson Stessuk 


\section{RESUMO}

STESSUK, T. Terapia celular em úlceras crônicas com implante de células-tronco mesenquimais associadas a plasma rico em plaquetas. 2016. 142 f. Tese (Doutorado em Biotecnologia) - Instituto de Ciências Biomédicas, Universidade de São Paulo, São Paulo, 2016.

O impacto econômico e social relacionado ao tratamento de úlceras cutâneas crônicas é significante no Brasil e no mundo, bem como é crescente 0 número de pacientes com doenças crônicas sistêmicas, como exemplo o diabetes mellitus, que favorecem o aparecimento e a continuidade de lesões dermo-epidérmicas. Úlceras cutâneas de difícil cicatrização estão sujeitas a uma série de defeitos fisiológicos e bioquímicos que colaboram para a cronicidade das lesões e, conseqüentemente, a baixa eficiência dos tratamentos convencionais e o risco de amputações. No âmbito da medicina regenerativa para o tratamento de lesões cutâneas crônicas, o emprego clínico da bioengenharia de tecidos associada à terapia celular com células-tronco adultas tem sido considerado como uma nova e promissora alternativa terapêutica. Diante da importância fisiológica dos fatores plaquetários durante a cicatrização, o plasma rico em plaquetas (PRP) tem sido utilizado com o propósito da regeneração tecidual e pode atuar como um suporte celular. Atribui-se às células-tronco mesenquimais (CTM) propriedades imunomodulatórias, antinflamatórias, proliferativas, anti-apoptóticas e antifibróticas, que as tornam extremamente interessantes para atuar em processos regenerativos cutâneos. Neste contexto, o estudo tem como objetivo principal avaliar a eficácia terapêutica no tratamento de úlceras cutâneas de pacientes diabéticos, empregando CTM do tecido adiposo (CT-TA) associadas a PRP obtido de sangue autólogo. Uma vertente preliminar do estudo, in vitro, proporcionou a padronização da produção e gelificação do PRP, em conformidade com o propósito cutâneo. Ainda, foi verificada a influência positiva e estimulatória do PRP e do meio condicionado proveniente de CT-TA, sobre a proliferação e migração de fibroblastos e queratinócitos, estágios e tipos celulares cruciais durante o processo de cicatrização cutânea. A pesquisa aplicada foi composta por seis pacientes diabéticos e portadores de úlceras cutâneas crônicas, sem cicatrização significante por, no mínimo, seis meses, nos membros inferiores. Para cada paciente foi produzido um PRP autólogo que, após associação com as CT-TA cultivadas, foi gelificado no formato de uma membrana flexível com as dimensões de cada lesão. $O$ seguimento ambulatorial e fotográfico, pós-aplicação, evidenciou a formação de tecido de granulação a partir da primeira semana após o implante. A reepitelização total ocorreu em 5 das 10 lesões tratadas, sendo o índice de cicatrização médio superior a $70 \%$ após 3 meses da aplicação. Neste contexto, é possível concluir que a terapia com CT-TA associadas a PRP proporciona uma redução na área ulcerosa de lesões cutâneas crônicas em pacientes diabéticos. Os primeiros passos dados por este trabalho colaboram para a evolução da terapia celular no tratamento de úlceras cutâneas de difícil cicatrização.

Palavras-chave: Células-tronco. Dermatologia. Diabetes mellitus. Plaquetas sanguíneas. Terapia biológica. Úlcera cutânea. 


\begin{abstract}
STESSUK, T. Cell therapy in chronic ulcers with implant of mesenchymal stem cells associated with platelet-rich plasma.2016. 142 p. Ph. D. thesis (Biotechnology) - Instituto de Ciências Biomédicas, Universidade de São Paulo, São Paulo, 2016.
\end{abstract}

The economic and social burden related to treatment of chronic cutaneous ulcers are significant in Brazil and worldwide, as well as it is increasing the number of patients with systemic chronic diseases, i.e. diabetes mellitus, which favor the emergence and continuity of dermal-epidermal lesions. Cutaneous ulcers with difficult or lack of wound healing are subjected to several physiological and biochemical defects which contribute to the chronicity of the lesions and consequently the low effectiveness of conventional treatments and risk of amputation. In the context of the regenerative medicine for treatment of cutaneous chronic wounds, the clinical use of tissue bioengineering and cell therapy with adult stem cells has been considered as a new and promising therapeutic alternative. Regarding the physiological importance of the platelets factors during wound healing, the platelet-rich plasma (PRP) has been used for tissue regeneration and can act as a cellular scaffold. It is attributed to mesenchymal stem cells (MSC) immunomodulatory, anti-inflammatory, proliferative, anti-apoptotic and anti-fibrotic properties, which makes those cells extremely interesting to work in skin regenerative processes. In this context, the present study aims to evaluate the therapeutic efficiency, using adipose-derived mesenchymal stem cells (ADSC) associated with PRP obtained from autologous blood, for the treatment of cutaneous ulcers from diabetic patients. A preliminary in vitro component of the study provided the standardization of the production and gelation of PRP in accordance with cutaneous purpose. It has been further verified the positive and stimulatory influence of the PRP and conditioned medium from ADSC on the proliferation and migration of fibroblasts and keratinocytes, considered as crucial phases and key cell types during the skin healing process. Subsequently, the applied research was composed of six diabetic patients with chronic skin ulcers in the lower limbs, without significant healing for at least six months. Autologous PRP was produced and, after association with cultured ADSC, the final product was gelatinized in a shape of flexible membrane with dimensions of each lesion size. The photographic and clinical follow up showed the formation of granulation tissue starting from the first week after implantation. The total re-epithelialization occurred in 5 of the 10 lesions treated, and the average wound healing index was greater than $70 \%$ after 3 months of application. In this context, it can be concluded that ADSC therapy associated with PRP provides a reduction in ulcer area of chronic skin lesions in diabetic patients. First steps given in this work collaborate to the evolution of the cell therapy on the treatment of chronic cutaneous ulcers.

Keywords: Biological therapy. Cutaneous ulcers. Dermatology. Diabetes mellitus. Platelet. Stem cells. 


\section{LISTA DE ILUSTRAÇÕES}

Figura 1 - Esquema ilustrativo da anatomia da pele humana ....................... 22

Figura 2 - Esquemas representativos do processo de cicatrização ............... 33

Figura 3 - Processamento da unidade de sangue total para obtenção da fração plasmática e criopreservação

Figura 4 - Obtenção de PRP por meio de uma etapa de centrifugação. ........ 57

Figura 5 - Obtenção de PRP por meio de duas etapas de centrifugação. ..... 58

Figura 6 - Metodologia para isolamento das CT-TA. ................................. 61

Figura 7 - Etapas metodológicas para obtenção de fibroblastos e queratinócitos a partir de fragmentos de pele. ..............................................6 65

Figura 8 - Delineamento experimental do estudo clínico relativo à terapia celular em úlceras cutâneas crônicas com implantes de CT-TA associadas a PRP. 68

Figura 9 - Coleta do tecido adiposo. 71

Figura 10 - Gelificação do PRP após adição de gluconato de cálcio. 79

Figura 11 - Volumes da fração líquida obtida durante contração do gel de PRP ativado em diferentes proporções de gluconato de cálcio a 10\%.

Figura 12 - Aspecto morfológico de CT-TA verificado por microscopia de contraste de fase.

Figura 13 - Caracterização imunofenotípica das CT-TA por citometria de fluxo com diferentes marcadores de membrana.

Figura 14 - Diferenciação adipogênica das CT-TA. ................................... 82

Figura 15 - Diferenciação condrogênica das CT-TA. .................................. 83

Figura 16 - Diferenciação osteogênica das CT-TA. ……………………....... 83

Figura 17 - Crescimento de CT-TA cultivadas em diferentes concentrações de PRP em comparação com $10 \%$ de SFB e meio de cultura sem suplemento (branco). 84

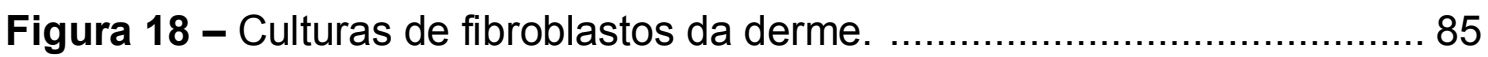

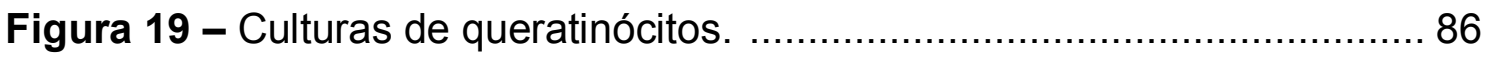


Figura 20 - Crescimento de fibroblastos e queratinócitos cultivados em diferentes concentrações de PRP.

Figura 21 - Crescimento de fibroblastos e queratinócitos cultivados em diferentes concentrações de MC derivado de CT-TA. ................................ 88

Figura 22 - Crescimento de fibroblastos e queratinócitos cultivados em diferentes concentrações de PRP e MC derivado de CT-TA. ........................ 89

Figura 23 - Ensaio de migração de CT-TA. ............................................... 90

Figura 24 - Ensaio de migração de fibroblastos da derme cultivados com meio condicionado de CT-TA e PRP.

Figura 25 - Aspecto morfológico das CT-TA dos pacientes submetidos à terapia.

Figura 26 - Diferenciação adipogênica das CT-TA dos pacientes submetidos à terapia.

Figura 27 - Diferenciação condrogênica das CT-TA dos pacientes submetidos à terapia. 95

Figura 28 - Diferenciação osteogênica das CT-TA dos pacientes submetidos à terapia. 96

Figura 29 - CT-TA imersas no gel de PRP. 98

Figura 30 - Cultivo in vitro de CT-TA imersas no gel de PRP. 98

Figura 31 - Variação da área ulcerosa para cada lesão no seguimento de 90 dias. 100

Figura 32 - Medidas, em $\mathrm{cm}^{2}$, de cada lesão pré-tratamento e 90 dias após o início da terapia 101

Figura 33 - Processo de cicatrização de uma lesão trófica na região dorsal do pé esquerdo (Paciente I) 102

Figura 34 - Processo de cicatrização de duas lesões tróficas (Paciente V).. 103

Figura 35 - Diferença entre lesões pequenas e grandes quanto aos índices de cicatrização obtidos após 90 dias de tratamento com CT-TA e PRP 104

Figura 36 - Correlação entre o número de CT-TA (imersas no gel de PRP) aplicadas por $\mathrm{cm}^{2}$ de área ulcerosa e os índices de cicatrização obtidos após 90 dias do implante em úlceras crônicas de pacientes diabéticos 105 


\section{LISTA DE TABELAS}

Tabela 1 - Citocinas, células secretoras e principais funções durante a cicatrização

Tabela 2 - Proteínas, enzimas e fatores de coagulação encontrados nos $\alpha$ grânulos plaquetários e respectivas funções.

Tabela 3 - Biomoléculas encontradas nos grânulos densos das plaquetas e respectivas funções 39

Tabela 4 - Protocolos de centrifugação para obtenção do PRP. 56

Tabela 5 - Distribuição dos pacientes quanto ao gênero, fototipo, antecedentes mórbidos e número de lesões.

Tabela 6 - Concentrações das frações celulares e plaquetárias em seis protocolos testados para obtenção de PRP $(n=3)$.

Tabela 7 - Médias $(n=3)$ das eficiências de recuperação do plasma e das plaquetas obtidos por diferentes protocolos.

Tabela 8 - Valores de pH obtidos após ativação plaquetária com diferentes proporções de gluconato de cálcio a $10 \%$ para cada $1 \mathrm{~mL}$ de PRP.

Tabela 9 - Médias dos valores de absorbância $(n=6)$ obtidos após 24 e 48 horas para cada grupo de CT-TA cultivadas em diferentes concentrações de PRP.

Tabela 10 - Médias dos valores de absorbância $(n=6)$ obtidos após 24 e 48 horas por cada grupo de fibroblastos cultivados em diferentes concentrações de PRP e MC.

Tabela 11 - Médias dos valores de absorbância ( $n=6)$ obtidos após 24 e 48 horas por cada grupo de queratinócitos cultivados em diferentes concentrações de PRP e MC.

Tabela 12 - Médias $(\mathrm{n}=9)$ das porcentagens relativas às áreas ocupadas por CTM derivadas do tecido adiposo em migração após 24 e 48 horas sob a influência de PRP em comparação com $10 \%$ de SFB e meio de cultura sem suplemento (branco).

Tabela 13 - Médias $(n=9)$ das porcentagens relativas às áreas ocupadas por fibroblastos em migração após 24 e 48 horas sob a influência de diferentes concentrações de PRP e MC, em comparação com $10 \%$ de SFB e meio de cultura sem suplemento (branco). 
Tabela 14 - Caracterização imunofenotípica das CT-TA dos pacientes submetidos à terapia.

Tabela 15 - Concentrações das frações celulares e plaquetárias no sangue total e no PRP de cada paciente.

Tabela 16 - Eficiências na recuperação de plasma e plaquetas obtidos com o processamento do sangue total para produção do PRP de cada paciente. .... 97

Tabela 17 - Relação dos pacientes e características gerais das úlceras. ...... 99

Tabela 18 - Valores absolutos das áreas ulcerosas obtidas durante o seguimento ambulatorial de cada paciente submetido à terapia. 100

Tabela 19 - Índices de cicatrização (IC) obtidos durante o seguimento ambulatorial de cada úlcera por paciente submetido à terapia. 101 


\section{LISTA DE ABREVIATURAS}

ANOVA: Análise de variância

bFGF: basic fibroblast growth factor

CCK-8: Cell counting kit-8

CCL-2: Quimiocina CC ligante 2

CPDA-1: Anticoagulante citrato, fosfato, dextrose e adenina

CSF: Colony stimulating factor

CTA: Células-tronco adultas

CTE: Células-tronco embrionárias

CTM: Células-tronco mesenquimais

CT-TA: Células-tronco mesenquimais derivadas do tecido adiposo

DMSO: Dimetilsulfóxido

DPBS: Dulbecco's phosphate-buffered saline

ECGF: Endothelial cell growth factor

EGF: Epidermal growth factor

EGFP: Enhanced green fluorescent protein

$E_{(p l) p s:}$ Eficiência de recuperação do plasma

$E_{(\mathrm{pt}) \text { PRP: }}$ Eficiência da recuperação plaquetária

$F_{\mathrm{CP}}$ : Fator de concentração plaquetária

FDA: Food and drug administration

FGF: Fibroblast growth factor

FVE: Fração vascular estromal

HBEGF: Heparin-binding EGF-like growth factor

H: Hematócrito

HAS: Hipertensão arterial sistêmica

HIV: Human immunodeficiency virus

HTLV: Human T-lymphotropic virus 
IC: Índice de cicatrização

ICU: Índice de cicatrização das úlceras

IGF: Insulin growth factor

IL-1: Interleucina-1

IL-6: Interleucina-6

IL-10: Interleucina-10

KGF: Keratinocyte growth factor

MC: Meio condicionado

mTOR: quinase alvo da rapamicina

$\boldsymbol{N}_{(\mathrm{pt}) \mathrm{ST}}$ : Concentração de plaquetas no sangue total

PC: Primeira centrifugação

PDGF: Platelet derived growth factor

PI3K/AKT: fosfatidilinosito-3-quinase

PMP: Plasma médio em plaquetas

PPP: Plasma pobre em plaquetas

PRP: Plasma rico em plaquetas

PS: Plasma sobrenadante

SC: Segunda centrifugação

SFB: Soro fetal bovino

SFM: Serum free medium

ST: Sangue total

TCLE: Termo de consentimento livre e esclarecido

TGF-a: Transforming growth factor alpha

TGF- $\beta$ : Transforming growth factor beta

TGF- $\beta 1$ : Transforming growth factor beta-1

TGF-ק3: Transforming growth factor beta-3

TIMP-4: Tissue inhibitor of metalloproteinase-4 
TNF- $\alpha$ : Tumor necrosis factor- $\alpha$

VEGF: Vascular endotelial growth fator

$V_{(\text {pl)PRP: }}$ Volume de plasma rico em plaquetas obtido após centrifugação

$V_{(\mathrm{pl)Ps}}$ : Volume do plasma

$V_{(\mathrm{pl}) \mathrm{sT}}$ : Volume de plasma no sangue total

$V_{\mathrm{ST}}$ : Volume de sangue total 
1 INTRODUÇÃO

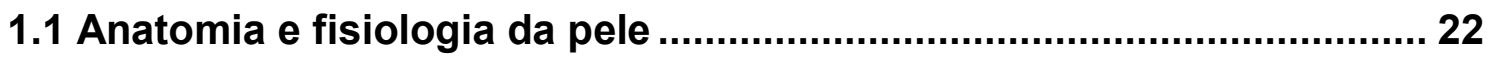

1.2 Úlceras cutâneas crônicas ................................................................... 27

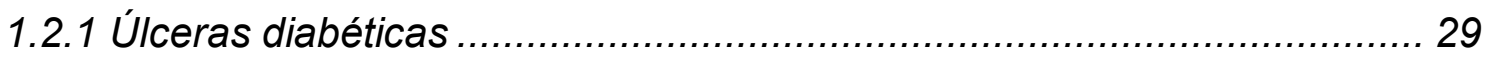

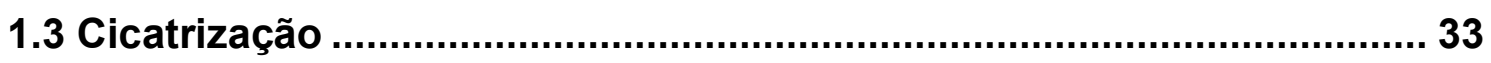

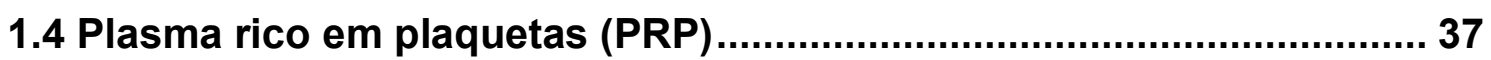

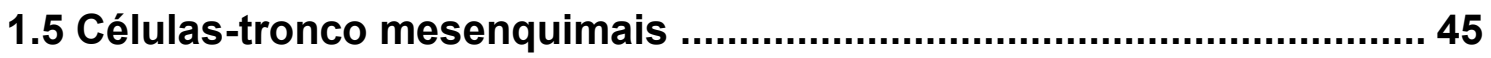

2 OBJETIVOS

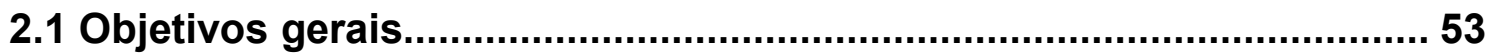

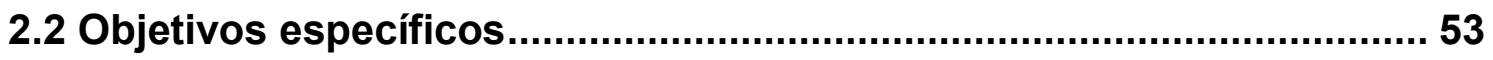

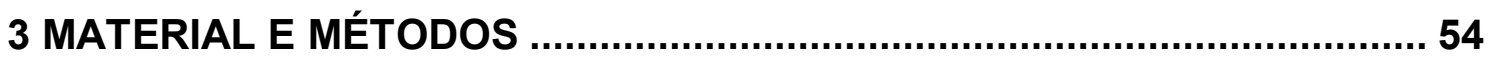

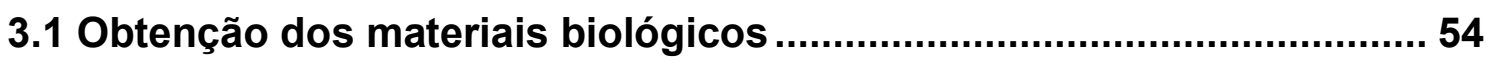

3.1.1 Obtenção e criopreservação do PRP .................................................. 54

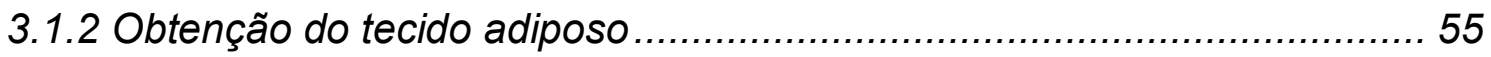

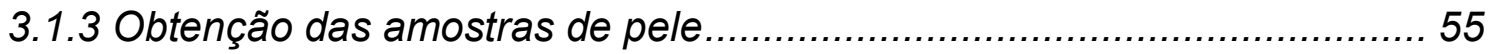

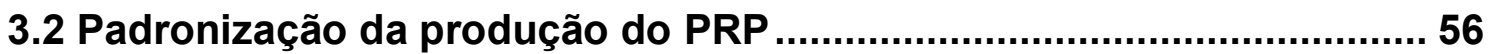

3.2.1 Avaliação dos protocolos de centrifugação ............................................ 56

3.2.2 Quantificação dos componentes sanguíneos...................................... 58

3.2.3 Eficiência na recuperação do plasma e das plaquetas............................ 58

3.3 Padronização da produção do PRP em gel........................................... 59

3.3.1 Avaliação do pH após ativação plaquetária.......................................... 59

3.3.2 Ensaio da formação de gel (gelificação) .............................................. 59

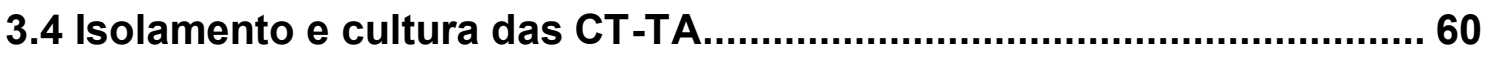

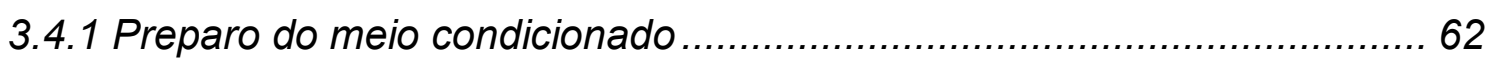

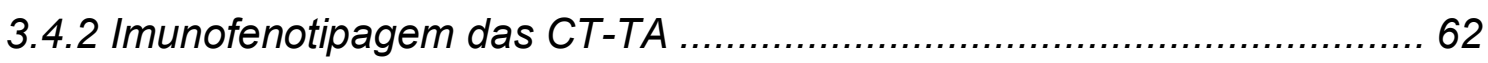

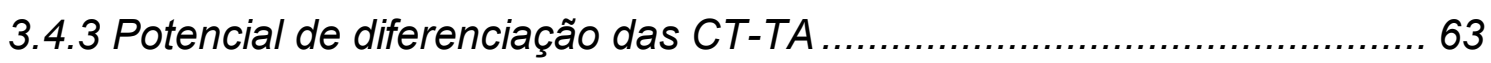

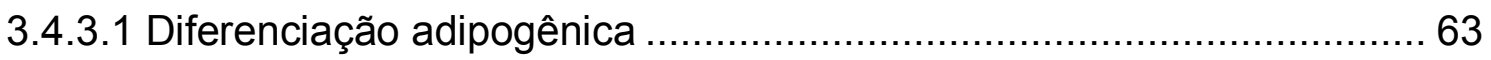

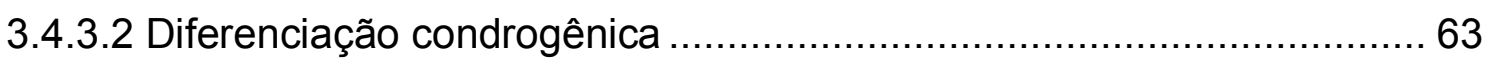

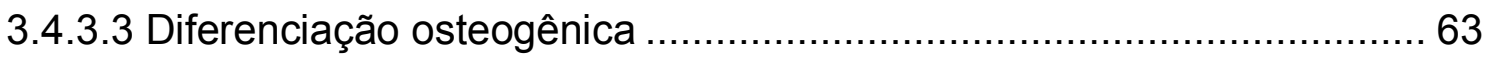

3.5 Isolamento e cultura de fibroblastos e queratinócitos .......................... 64

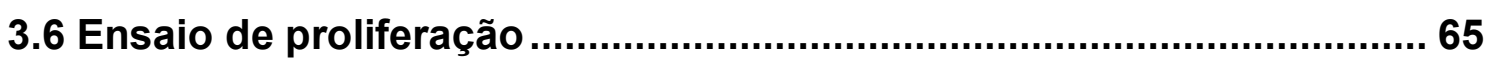

3.7 Avaliação da proliferação de CT-TA na presença de PRP .................... 66 
3.8 Avaliação da proliferação de células de pele na presença de PRP e

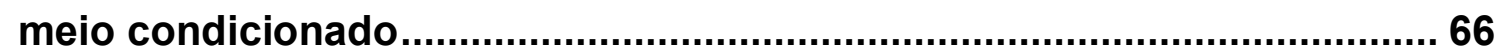

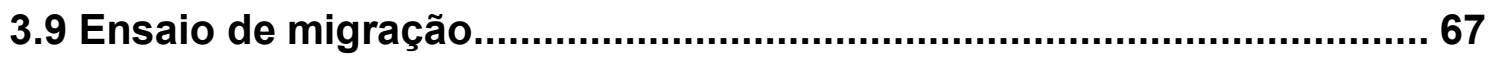

3.10 Desenho experimental do estudo clínico ......................................... 67

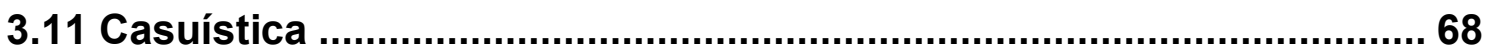

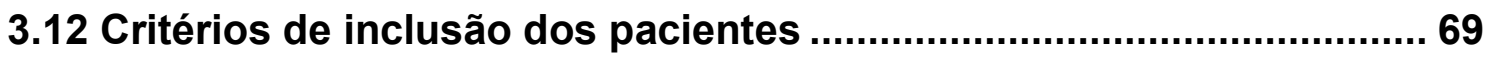

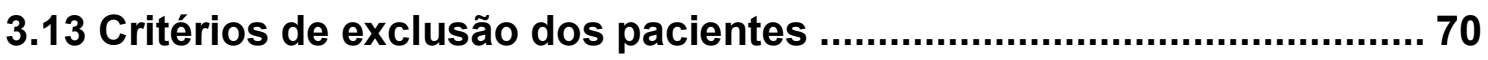

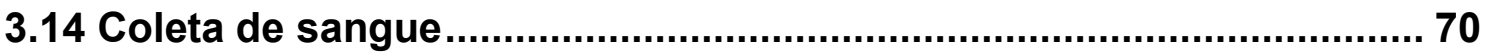

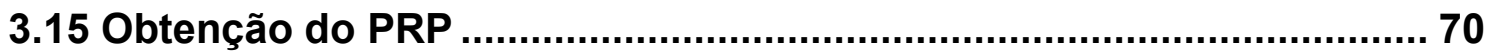

3.16 Coleta, processamento e cultura das CT-TA do pacientes submetidos

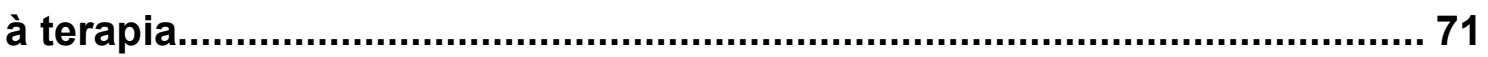

3.17 Controle de qualidade das células................................................. 72

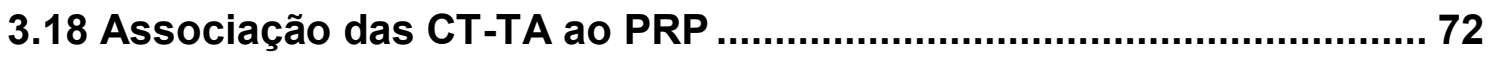

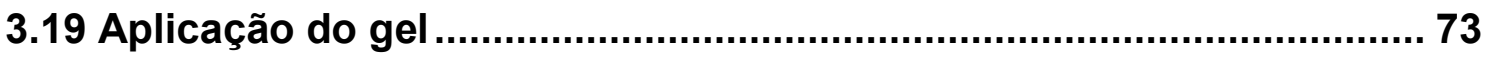

3.20 Evolução clínica e seguimento dos pacientes................................... 75

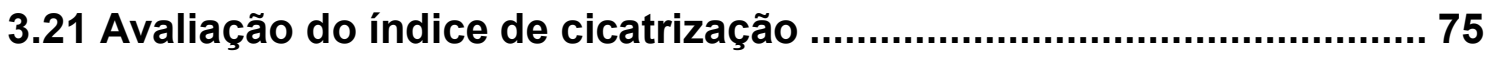

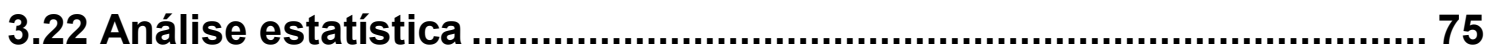

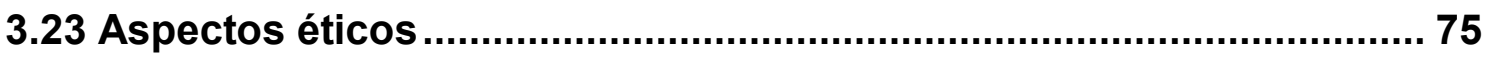

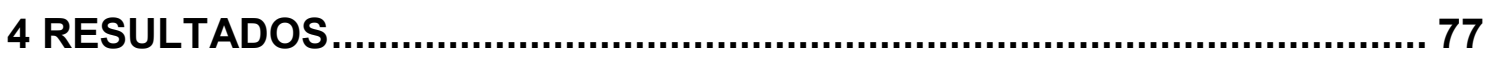

4.1 Padronização da metodologia para produção do PRP ......................... 77

4.2 Análise do pH após ativação plaquetária ................................................ 78

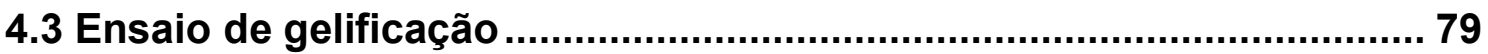

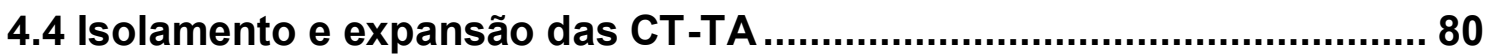

4.5 Imunofenotipagem por citometria de fluxo das CT-TA ......................... 81

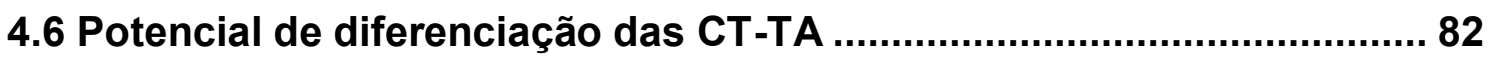

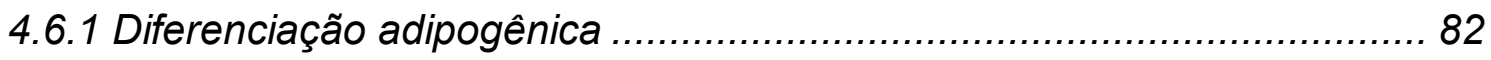

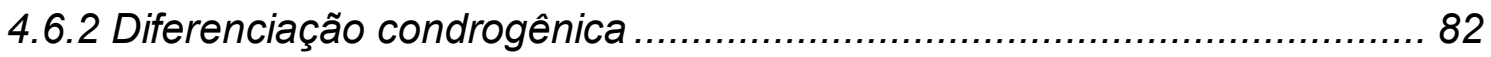

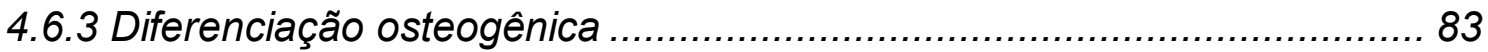

4.7 Ensaio de proliferação das CT-TA na presença de PRP....................... 83

4.8 Isolamento e proliferação das células da pele ..................................... 85

4.9 Ensaio de proliferação das células da pele na presença de PRP e meio

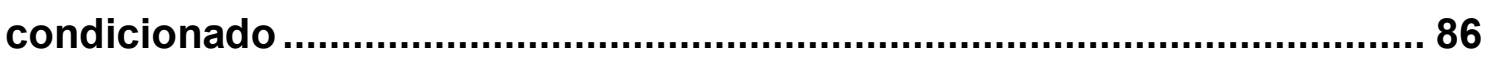

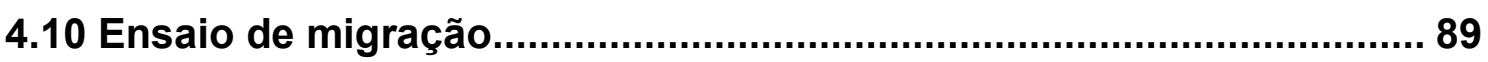


4.11 Isolamento, cultivo e caracterização das CT-TA para aplicação

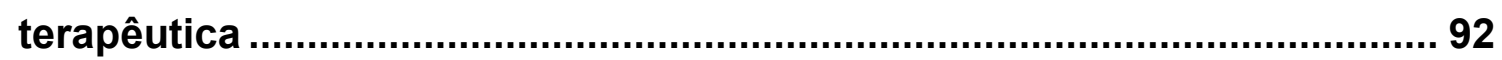

4.12 Citometria de fluxo das CT-TA para aplicação terapêutica ................. 93

4.13 Diferenciação multipotencial das CT-TA dos pacientes submetidos à

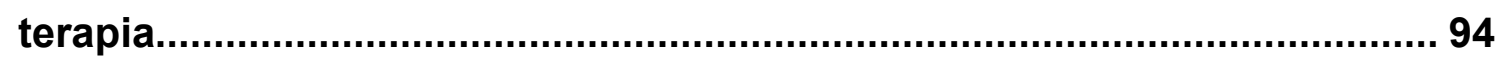

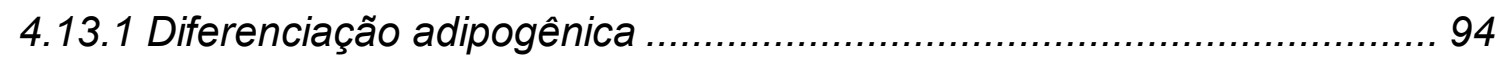

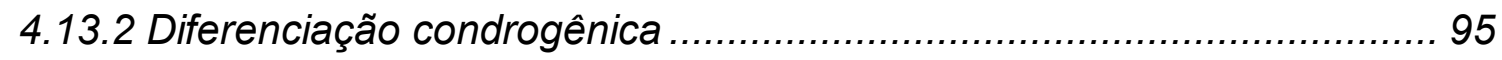

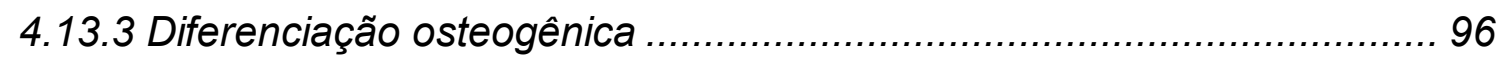

4.14 Caracterização do PRP utilizado na terapia .......................................... 96

4.15 Verificação da associação das CT-TA ao gel de PRP ........................ 98

4.16 Relação das úlceras, localização e cronicidade .................................. 99

4.17 Evolução da cicatrização das úlceras pós-tratamento ........................ 99

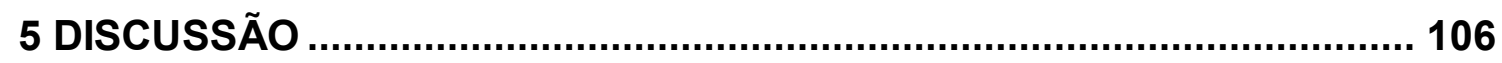

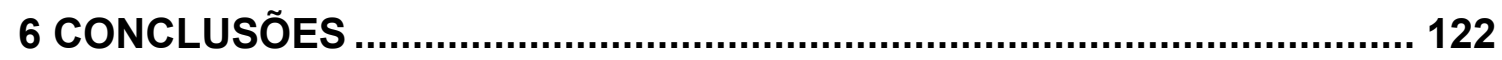

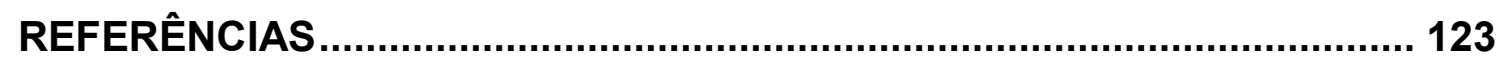

ANEXOS

A - Termo de Consentimento Livre e Esclarecido ................................... 134

B - Termo de Consentimento Livre e Esclarecido .................................. 136

C - Termo de Consentimento Livre e Esclarecido ................................... 138

D - Termo de Consentimento Livre e Esclarecido .................................. 140 


\section{INTRODUÇÃO}

\subsection{Anatomia e fisiologia da pele}

A pele é o órgão mais extenso do ser humano, representando cerca de $15 \%$ do peso corporal e uma dimensão que, no adulto, varia entre $1,5 \mathrm{a} 2 \mathrm{~m}^{2}$. O revestimento cutâneo contém aproximadamente $1 \times 10^{11}$ células de origem mesenquimal, epitelial e neural que, de forma harmônica e bem organizada, constituem a primeira barreira do indivíduo em relação ao ambiente externo, de modo a proporcionar proteção mecânica contra agentes químicos, físicos e microbiológicos, nocivos ao organismo (SAMPAIO; RIVITTI, 2007). A pele, portanto, é um órgão complexo e formado por unidades morfo-funcionais conectadas e interdependentes, responsáveis pela regulação e modulação da estrutura molecular, celular e tecidual.

Quanto à organização tecidual, a pele é classicamente dividida em três camadas principais: epiderme, derme e hipoderme, em acordo com o esquema ilustrado na Figura 1. A epiderme, primeira e mais externa, é formada por epitélio estratificado pavimentoso queratinizado e tem origem ectodérmica. Os tipos celulares epidermais são os melanócitos, células de Langerhans e células de Merkel, porém, majoritariamente, queratinócitos. Os diferentes tipos celulares podem distribuir-se entre 3 e 5 camadas dentro da epiderme, dependendo da espessura epitelial,que pode variar de 0,4 $\mathrm{mm}$ nas pálpebras a 1,6 mm nas áreas palmo-plantares (JUNQUEIRA; CARNEIRO, 2008).

Figura 1 - Esquema ilustrativo da anatomia da pele humana.

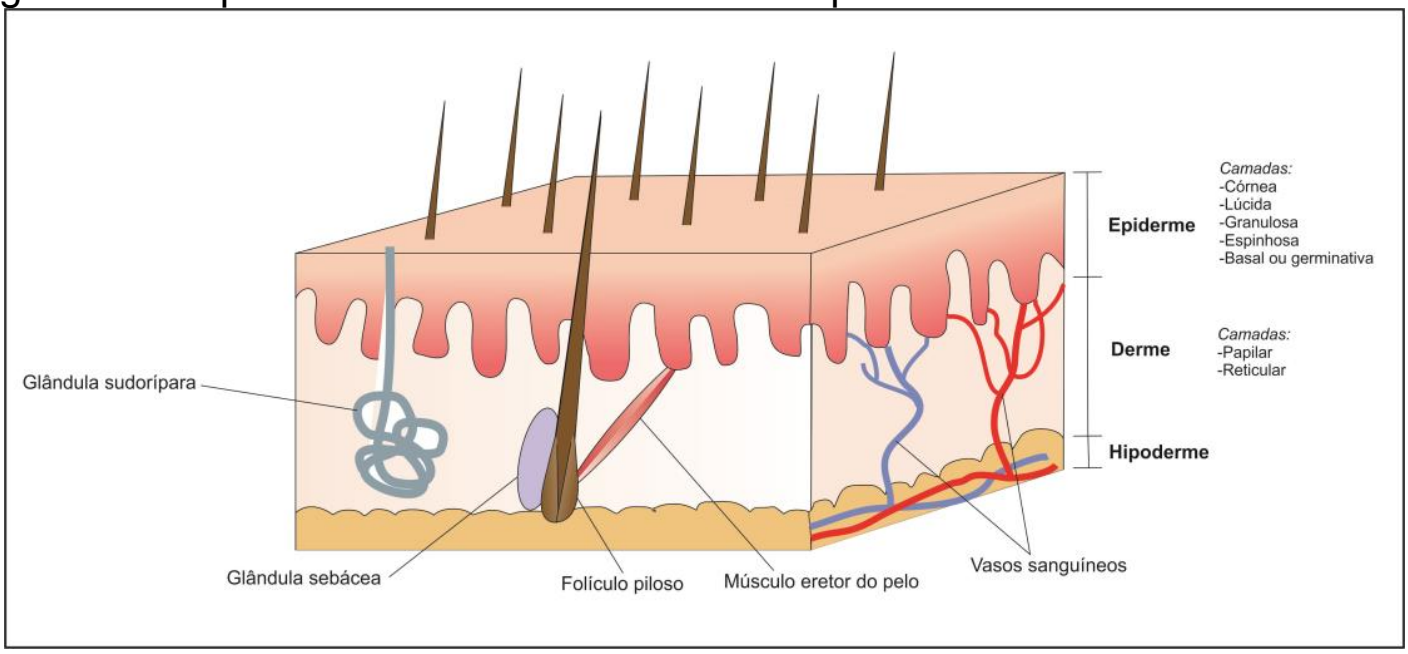


Da região epidermal mais profunda até a superfície, estão a camada basal ou germinativa (com células progenitoras, células-tronco da epiderme e intensa atividade mitótica), espinhosa (com células progenitoras dos queratinócitos), granulosa, lúcida e córnea (SAMPAIO; RIVITTI, 2007).

A camada basal, ou estrato germinativo, é responsável pela origem das demais camadas epidermais. Apresenta células progenitoras, melanócitos esparsos e queratinócitos em formato colunar. A intensa atividade mitótica da camada basal proporciona a constante renovação da epiderme (a cada 28 dias). Com o passar do tempo, os queratinócitos com origem na camada basal, vão se diferenciando e migrando em direção à camada córnea e, deste modo, as características de cada camada epidérmica são o reflexo do estágio de diferenciação, mitose e propriedades sintéticas dos queratinócitos ( $\mathrm{CHU}$ et al., 2003).

Os queratinócitos representam cerca de $80 \%$ das células epidermais e tem, como função principal, a produção de queratina, proteína flexível e elástica que atua como barreira contra agentes externos na camada córnea. Desta forma, todos os queratinócitos contém filamentos intermediários de queratina citoplasmática e formam desmossomos com células adjacentes, mantendo coesas as camadas epidérmicas e conferindo resistência ao atrito (JUNQUEIRA; CARNEIRO, 2008). Com o propósito da renovação epidérmica, os queratinócitos sofrem modificações morfológicas e metabólicas até o estágio final do processo de queratinização, o corneócito, que corresponde a um queratinócito morto, anucleado, completamente diferenciado, repleto de filamentos de queratina e com a membrana plasmática associada a lipídeos de superfície (CHU et al., 2003).

Ainda na camada basal, porém em quantidade inferior aos queratinócitos (1:36), são encontrados os melanócitos, células dendríticas derivadas da crista neural e produtoras de pigmento. Os melanócitos produzem, via melatogênese, a melanina, pigmento ligado à coloração da pele e à proteção contra radiação solar. A melanina, confinada nos melanossomos, é transferida para os queratinócitos e, por esta forma, para a camada basal e, em menor extensão, para as camadas superficiais. Os queratinócitos ainda produzem fatores de crescimento mitóticos para os melanócitos, tais como o fator de crescimento de 
fibroblasto básico (basic fibroblast growth factor - bFGF) e o fator de crescimento transformante alfa (transforming growth factor alpha - TGF- $\alpha$ ), mas também a diferenciação melanocítica é influenciada por ação hormonal, inflamatória e pela vitamina D (SAMPAIO; RIVITTI, 2007).

Imediatamente acima da camada basal, a camada espinhosa, conhecida também como corpo mucoso de Malphigi, é formada por poucas fileiras de células cuboides ou ligeiramente achatadas. Pequenas modificações na superfície das células e a abundância de desmossomos conferem o aspecto espinhoso e proporcionam proteção contra o estresse mecânico. Ainda, os queratinócitos mais superficiais da camada espinhosa contêm grânulos lamelares, repletos de precursores lipídicos da camada córnea, bem como glicoproteínas e diversas enzimas que possuem também uma função lisossomal, além da propriedade secretora (CHU et al., 2003).

A camada intermediária, ou granulosa, é caracterizada por possuir os elementos necessários para o processo de apoptose e para a formação de uma barreira impermeável à água. No interior dos queratinócitos, há grânulos de querato-hialina, formados por filamentos intermediários de queratina e profilagrina, bem como grânulos lamelares, responsáveis pela impermeabilização da pele a líquidos, em geral, devido ao seu conteúdo lipídico. Embora presentes na camada espinhosa, os grânulos lamelares têm o sítio de ação entre a camada granulosa e a camada córnea, onde o conteúdo granular é liberado no espaço intercelular para compor uma barreira lipídica impermeável. A camada lúcida, praticamente inexistente nas regiões palmoplantares, possui uma grande quantidade de eleidina, responsável pelo tom translúcido da pele (BOSNARDO, 2010; SAMPAIO; RIVITTI, 2007).

Finalmente, a camada córnea é a mais superficial da pele e possui queratinócitos mortos e anucleados, completamente diferenciados e repletos de queratina, filagrina e enzimas (JUNQUEIRA; CARNEIRO, 2008). As células são poliédricas, achatadas e em constante descamação, sendo a estrutura lamelar formada basicamente por colesterol, ceramidas e ácidos graxos livres. A camada córnea, portanto, é responsável pela proteção mecânica e atua como uma barreira que previne a perda de água e a permeação de moléculas solúveis provenientes do ambiente externo (SAMPAIO; RIVITTI, 2007). 
A proteção imunológica da pele é conferida, primariamente, às células de Langerhans, localizadas nas camadas suprabasais e responsáveis pelo reconhecimento, processamento e apresentação de antígenos aos linfócitos $\mathrm{T}$. Já a sensibilidade tátil é percebida pelas células de Merkel, entre os queratinócitos, que atuam como mecanorreceptores e secretam transmissores químicos em sinapses diretas com terminações nervosas. Todas as interações e comunicações das células epidérmicas, bem como o controle do número de células, diferenciação e apoptose, são regulados por fatores de crescimento, citocinas, hormônios e neuropeptídios que atuam de maneira coordenada para a manutenção da homeostasia cutânea. Ainda, a epiderme pode ser influenciada pelo tecido conjuntivo subjacente, a fim de manter a estrutura e função da pele (CHU et al., 2003; SAMPAIO; RIVITTI, 2007).

Contígua ao estrato germinativo, a junção dermo-epidérmica, onde está inserida a lâmina basal, delimita a divisão entre a epiderme e a derme, proporcionando adesão entre as duas camadas da pele e proteção contra forças mecânicas externas. Já a derme proporciona e colabora para a elasticidade, resistência à tração e maleabilidade da pele, bem como previne a perda de água, auxilia na termorregulação e protege o organismo de agressões mecânicas (JUNQUEIRA; CARNEIRO, 2008).

A camada dérmica contém papilas dérmicas, compostas por fibrilas especiais de colágeno (principal constituinte), fibras elásticas, vasos sanguíneos, nervos, e anexos epidérmicos: glândulas sebáceas, sudoríparas e folículos pilosos. Também, outros tipos celulares como mastócitos, macrófagos, linfócitos, células do plasma e diferentes tipos de leucócitos migram até a camada dérmica em resposta a estímulos. Os fibroblastos, tipo celular mais abundante da derme, promovem a interação derme-epiderme e são responsáveis por estruturar a matriz extracelular. Essas células de origem mesenquimal sintetizam mediadores solúveis e proteínas fibrosas e não fibrosas da matriz, além de que podem migrar pelo órgão cutâneo entre os feixes de fibras. Dentre esses mediadores encontram-se os componentes da matriz extracelular como proteínas colágeno, elastina, glicosaminoglicanos, proteoglicanos, glicoproteínas multiadesivas e citocinas (KIM et al., 2007). 
A derme é dividida em duas regiões: papilar e reticular, sendo as diferenças de cada região relacionadas à organização tecidual, densidade celular e disposição dos vasos e nervos. A derme papilar é mais próxima da epiderme, possui fibroblastos com alta atividade metabólica e pequenos feixes de fibrilas delicadas de colágeno. Já a derme reticular é a região predominante e abriga largos feixes de fibrilas espessas de colágeno circundadas por fibras elásticas. A divisão entre as duas regiões dérmicas é marcada por um plexo venoso subpapilar (JUNQUEIRA; CARNEIRO, 2008).

A camada dérmica é ricamente vascularizada, sendo as paredes dos vasos mais espessas do que as encontradas em outros órgãos, devido à possibilidade de agressões externas e, ainda, suportadas por tecido conjuntivo e células musculares. A vasculatura cutânea suporta a camada epidérmica e contribui em processos de cicatrização e eventos imunológicos, além de regular a temperatura e pressão sanguínea (CHU et al., 2003).

Sensações em resposta a estímulos transmitidos à pele, como dor, calor, coceira e tato, são captadas por fibras sensoriais em terminações nervosas livres ou em conjunto com receptores corpusculares ao longo de toda a superfície cutânea. Largos ramos de nervos músculo-cutâneos mielinizados surgem dos nervos espinhais, sendo a diversidade de fibras nervosas distribuídas pela derme em acordo com a funcionalidade (SAMPAIO; RIVITTI, 2007).

Por fim, abaixo da derme reticular, uma transição abrupta entre o tecido conjuntivo, predominantemente fibroso, e a região subcutânea rica em tecido adiposo, marca o início da hipoderme. Formada por tecido conjuntivo frouxo,a hipoderme é composta principalmente por adipócitos organizados em lóbulos definidos por septos de tecido conjuntivo fibroso (JUNQUEIRA; CARNEIRO, 2008). O panículo adiposo é variável e atua como reserva de energia e isolamento térmico, além de proteger o organismo e permitir a mobilidade da pele em relação aos órgãos subjacentes.

Indubitável e obviamente, a pele é de fundamental importância para a proteção do organismo humano. Porém, muitas vezes este órgão torna-se vulnerável às agressões externas e alterações patológicas de órgãos internos como pâncreas (diabetes mellitus) e fígado (cirrose), que se expressam de 
forma multissistêmica, repercutindo, também em manifestações clínicas dermatológicas, entre as quais, as úlceras cutâneas crônicas de difícil cicatrização.

\section{2 Úlceras cutâneas crônicas}

As lesões cutâneas crônicas representam um sério problema de saúde pública em escala global. Os dados epidemiológicos, em especial a incidência e prevalência de úlceras cutâneas crônicas, são escassos e não esclarecedores, uma vez que não há um consenso sobre a definição de uma "lesão crônica" e as referências são, na maioria dos trabalhos, de regiões geográficas específicas, subestimadas ou ainda subnotificadas (GOULD et al., 2015). Contudo, o aumento da idade está diretamente relacionado ao aumento na incidência de úlceras crônicas e a morbidade em pacientes com doenças sistêmicas e/ou circulatórias, especialmente nos membros inferiores (MARKOVA; MOSTOW, 2012). Desta forma, considerando o aumento na expectativa de vida da população, continuamente exposta e associada a fatores de risco como tabagismo e obesidade, é crescente o ônus econômico destinado para o tratamento e complicações clínicas decorrentes de lesões cutâneas de difícil cicatrização.

As úlceras cutâneas englobam lesões cirúrgicas, úlceras de pressão, úlceras de pé diabético (secundárias ao diabetes) e úlceras venosas de perna. Úlceras cutâneas crônicas podem ser definidas como lesões em que a epiderme e, pelo menos a parte superficial da derme, estão afetadas por uma descontinuidade, durante, pelo menos, 4 semanas (SHAI; MAIBACH, 2005).

Vários são os fatores, locais e sistêmicos, que compõem a etiopatogênese das úlceras cutâneas crônicas e colaboram para a estagnação das lesões em uma ou mais fases do processo normal de cicatrização. A presença de infecções, isquemia, toxinas, radiações, traumas e insuficiência arterial/venosa constituem fatores locais que dificultam 0 processo regenerativo. Doenças sistêmicas crônicas, tabagismo, alcoolismo, drogas, deficiência nutricional e o envelhecimento são também capazes de comprometer o fechamento de lesões cutâneas (AMATO et al., 2015). A 
etiologia relacionada às doenças crônicas das úlceras de perna é constituída por diabetes mellitus, doenças dermatológicas, hematológicas, reumáticas e vasculares (BOSNARDO, 2010).

O processo ótimo de regeneração é dependente de uma integração coordenada entre o complexo biológico e eventos moleculares de migração e proliferação, bem como a adequada deposição e remodelamento da matriz extracelular com o propósito final da cicatrização total (MEHENDALE; MARTIN, 2001). Contudo, a cicatrização e proliferação celular estão prejudicadas nas úlceras crônicas, em virtude do comprometimento relativo à integridade da matriz dérmica, sendo esta a grande reguladora celular e da atividade de citocinas (WONG; GURTNER, 2012). Deste modo, os fibroblastos que deveriam sofrer proliferação e secretar colágeno no local da lesão não são estimulados pela matriz morfo-funcionalmente comprometida e, conseqüentemente, não há resolução do processo cicatricial.

A ausência de suporte para a proliferação epidérmica impede ainda outro papel essencial de fibroblastos e queratinócitos: a contração do leito da ferida (ISAAC et al., 2011). Isso pode ser explicado pelo controle do queratinócito na transformação fenotípica do fibroblasto em miofibroblasto, em um meio ambiente pró-inflamatório ou de predomínio do fator de crescimento transformante beta (transforming growth factor beta - TGF- $\beta$ ) (WERNER; KRIEGER; SMOLA, 2007).

As úlceras crônicas são caracterizadas ainda pela continuidade da fase inflamatória e a marcante presença de neutrófilos produtores de enzimas. Níveis aumentados de citocinas pró-inflamatórias, metaloproteinases, colagenase, elastase e níveis reduzidos de fatores de crescimento caracterizam as lesões cutâneas de caráter crônico, em especial as úlceras diabéticas e venosas (AMATO et al., 2015).

As práticas terapêuticas clássicas e convencionais, todavia, resultam muitas vezes ineficazes ou meramente paliativas. Ainda que, sob condições favoráveis, o processo de reparo desencadeia fibrose e cicatrizes (HAlHONG; XIAOBING, 2012). Estratégias mais modernas utilizam hidrogeis, que se constituem em terapias com maior resolutividade, porém com custo mais elevado. Perspectivas para a próxima geração de abordagens clínicas, em 
úlceras cutâneas crônicas, englobam delineamentos experimentais provenientes da medicina regenerativa. Como exemplo, o emprego da terapia celular e bioengenharia tecidual (BOSNARDO, 2010), com o propósito de otimizar a cicatrização das úlceras cutâneas.

Neste contexto, a tendência atual que se apreende da literatura envolve a pesquisa por estratégias terapêuticas eficazes para acelerar o processo de cicatrização, bem como otimizar a reepitelização em pacientes portadores de úlceras cutâneas crônicas. Abordagens que diminuam o tempo de tratamento e complicações secundárias, assim como possibilitem intensa recuperação morfológica e funcional da pele são de extremo interesse clínico. Em todas essas situações, deve-se considerar como prioridades fundamentais o baixo custo, segurança para o paciente e reconhecida eficácia via adequado reparo da lesão.

\subsection{1 Úlceras diabéticas}

A incidência global do diabetes mellitus cresce em proporções epidêmicas (WILD et al., 2004). No Brasil, 7,6\% da população, entre 30 e 69 anos, é acometida pelo diabetes mellitus, sendo que 50\% desconhecem o diagnóstico e $24 \%$ não realizam qualquer tipo de tratamento (MALERBI; FRANCO, 1992; OLIVEIRA; VENCIO, 2015). A morbidade e mortalidade dos pacientes diabéticos estão também associadas às complicações secundárias, como a hipertensão arterial sistêmica (HAS), nefropatia diabética (ND), retinopatia diabética (RD) e ainda lesões ulcerosas de caráter crônico, especialmente nos membros inferiores.

Pequenos traumas, dermatoses comuns ou manipulações impróprias dos pés desencadeiam o aparecimento de úlceras cutâneas de difícil cicatrização em pacientes diabéticos. Estima-se que 12 a $25 \%$ dos pacientes com diabetes mellitus desenvolvem úlceras cutâneas nos pés ao longo da vida. Considerável preocupação é associada ao risco de amputação, uma vez que 85\% das úlceras precedem amputações (BREM et al., 2006).

A prevalência anual de lesões nos membros inferiores em indivíduos saudáveis é de $2 \%$, ao passo que entre diabéticos o índice varia de $5 \%$ a $7 \%$ 
(LEONE et al., 2012). Um modelo hipotético brasileiro, elaborado por pesquisadores brasileiros para uma população de 7,1 milhões de pessoas com diabetes mellitus, projeta 484.500 úlceras que seriam responsáveis por 169.600 internações, 80.900 amputações e 21.700 mortes (OLIVEIRA; VENCIO, 2015). Um cenário verdadeiramente alarmante.

Lesões crônicas geram desconforto e má qualidade de vida para o paciente diabético, submetido à dor crônica, restrições laborais e, também, ao prejuízo psicológico, incluindo-se aqui o isolamento social, decorrente das diversas condições acima citadas. Em média, cerca de $50 \%$ dos pacientes internados por um período que pode chegar a 90 dias, em enfermarias dos Serviços de Endocrinologia nos Hospitais Universitários, são pacientes diabéticos com lesões graves nos membros inferiores (PEDROSA, 1997), o que denota considerável ônus econômico e social.

A resolução de feridas em pacientes diabéticos, todavia, é prejudicada por diversos fatores associados ao diabetes. A hiperglicemia interfere prejudicialmente na estrutura de proteínas importantes, como o colágeno, o que diminui a solubilidade da matriz extracelular e mantém o quadro inflamatório. O ambiente da lesão torna-se continuamente inflamatório, sendo persistente a presença de neutrófilos, macrófagos, citocinas pró-inflamatórias como Interleucina-1 (IL-1), Interleucina-6 (IL-6) e o fator de necrose tumoral- $\alpha$ (Tumor Necrosis Factor- $\alpha$-TNF- $\alpha$ ), além de metaloproteinases (PRADHAN et al., 2009).

Ainda, em diabéticos, é observada a disfunção na micro e macrovasculatura, que está estreitamente associada a um ambiente de hipóxia no leito das lesões e ao aumento de radicais livres, prejudicando o metabolismo celular e a cicatrização. A angiogênese também é prejudicada, uma vez que células progenitoras endoteliais são mais escassas em pacientes diabéticos, o que colabora para a deficiência na perfusão das lesões cutâneas. A sinalização por neuropeptídios também é danificada, mediante baixa expressão de moléculas como a substância $\mathrm{P}$, neuropeptídeo $\mathrm{Y}$ e o peptídeo relacionado ao gene da calcitonina, capazes de influenciar células endoteliais, fibroblastos e queratinócitos (BALTZIS; ELEFTHERIADOU; VEVES, 2014). 
Coletivamente, diversos defeitos fisiológicos e bioquímicos, em pacientes diabéticos, impedem, ou praticamente impossibilitam, o processo normal de cicatrização, uma vez que são relacionados ao prejuízo e anormalidade na resposta angiogênica, síntese proteica, fisiologia de células inflamatórias, formação de tecido de granulação, proliferação e migração de fibroblastos e queratinócitos (prematuramente senescentes), bem como na produção de fatores de crescimento (YANG et al., 2013). Diante deste cenário, estratégias tópicas com caráter anti-inflamatório, associadas a fatores de crescimento, sinalizam considerável potencial terapêutico.

As abordagens terapêuticas para úlceras diabéticas são diversas, mas compartilham em comum o desafio de estimular a cicatrização. As estratégias clássicas, empregadas como técnicas de rotina são: 1) Desbridamento, que remove regiões de calosidade epidérmica, tecidos necróticos, partículas estranhas e elementos microbiológicos; 2) Curativos como gaze, filmes, espumas, alginatos, hidrocoloides e hidrogeis com potencial para prevenir infecções secundárias, proporcionar um ambiente umidificado e remover exsudatos; 3) Remoção da pressão sobre a lesão com dispositivos que auxiliam na redistribuição da pressão exercida sobre o membro afetado; 4) Revascularização, como exemplos, técnicas de enxertos, angioplastia, by-pass e endarterectomia; 5)Controle de infecções com terapias antimicrobianas e 6) Controle da dieta, glicemia e dislipidemia. Essas medidas, contudo, são paliativas e frequentemente ocorrem recidivas das úlceras (AGALE, 2013; AMATO et al., 2015; GAME et al., 2016; O'LOUGHLIN; O'BRIEN, 2011).

Além dos tratamentos convencionais, opções terapêuticas auxiliares mais sofisticadas têm sido utilizadas: 1) Substitutos de pele produzidos por técnicas da bioengenharia tecidual; 2) Fatores de crescimento; 3) Oxigenoterapia hiperbárica; 4) Terapia por pressão negativa; 5) Terapias por ondas de choque; 6) Impressão tridimensional de equivalentes cutâneos; dentre outros (BALTZIS; ELEFTHERIADOU; VEVES, 2014; GOULD et al., 2015).

Dois substitutos de pele, Apligraft $\AA$ e Dermagraft ${ }^{\circledR}$ (Organogenesis, Inc., Canton, Massachusetts, EUA), bem como o fator de crescimento derivado de plaquetas (Platelet derived growth factor - PDGF) em forma de gel ou 
becaplermina - Regranex® (Smith \& Nephew, Londres, Reino Unido), são aprovados pelo órgão de regulamentação americano Food and Drug Administration (FDA). O Apligraft ${ }^{\circledR}$ é composto por uma matriz extracelular (colágeno tipo I bovino), fibroblastos e queratinócitos alogênicos e um estrato córneo, já o Dermagraft $\circledast$ é um produto alogênico com fibroblastos imersos em uma rede de poliglactina bioabsorvível, contendo também fatores de crescimento como PDGF, fator de crescimento semelhante à insulina (Insulin growth factor - IGF), fator de crescimento de queratinócitos (Keratinocyte growth factor - KGF), fator de crescimento semelhante ao fator de crescimento epidermal (epidermal growth factor - EGF) ligado à heparina (Heparin-binding EGF-like growth factor - HBEGF), fator de crescimento endotelial vascular (Vascular endotelial growth factor - VEGF), fator de crescimento transformante beta-1 (transforming growth factor beta-1 - TGF- $\beta 1$ ), fator de crescimento transformante beta-3 (transforming growth factor beta-3 - TGF- $\beta 3$ ) e TGF- $\alpha$ (AMATO et al., 2015; BALTZIS; ELEFTHERIADOU; VEVES, 2014).

Embora os resultados sejam positivos, algumas limitações são associadas aos substitutos de pele, como o risco de rejeição, baixa integração e vascularização, alto custo, baixa durabilidade e a inabilidade da regeneração dos anexos epidérmicos. A aplicação de fatores de crescimento isolados também apresenta desvantagens como o alto custo, degradação no leito das lesões devido à inflamação crônica e a inabilidade de um único fator estimular a cicatrização, o que resulta em baixos índices de cicatrização, não superiores a 40\%, para úlceras cutâneas crônicas de pacientes diabéticos (BALTZIS; ELEFTHERIADOU; VEVES, 2014; GAME et al., 2016).

As terapias atualmente empregadas para o tratamento de lesões ulcerosas em pés diabéticos envolvem uma abordagem multidisciplinar em virtude da complexidade e abrangência do quadro clínico associado. Novas pesquisas buscam superar as limitações das terapias convencionais e associadas, com estratégias de baixo custo, mas, principalmente, reconhecida eficácia direcionada para a correção dos fatores que promovem a cronicidade das lesões em pacientes diabéticos. Neste cenário, experimentos de terapia gênica com vetores virais, contendo genes de fatores de crescimento, a administração de análogos da angiotensina, neuropeptídios, inibidores de 
citocinas, bem como a terapia com células-tronco adultas têm demonstrado resultados promissores. É necessário, no entanto, estudos clínicos mais abrangentes para o reconhecimento da eficácia clínica e disponibilização para os pacientes diabéticos (AMATO et al., 2015; BALTZIS; ELEFTHERIADOU; VEVES, 2014; GAME et al., 2016; GOULD et al., 2015).

\subsection{Cicatrização}

O processo de cicatrização de úlceras compreende um mecanismo complexo, porém dinâmico e que envolve diversos tipos celulares, mediadores solúveis, bem como a matriz extracelular. Classicamente, a cicatrização normal é dividida em três fases contínuas com sobreposição: hemostasia/inflamação, formação tecidual (proliferativa) e remodelamento (SINGER; CLARK, 1999). Em úlceras cutâneas crônicas, a fase inflamatória é contínua e, por este motivo, a lesão permanece estagnada em uma ou mais fases do processo de cicatrização.

A Figura 2 ilustra de maneira esquemática as etapas do processo de cicatrização normal, bem como o que acontece em úlceras cutâneas crônicas, onde a cicatrização é prejudicada.

Figura 2 - Esquemas representativos do processo de cicatrização.

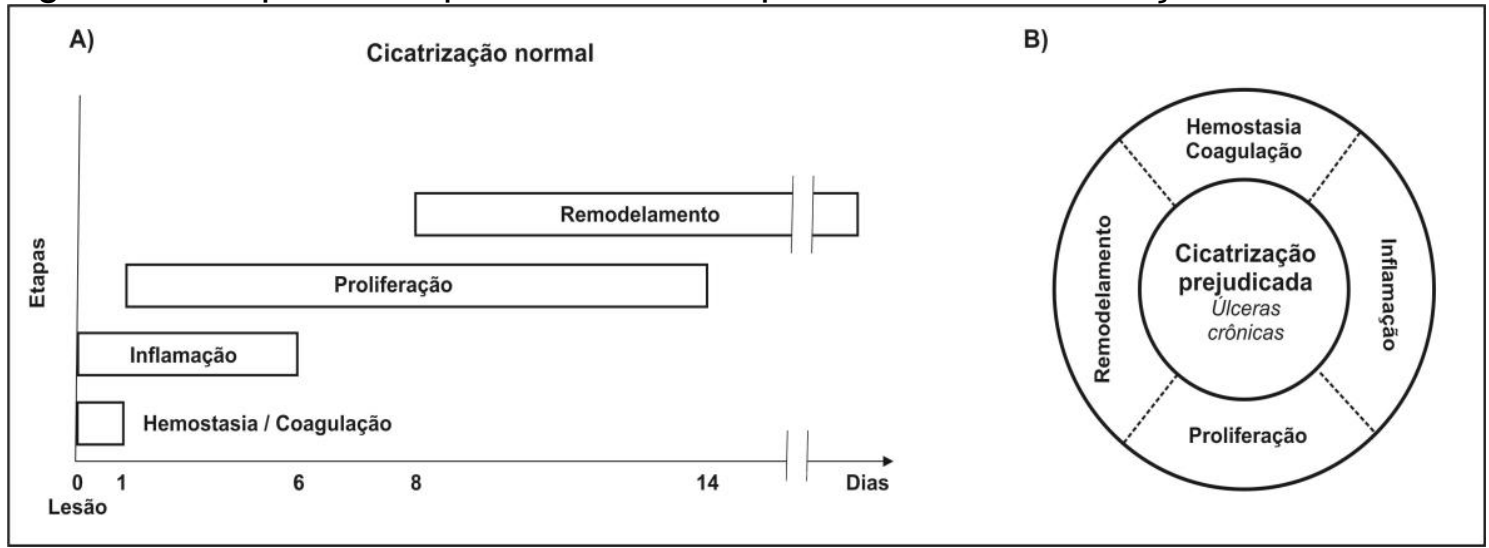

A) Curso normal da cicatrização com etapas contínuas e sobrepostas. B) Cicatrização prejudicada, estagnada e característica de úlceras cutâneas crônicas. As etapas não são lineares e nem sequenciais. Diferentes partes das lesões crônicas podem estar em diferentes fases do processo de cicatrização. Fonte: Adaptado de Falanga, 2012. 
A fase inflamatória tem início com o rompimento de vasos, em decorrência da lesão, e formação de um coágulo sanguíneo que restitui a hemostasia e atua como uma matriz extracelular provisória para permitir a migração celular. Além de colaborar para a formação do coágulo, as plaquetas sofrem degranulação e liberam diversos fatores de crescimento mediadores da cicatrização, tais como PDGF, que atrai e ativa macrófagos e fibroblastos. Mediadores vasoativos e fatores quimiotáticos são continuamente liberados durante a coagulação por células do parênquima, que atraem leucócitos inflamatórios para a lesão (CLARK, 1996). A Tabela 1 sumariza as citocinas envolvidas no processo de cicatrização, bem como as principais funções.

Uma vez infiltrados na lesão, os neutrófilos promovem a limpeza da área lesada removendo partículas estranhas e bactérias, que podem também ser fagocitadas por macrófagos. Ao mesmo tempo, em resposta a mediadores quimiotáticos, os monócitos são transformados em macrófagos ativados que liberam PDGF e VEGF, fatores que dão início à formação do tecido de granulação (BARRIENTOS et al., 2008; LEIBOVICH; ROSS, 1975). 
Tabela 1 - Citocinas, células secretoras e principais funções durante a cicatrização.

\begin{tabular}{|c|c|c|}
\hline Citocina & Fonte & Função \\
\hline EGF & Plaquetas, fibroblastos, CTM & $\begin{array}{l}\text { Migração e proliferação } \\
\text { celular }\end{array}$ \\
\hline ECGF & Plaquetas & $\begin{array}{l}\text { Proliferação de células } \\
\text { endoteliais e } \\
\text { angiogênese }\end{array}$ \\
\hline TGF- $\alpha$ & $\begin{array}{l}\text { Macrófagos, células epidermais, } \\
\text { fibroblastos }\end{array}$ & $\begin{array}{l}\text { Migração e proliferação } \\
\text { celular }\end{array}$ \\
\hline HBEGF & Macrófagos, CTM & $\begin{array}{l}\text { Migração e proliferação } \\
\text { celular }\end{array}$ \\
\hline FGF & $\begin{array}{c}\text { Macrófagos, células epidermais e } \\
\text { endoteliais, fibroblastos, } \\
\text { plaquetas, CTM }\end{array}$ & $\begin{array}{l}\text { Angiogênese e } \\
\text { proliferação de } \\
\text { fibroblastos }\end{array}$ \\
\hline KGF & CTM & $\begin{array}{l}\text { Migração e proliferação } \\
\text { de queratinócitos }\end{array}$ \\
\hline TGF- $\beta 1$ e $\beta 2$ & $\begin{array}{l}\text { Macrófagos, plaquetas, células } \\
\text { epidermais, fibroblastos, CTM }\end{array}$ & $\begin{array}{l}\text { Migração de } \\
\text { queratinócitos, } \\
\text { quimiotaxia de } \\
\text { fibroblastos e } \\
\text { macrófagos, síntese de } \\
\text { matriz extracelular e } \\
\text { remodelamento }\end{array}$ \\
\hline $\begin{array}{l}\text { TGF- } \beta 3 \\
\text { PDGF }\end{array}$ & $\begin{array}{c}\text { Macrófagos, CTM } \\
\text { Macrófagos, células epidermais e } \\
\text { endoteliais, fibroblastos, } \\
\text { plaquetas, CTM }\end{array}$ & $\begin{array}{l}\text { Prevenção de cicatrizes } \\
\text { Proliferação e } \\
\text { quimioatração de } \\
\text { fibroblastos, } \\
\text { quimioatração e } \\
\text { ativação de macrófagos }\end{array}$ \\
\hline VEGF & $\begin{array}{c}\text { Macrófagos, células epidermais e } \\
\text { endoteliais, fibroblastos, } \\
\text { plaquetas, neutrófilos, CTM }\end{array}$ & $\begin{array}{c}\text { Angiogênese, } \\
\text { permeabilidade } \\
\text { vascular, proliferação e } \\
\text { migração celular, tecido } \\
\text { de granulação }\end{array}$ \\
\hline TNF- $\alpha$ & Macrófagos, neutrófilos & $\begin{array}{l}\text { Inflamação e } \\
\text { reepitelização }\end{array}$ \\
\hline IL-1 & $\begin{array}{c}\text { Macrófagos, neutrófilos, } \\
\text { monócitos, células epidermais, } \\
\text { CTM }\end{array}$ & $\begin{array}{l}\text { Inflamação e } \\
\text { reepitelização }\end{array}$ \\
\hline IGF-1 & $\begin{array}{l}\text { Fibroblastos, células epidermais, } \\
\text { Plaquetas }\end{array}$ & $\begin{array}{l}\text { Reepitelização e } \\
\text { formação de tecido de } \\
\text { granulação }\end{array}$ \\
\hline CSF-1 & CTM & $\begin{array}{c}\text { Ativação de macrófagos } \\
\text { e formação de tecido de } \\
\text { granulação }\end{array}$ \\
\hline
\end{tabular}


HBEGF: Fator de crescimento semelhante ao EGF ligado à heparina (Heparin-binding EGF-like growth factor).

FGF: Fator de crescimento de fibroblastos (Fibroblast growth factor).

KGF: Fator de crescimento de queratinócitos (Keratinocyte growth factor).

TGF- $\beta 1$ : Fator de crescimento transformante beta-1 (Transforming growth factor- $\beta 1$ ).

TGF- $\beta 2$ : Fator de crescimento transformante beta-2 (Transforming growth factor- $\beta 2$ ).

TGF- $\beta 3$ : Fator de crescimento transformante beta-3 (Transforming growth factor- $\beta 3$ ).

PDGF: Fator de crescimento derivado de plaquetas (Platelet derived growth factor).

VEGF: Fator de crescimento endotelial vascular (Vascular Endotelial Growth Factor).

TNF-a: Fator de necrose tumoral alfa (Tumor Necrosis Factor- $\alpha$ ).

IL-1: Interleucina 1.

IGF: Fator de crescimento semelhante à insulina (Insulin Growth Factor).

CSF: Fator de estimulação de colônias (Colony Stimulating Factor).

CTM: Células-tronco mesenquimais.

Fonte: modificado de Singer e Clark, 1999.

Poucas horas após a ocorrência da lesão, há o início da reepitelização, onde, a priori, células epidermais de anexos, como exemplo, as foliculares, promovem a limpeza do coágulo sanguíneo e estroma lesado. Alterações fenotípicas, como retração dos tonofilamentos, dissolução dos desmossomos e hemidesmossomos, bem como a formação de actina periférica colaboram para o processo de migração lateral das células epidermais. As células migratórias dissecam a ferida, separando a lesão do tecido saudável, sendo este processo dependente de colagenase liberada pelas células epidermais para degradar a matriz extracelular (PILCHER et al., 1997). Assim, 1 a 2 dias após a lesão, há intensa proliferação dos queratinócitos localizados nas margens da úlcera, promovida por EGF, TGF e KGF (CLARK, 1996).

Em um processo normal de cicatrização, cerca de 4 dias após a lesão, um novo estroma, ou tecido de granulação, invade a área ulcerosa. Há a formação de novos vasos sanguíneos com aparência granular no estroma, com o propósito de conduzir oxigênio e nutrientes. Ainda, há a proliferação e migração de fibroblastos para o sítio da ferida, que produzem a matriz extracelular de suporte para o crescimento, modulada por PDGF, TGF- $\beta 1$ e componentes da matriz extracelular,. Macrófagos no sítio da ferida atuam como fontes de fatores de crescimento que estimulam a angiogênese e fibroplasia (síntese de colágeno). Com o passar do tempo, a matriz provisória sintetizada pelos fibroblastos torna-se colagenosa e o tecido de granulação rico em fibroblastos transforma-se em uma cicatriz. (SINGER; CLARK, 1999). 
A contração da ferida, regulada pela ação coordenada de citocinas, células e matriz extracelular tem início com a aquisição do fenótipo de miofibroblastos, com largos feixes de actina, pelos fibroblastos, cerca de 10 dias após a lesão. O remodelamento do colágeno, equivalente à substituição de colágeno fibrilar, rapidamente acumulado por largos feixes de colágeno, durante a transição do tecido de granulação para o tecido cicatricial, depende da síntese e catabolismo do colágeno, sendo a degradação do colágeno comandada por uma sequência de metaloproteinases e respectivos inibidores (MEHENDALE; MARTIN, 2001).

Neste sentido, o amplo conhecimento dos eventos celulares e cascatas moleculares, orquestrados por uma sequência coordenada de fatores de crescimento, células e componentes da matriz extracelular, fundamentam a proposição de novas opções terapêuticas utilizando fatores de crescimento, isoladamente, como PDGF, ou um painel de diferentes fatores com o propósito de acelerar a cicatrização. Contudo, o emprego de fatores isolados não tem mostrado resultados satisfatórios para o processo de reparo. Deste modo, torna-se extremamente interessante a administração de um conjunto ou combinação de vários fatores de crescimento (PIERCE; MUSTOC, 1995), com potencial terapêutico buscando otimizar o reparo cutâneo, particularmente nas úlceras crônicas de difícil cicatrização.

\subsection{Plasma rico em plaquetas (PRP)}

As plaquetas são fragmentos celulares, anucleados, formadas a partir do fracionamento de megacariócitos provenientes da medula óssea. Megacariócitos são megacarioblastos maduros com diâmetro de $100 \mu \mathrm{m}$ e que, uma vez amadurecido e fragmentado o citoplasma, podem originar até 1.000 plaquetas com diâmetro de 2-4 $\mu \mathrm{m}$, sendo cada plaqueta equivalente a um fragmento do citoplasma megacariocítico. As plaquetas têm vida média de 10 dias, período em que colaboram para etapas críticas dos processos de coagulação, hemostasia, inflamação e ativação do sistema imunológico. Quando envelhecidas, ou não funcionais, as plaquetas são removidas da 
circulação sanguínea pelo baço (CARR, 1997; NURDEN, 2011; TRZECIAKRYCZEK; TORKARZ-DEPTULA; DEPTULA, 2013).

O citoplasma plaquetário é rico em grânulos ( $\alpha$, densos e T), lisossomos, mitocôndrias e mRNA. Nos a-grânulos, organelas plaquetárias mais abundantes (50-80 por plaqueta), são estocadas, além dos fatores de crescimento listados na Tabela 1 (EGF, ECGF, FGF, TGF, PDGF, VEGF, IGF), diversas proteínas, enzimas e fatores de coagulação que, em conjunto com as citocinas, participam da cascata de coagulação/cicatrização (FOSTER et al., 2009). Na Tabela 2 são encontradas as moléculas bioativas (proteínas, enzimas e fatores de coagulação) presentes nos $\alpha$-grânulos das plaquetas.

Tabela 2 - Proteínas, enzimas e fatores de coagulação encontrados nos $\alpha$ grânulos plaquetários e respectivas funções.

\begin{tabular}{|c|c|c|}
\hline $\begin{array}{c}\text { Categorias } \\
\text { de atividades }\end{array}$ & Biomoléculas & Função \\
\hline $\begin{array}{l}\text { Proteínas } \\
\text { adesivas }\end{array}$ & $\begin{array}{l}\text { Fibrinogênio } \\
\text { Fibronectina }\end{array}$ & $\begin{array}{l}\text { Formação do coágulo de fibrina. } \\
\text { Adesão, crescimento, migração e } \\
\text { diferenciação celular via ligação com } \\
\text { integrinas. }\end{array}$ \\
\hline & Vitronectina & Adesão celular e quimiotaxia. \\
\hline & Trombospondina-1 & Inibição da angiogênese. \\
\hline $\begin{array}{l}\text { Fatores de } \\
\text { coagulação }\end{array}$ & $\begin{array}{l}\text { Fator } \mathrm{V}, \text { fator } \mathrm{XI}, \\
\text { proteína } \mathrm{S}, \text { anti- } \\
\text { trombina }\end{array}$ & $\begin{array}{l}\text { Ativação da trombina, formação do } \\
\text { coágulo de fibrina. }\end{array}$ \\
\hline $\begin{array}{l}\text { Fatores } \\
\text { fibrinolíticos }\end{array}$ & $\begin{array}{l}\text { Plasminogênio } \\
\text { Inibidor do ativador } \\
\text { do plasminogênio }\end{array}$ & $\begin{array}{l}\text { Produção de plasmina. } \\
\text { Produção de plasmina (regulação). }\end{array}$ \\
\hline & $\alpha-2$ antiplasmina & Inativação de plasmina. \\
\hline $\begin{array}{l}\text { Proteases e } \\
\text { antiproteases }\end{array}$ & $\begin{array}{l}\text { TIMP-4 } \\
\text { Metaloprotease- } 4 \\
\text { a1-antitripsina }\end{array}$ & $\begin{array}{l}\text { Degradação da matriz (regulação). } \\
\text { Degradação da matriz. } \\
\text { Inibição de enzimas. }\end{array}$ \\
\hline $\begin{array}{l}\text { Proteínas } \\
\text { básicas }\end{array}$ & $\begin{array}{l}\text { Fator-4-plaquetário } \\
\beta \text {-tromboglobulina }\end{array}$ & $\begin{array}{l}\text { Inibição da angiogênese. } \\
\text { Inibição da angiogênese e ativação } \\
\text { plaquetária. }\end{array}$ \\
\hline & Endostatinas & $\begin{array}{l}\text { Inibição da angiogênese e da migração } \\
\text { de células endoteliais. }\end{array}$ \\
\hline $\begin{array}{l}\text { Glicoproteínas } \\
\text { de membrana }\end{array}$ & Ligante de CD40 & $\begin{array}{l}\text { Inflamação, síntese de interleucinas e } \\
\text { integrinas, adesão plaquetária e } \\
\text { sinalizacão celular. }\end{array}$ \\
\hline & P-selectina & $\begin{array}{l}\text { Adesão celular, ligação e recrutamento } \\
\text { de leucócitos. }\end{array}$ \\
\hline
\end{tabular}

TIMP-4: Inibidor tecidual de metaloproteinase-4 (Tissue inhibitor of metalloproteinase-4). 
Fonte: modificado de Foster et al. 2009.

Nos grânulos densos (5-8 por plaqueta), há também moléculas bioativas com participação de fundamental importância durante 0 processo de cicatrização. Os grânulos $T$ foram identificados recentemente e podem estar relacionados e contribuir para o processo de secreção (HEIJNEN; VAN DER SLUIJS, 2015). Na Tabela 3 estão listadas as biomoléculas estocadas nos grânulos densos.

Tabela 3 - Biomoléculas encontradas nos grânulos densos das plaquetas e respectivas funções.

\begin{tabular}{|c|c|}
\hline cula & Função \\
\hline Histamina & Permeabilidade capilar, ativação e atração macrofágica \\
\hline & Regulação da circulação, neurotransmiss \\
\hline & $\begin{array}{l}\text { Permeabilidade capilar, vasoconstrição, } \\
\text { macrofágica. }\end{array}$ \\
\hline DP & o plaquetária. \\
\hline TP & ária ao colé \\
\hline $\mathrm{Ca}^{2+}$ & $\begin{array}{l}\text { Cofator para agregação plaquetária e formação da rede de } \\
\text { fibrina. }\end{array}$ \\
\hline atecc & Resposta ao stress. \\
\hline
\end{tabular}

Fonte: modificado de Foster et al. 2009.

A análise proteômica de plaquetas humanas revela mais de 4.000 proteínas, sendo apenas poucas centenas significativamente liberadas após estimulação (BURKHART et al., 2012; MCFADYEN; KAPLAN, 2015). O conteúdo granular das plaquetas é, portanto, uma rica fonte de citocinas, quimiocinas, fatores de crescimento e coagulação, proteínas adesivas, imunoglobulinas, proteoglicanos, proteases e inibidores que desempenham as respectivas funções biológicas de forma autócrina e parácrina, bem como conferem às plaquetas, papéis cruciais durante o reparo tecidual.

A manutenção e controle da hemostasia são, majoritariamente, decorrentes da ação plaquetária. Em condições normais ou fisiológicas, as plaquetas circulam pela corrente sanguínea sem interagir com o endotélio vascular, devido a mecanismos de repulsão entre as plaquetas e as células endoteliais. No entanto, quando a camada endotelial é rompida, em consequência de, por exemplo, uma lesão, há a exposição da matriz 
subendotelial e de moléculas que vão desencadear a precipitação das plaquetas para controle hemorrágico. Receptores de membranas plaquetários interagem, principalmente com o fator de von Willebrand e colágeno, mas também outros substratos como laminina, trombospondina, fibronectina $\mathrm{e}$ vitronectina podem se ligar às plaquetas e permitir a adesão ao subendotélio vascular (RUMBAUT; THIAGARAJAN, 2010).

Após a adesão, as plaquetas são ativadas pela ligação de agonistas, como ADP, trombina e colágeno, a receptores específicos com o propósito final de aumentar a concentração de cálcio intracitoplasmático. O aumento de cálcio desencadeia consideráveis mudanças funcionais e estruturais nas plaquetas. Uma vez ativadas, as plaquetas, outrora discoides, se transformam em esferas com longos pseudópodes e o conteúdo dos grânulos é lançado no lúmen do sistema canicular aberto para alcançar o exterior, processo também conhecido como degranulação (HEIJNEN; VAN DER SLUIJS, 2015).

A liberação de agonistas amplifica a ativação de outras plaquetas recrutadas e agregadas, também com o auxílio das projeções de membrana, que aumentam o contato plaqueta-plaqueta. Após a agregação e a ativação, as plaquetas tornam-se superfícies catalíticas para a ativação da hemostasia secundária, ou seja, a cascata de coagulação. Diversas enzimas e cofatores atuam de forma coordenada para a ativação de fatores de coagulação até a conversão da protrombina, proteína plasmática, em trombina, via fator Xa, na presença do fator Va e cálcio. A trombina, por sua vez, converte o fibrinogênio, glicoproteína do plasma, em fibrina e, deste modo, uma rede é formada, o que estrutura o coágulo ou tampão hemostático permanente (HEIJNEN; VAN DER SLUIJS, 2015; NURDEN, 2011; RUMBAUT; THIAGARAJAN, 2010).

Além da ação imediata após trauma ou inflamação, as plaquetas atuam ainda nos estágios subsequentes com o propósito da completa cicatrização (CARR, 1997). Ademais, as plaquetas são responsáveis pelo recrutamento de leucócitos e células progenitoras até a lesão e ambiente inflamatório. Etapas críticas para o reparo tecidual, como promoção da quimiotaxia, angiogênese, proliferação celular, bem como a alteração na permeabilidade celular, são também provenientes da ação plaquetária (KAZAKOS et al., 2009; NURDEN, 2011). 
A concentração enriquecida de todos os fatores plaquetários pode ser obtida mediante centrifugação de sangue anticoagulado. A fração sanguínea composta por concentração plaquetária significante, maior que os níveis basais, em um pequeno volume de plasma, é conhecida como plasma rico em plaquetas (PRP) (MARX, 2004). Não há, na literatura, contudo, uma padronização relativa à concentração plaquetária no PRP, sendo poucos os estudos que avaliam a diferença de concentrações para uma mesma aplicação e grande parte dos trabalhos sequer relatam a quantificação dos elementos sanguíneos (DELONG; RUSSELL; MAZZOCCA, 2012). Tal escassez de dados e disparidade quali-quantitativa conduzem à controvérsia de resultados (MARQUES et al., 2015; SCHEPULL et al., 2011) e à necessidade premente de alicerçar os estudos futuros em rigorosa metodologia científica para produção e aplicação do PRP nas mais diversas áreas.

A concentração de plaquetas no sangue pode variar entre indivíduos e também no decorrer dos dias, sendo a concentração média de 150.000 a 350.000 plaquetas $/ \mu \mathrm{L}$ de sangue. Em acordo com o método de produção, é possível obter PRPs com concentrações plaquetárias de 1 a 6 vezes maiores que os valores basais (DELONG; RUSSELL; MAZZOCCA, 2012).

A produção do PRP é baseada no princípio de separação celular por centrifugação diferencial (SCARANTO, 2002). Deste modo, o PRP pode ser obtido por dispositivos comerciais condensados em kits, ou mesmo por meio de centrifugação convencional (CASTILLO et al., 2010). Os protocolos variam em relação à força centrífuga, tempo e número de centrifugações para separação do plasma e concentração das plaquetas em um pequeno volume (AMABLE et al., 2013; JO et al., 2013). Ainda, além das plaquetas, há também a variação na quantidade de hemácias e leucócitos, presentes mesmo em quantidades mínimas (DELONG; RUSSELL; MAZZOCCA, 2012). Peculiaridades e diferenças metodológicas tornam o produto final único, o que também dificulta comparações em modelos autólogos.

Após a concentração plaquetária e formação do PRP, em acordo também com o tipo de aplicação pretendida, são utilizados ativadores que promovem a agregação e degranulação das plaquetas, com consequente polimerização da fibrina. Os ativadores mais comumente utilizados são a 
trombina (bovina ou autóloga), colágeno tipo I, cloreto e gluconato de cálcio a 10\% (CASTILLO et al., 2010; DELONG; RUSSELL; MAZZOCCA, 2012; MARQUES et al., 2015; SCARANTO, 2002). Em função do tipo e concentração do ativador, o PRP pode adquirir a forma de gel, coágulo ou líquido, sendo este último quando são empregadas pequenas concentrações de sais de cálcio, ou quando o PRP é aplicado sem ser ativado, para que as plaquetas sejam degranuladas mais lentamente e de forma endógena (DELONG; RUSSELL; MAZZOCCA, 2012).

Apesar da extensa variação metodológica, diante do benefício funcional associado às plaquetas, o PRP tem sido utilizado com sucesso em diversas áreas cirúrgicas com o propósito do reparo tecidual, em especial na regeneração óssea e no controle de feridas crônicas de difícil cicatrização (ANITUA et al., 2008; ANITUA; TROYA; ORIVE, 2013; KAZAKOS et al., 2009; MARQUES et al., 2015; MARX, 2004; YANG et al., 2011).

O mecanismo de ação do PRP está relacionado ao papel fisiológico das plaquetas, ou seja, à degranulação dos grânulos $\alpha$, compostos por fatores de crescimento sintetizados e estocados (MARX, 2004). Logo após a ativação e liberação do conteúdo granular, os fatores de crescimento ligam-se aos receptores transmembrana presentes em células-tronco mesenquimais (CTM), fibroblastos, osteoblastos, células endoteliais e epidermais presentes no sítio da lesão. As moléculas provenientes das plaquetas induzem então a proliferação, migração e atuação de outros tipos celulares, como por exemplo, células do sistema imunológico, durante o reparo tecidual (MARX et al., 1998).

Em modelos animais de lesões cutâneas, Vermeulen e colaboradores relataram, em 2009, a atuação do PRP como uma biomatriz que organiza a matriz extracelular, promove a angiogênese e estimula a reepitelização em modelo porcino. Ainda, o exame histológico de lesões em orelhas de coelhos New Zealand, após injeção intralesional de PRP, evidencia a redução da inflamação, grande quantidade de fibroblastos em disposição organizada e melhor orientação do colágeno, em comparação ao grupo não tratado com PRP (DIONYSSIOU et al., 2012).

Em equinos, a aplicação do gel de PRP sobre úlceras cutâneas nos membros inferiores acelera a diferenciação de queratinócitos e, portanto, a 
reconstituição epidérmica, bem como promove a formação de uma matriz de colágeno densa e organizada, em comparação com lesões controle (CARTER et al., 2003). Os resultados da pesquisa básica, em modelos animais, sinalizam um estímulo positivo do PRP sobre a regeneração dérmica e epidérmica e, desta forma, evidenciam e refletem os efeitos do PRP na cicatrização de úlceras cutâneas em pacientes humanos.

Em 1986, Knighton e colaboradores da Universidade de Minnesota relataram os resultados da aplicação tópica diária de uma pomada elaborada com o produto da degranulação plaquetária (autóloga) com trombina sobre o leito de úlceras crônicas de diversas etiologias. Foram tratados 41 pacientes com 71 úlceras cutâneas e a média relativa ao tempo para $100 \%$ de cicatrização foi de 10,6 $\pm 6,1$ semanas. O trabalho pioneiro verificou o estímulo da formação de tecido de granulação e reepitelização das úlceras após o tratamento com fatores de crescimento derivados de plaquetas, bem como a segurança, eficácia e excelente custo-benefício do método. Estes resultados, embora deficientes quanto ao controle, randomização e prospecção, sinalizaram a relevância das plaquetas no contexto da cicatrização de lesões cutâneas crônicas e, deste modo, abriram caminho para o avanço da investigação clínica.

O primeiro estudo clínico prospectivo, randomizado, duplo-cego, com o propósito de avaliar a eficácia referente ao emprego do PRP (processado para formação do lisado, ou seja, produto resultante da degranulação plaquetária) em úlceras cutâneas crônicas (sem cicatrização significante por, no mínimo, 8 semanas) de pacientes diabéticos, foi conduzido e relatado por Steed e colaboradores, em 1992. O grupo americano verificou a eficácia da aplicação tópica diária de gel rico em produtos da degranulação plaquetária (CT-102), desta vez, um produto homólogo, em comparação com o controle tratado com solução salina. Os índices de cicatrização médios obtidos para os grupos tratados e controle foram, respectivamente, $94 \%$ e $73 \%(p<0,02)$, o que indica o estímulo da cicatrização em úlceras cutâneas crônicas de membros inferiores em pacientes diabéticos tratados com lisado plaquetário.

Um estudo de coorte, realizado a partir de dados provenientes de 26.599 pacientes com úlceras de pé diabético e acompanhados entre 1988 e 1997, 
mostrou um índice de cicatrização médio de $50 \%$ no grupo tratado com lisado de plaquetas e $41 \%$ no grupo controle $(p<0,05)$. Deste modo, os autores concluíram que o tratamento com lisado de plaquetas é mais eficiente que o tratamento convencional para úlceras neuropáticas de pacientes diabéticos (MARGOLIS et al., 2001).

Em pacientes diabéticos, ainda, Driver e colaboradores (2006) conduziram um estudo prospectivo controlado, multicêntrico, randomizado com o propósito de avaliar a segurança e eficácia da aplicação do PRP autólogo na forma gel em úlceras crônicas. Os autores concluíram que o uso de PRP autólogo é seguro, mesmo com a utilização de trombina bovina, e tem grande potencial para promover a cicatrização na maioria das úlceras crônicas de pés diabéticos.

Mais recentemente, Shan e colaboradores (2013), relataram a capacidade do PRP homólogo em estimular a proliferação e migração celular, bem como acelerar a cicatrização de úlceras diabéticas, possivelmente pelo estímulo da vascularização e epitelização. Em pacientes diabéticos com doença arterial periférica, a aplicação do gel de PRP em úlceras cutâneas crônicas promoveu um índice de cicatrização superior a 90\% em 72,2\% dos pacientes, sem efeitos adversos, em até 16 semanas após o início de um tratamento realizado duas vezes por semana (KONTOPODIS et al., 2016).

Coletivamente, $87,5 \%$ dos estudos controlados e relatados na literatura resultaram em um efeito positivo e benéfico relativo ao tratamento com PRP em úlceras cutâneas crônicas de pacientes diabéticos (PICARD et al., 2015). Desta forma, o emprego do PRP tem sido considerado para o tratamento de úlceras crônicas não responsivas aos tratamentos convencionais (GURGEN, 2008).

Há, na literatura, poucos trabalham que relatam a eficiência do emprego de PRP em lesões de pele, uma vez que são 3 décadas de investigação básica e experimental. Todavia, os resultados estimulam a pesquisa clínica referente aos fatores plaquetários, ainda não completamente conhecidos, bem como a otimização metodológica. Ainda, os resultados com emprego de CTM da medula óssea associadas ao PRP em lesões cutâneas de modelos animais (LIAN et al., 2014) sustentam a hipótese acerca de um possível efeito benéfico, 
por ação aditiva ou sinergística, decorrente da associação de PRP e CTM como uma nova opção terapêutica para o tratamento de úlceras crônicas.

\subsection{Células-tronco mesenquimais}

No âmbito da bioengenharia tecidual, a necessidade de estratégias terapêuticas com potencial eficácia clínica tem envolvido o estudo de célulastronco. A definição clássica de uma célula-tronco abrange duas propriedades fundamentais: a autorrenovação para manutenção do pool celular indiferenciado e a diferenciação em pelo menos um tipo celular maduro (MELTON; COWAN, 2004; NATIONAL INSTITUTE OF HEALTH, 2001).

Em acordo com a origem, as células-tronco podem ser divididas em embrionárias e adultas. As células-tronco embrionárias (CTE) são provenientes da massa celular interna do blastocisto e são pluripotentes, ou seja, podem diferenciar em todos os tipos celulares, exceto placenta e anexos embrionários. Ao contrário, as células-tronco adultas (CTA) são tecido-especificas e possuem potencial de diferenciação mais limitado, no máximo multipotente. No entanto, as restrições éticas, legais e políticas associadas às CTE têm direcionado o interesse da prática e pesquisa médica para o emprego de CTA em diversas entidades clínicas, visando a recuperação morfológica e funcional de tecidos e órgãos lesados (AHMED et al., 2011; CERVELLI et al., 2011; DA SILVA MEIRELLES; CAPLAN; NARDI, 2008; FALANGA et al., 2007; LIAN et al., 2014; MIZUNO, 2009; RIBEIRO-PAES et al., 2011; STESSUK et al., 2013; WALTER et al., 2010).

Entre meados da década de 60 e início dos anos 70, o pesquisador russo Alexander Jakovlevich Friedenstein isolou da medula óssea e identificou, pioneiramente, o que hoje corresponde ao principal e mais estudado tipo de CTA. Inicialmente designadas como precursoras de fibroblastos e unidades formadoras de colônias, as células mesenquimais provenientes da medula óssea, mas não hematopoiéticas, foram descritas como clonogênicas com aspecto fibroblastoide, aderentes à superfície de cultura e com capacidade de diferenciação osteogênica (FRIEDENSTEIN; PIATETZKY-SHAPIRO; 
PETRAKOVA, 1966; FRIEDENSTEIN et al., 1968). Em 1991, Arnold Caplan propõe o termo célula-tronco mesenquimal (CTM) para denominar as célulastronco não-hematopoiéticas e provenientes do estroma da medula óssea (CAPLAN, 1991).

A partir da descoberta de Friedenstein, verdadeiro marco na história da terapia celular, diversos pesquisadores iniciaram esforços para o isolamento de CTM provenientes de outras fontes teciduais, fetais e adultas, como cordão umbilical, sangue de cordão, placenta, polpa dentária, pele, baço, pulmão, pâncreas, rim, fluido amniótico, cartilagem, tendão, músculo, endométrio, sangue menstrual, dentre outras (AMATO et al., 2015; DA SILVA MEIRELLES; CAPLAN; NARDI, 2008; MARQUEZ-CURTIS et al., 2015; MORONI; FORNASARI, 2013).

Independente da fonte tecidual, em acordo com a Sociedade Internacional de Terapia Celular, as CTM humanas são caracterizadas por três critérios mínimos: adesão ao plástico sob condições padrões de cultivo, expressão de antígenos específicos de superfície e diferenciação multipotencial. Assim, as CTM adquirem aspecto fibroblastoide in vitro e tem potencial para diferenciação osteogênica, adipogênica e condrogênica. Ainda, uma população de CTM deve expressar ( $\geq 95 \%$ positivo) dos marcadores CD105, CD73 e CD90, bem como não deve apresentar expressão ( $\leq 2 \%$ positivo) de CD45, CD34, CD14 ou CD11b, CD79a ou CD19 e HLA de classe II (DOMINICl et al., 2006). A mesma sociedade, após um consenso entre os membros, elegeu o termo células estromais mesenquimais multipotentes para designar as células mesodermais descobertas no século passado por Friedenstein (HORWITZ et al., 2005). Porém, até o momento, não há um acordo geral entre os pesquisadores e nos trabalhos relatados na literatura, quanto a uma nomenclatura universal. Certa confusão é desencadeada pelas várias características associadas às populações mesenquimais heterogêneas, sendo o acrônimo CTM ainda bastante utilizado por vários grupos de pesquisa.

Em 2001, Zuk e colaboradores isolaram CTM do tecido adiposo (CT-TA) humano e demonstraram o cultivo in vitro por longos períodos de tempo. $O$ tecido adiposo é composto principalmente por adipócitos maduros envoltos em um estroma composto por vasos sanguíneos, fibroblastos, leucócitos, 
macrófagos e pré-adipócitos (LIN et al., 2010). Ainda, a abundante rede vascular do tecido adiposo está estreitamente relacionada às CTM, uma vez que é pressuposta a associação e até mesmo a adesão das CTM nas paredes dos vasos sanguíneos (MARQUEZ-CURTIS et al., 2015).

A medula óssea representa, indubitavelmente, a principal e mais bem estudada fonte de CTM. Contudo, a coleta da medula óssea está associada a intenso desconforto para o paciente e riscos de complicações, como perfuração óssea e infecções. Em contraste, o tecido adiposo tem como principais vantagens o fácil acesso, necessidade de anestesia local apenas e pequeno desconforto para o paciente (MIZUNO, 2009).

Em termos celulares, ainda, CTM provenientes da medula óssea e do tecido adiposo são bastante similares quanto à morfologia, multipotencialidade, atividade da telomerase, antígenos de superfície, perfil genético e produção de mediadores solúveis. Ademais, quantitativamente, o tecido adiposo proporciona 500 vezes mais CTM do que a medula óssea, quando a mesma quantidade dos dois tecidos é comparada (HASSAN; GREISER; WANG, 2014). Desta forma, o tecido adiposo torna-se uma opção atraente para obtenção da linhagem mesenquimal em grande quantidade, com o propósito de transplante celular e aplicações em engenharia de tecidos (DA SILVA MEIRELLES, et al 2009).

As CT-TA são provenientes da fração vascular estromal (FVE), compondo cerca de 30 a $40 \%$ das células estromais, ao lado de células endoteliais, musculares e sanguíneas. Podem ser isoladas após digestão enzimática ou dissociação mecânica, bem como etapas de centrifugações e lavagens, sendo o aparecimento de uma população mesodermal e fibroblastoide, relativamente homogênea, após pouco tempo de cultivo in vitro (BUNNELL et al., 2008; HASSAN; GREISER; WANG, 2014; ZUK et al., 2001). A FVE, ou mesmo o lipoaspirado, requerem processamento mínimo, sem a necessidade de técnicas de cultivo e, desta forma, têm sido utilizados clinicamente sob a hipótese de que os componentes estromais podem agir sinergisticamente e realçar o potencial regenerativo das CT-TA (YOSHIMURA; SUGA; ETO, 2009). Há na literatura, todavia, evidências de que tanto a FVE quanto as CT-TA purificadas são eficientes quanto a capacidade regenerativa 
(HASSAN; GREISER; WANG, 2014), o que estimula pesquisas envolvendo cultivo celular com o propósito de usar a menor quantidade de tecido possível em abordagens clínicas.

Ao longo dos últimos anos, em escala global, a terapia celular com CTM tem sido o objetivo de pesquisas básicas e aplicadas para o tratamento de diversas doenças, inclusive lesões cutâneas de difícil cicatrização em decorrência do diabetes. $O$ racional para o extremo interesse, entusiasmo e emprego de CTM em úlceras crônicas está relacionado às características intrínsecas, sob estímulo fisiológico e patológico, com potencial para modular a inflamação e promover a cicatrização e total regeneração cutânea (AMATO et al., 2015; HASSAN; GREISER; WANG, 2014). Ainda, pacientes com lesões cutâneas secundárias às doenças crônicas, resistentes aos tratamentos convencionais e com risco de amputações, compõem a base e são os reais motivos para a investigação e elaboração de estratégias no contexto da terapia celular com propósito regenerativo.

O exato mecanismo de ação das CTM, em especial das CT-TA, sobre a regeneração cutânea, ainda não é completamente elucidado. A eficácia observada em estudos pré-clínicos e clínicos, tanto em lesões agudas e crônicas, pode estar relacionada a dois processos: diferenciação em células da pele e ação parácrina, o que qualifica as CTM como biofábricas, via secreção de mediadores biologicamente ativos (fatores de crescimento, citocinas, quimiocinas, RNA, miRNA) com capacidade de agir sobre a migração, proliferação e sobrevivência das células no leito da lesão (DA SILVA MEIRELLES; CAPLAN; NARDI, 2008; FALANGA et al., 2007; HASSAN; GREISER; WANG, 2014; LIAN et al., 2014).

No intuito de demonstrar a contribuição das CTM no reparo de lesões cutâneas, Sasaki e colaboradores (2008) relataram eventos de diferenciação em múltiplos tipos celulares da pele. Os autores inocularam, intravenosamente, CTM provenientes da medula óssea de camundongos machos C57BI6 com background EGFP (Enhanced Green Fluorescent Protein) em camundongos fêmeas submetidas à punção de biópsia. Após duas semanas da lesão, houve regeneração tecidual em todos os animais. A análise dos resultados por imunofluorescência e citometria de fluxo indicou a migração de CTM até o sítio 
da injúria, bem como a diferenciação em queratinócitos, células endoteliais e pericitos. Resultados semelhantes foram obtidos com CT-TA (EBRAHIMIAN et al., 2009), o que sinaliza a possibilidade e a capacidade das CTM se diferenciarem no ambiente de lesões cutâneas.

Em síntese, na derme, CTM transplantadas apresentam características morfológicas semelhantes a fibroblastos e células vasculo-endoteliais. $\mathrm{Na}$ epiderme, as CTM apresentam comportamento fenotípico de queratinócitos, aceleram o fechamento de úlceras, estimulam a proliferação celular, as cristas epidérmicas, a síntese de colágeno e a angiogênese, bem como beneficiam a qualidade do reparo e promovem a restauração funcional cutânea (HAlHONG; XIAOBING, 2012). Contudo, o mecanismo primário provavelmente envolve a ação parácrina das CTM nas quatro fases do processo de cicatrização cutânea (HASSAN; GREISER; WANG, 2014; YANG et al., 2013), uma vez que é baixa a sobrevivência das CTM nas lesões regeneradas (GNECCHI et al., 2008).

Em um ambiente inflamatório, CTM podem diminuir citocinas próinflamatórias, como TNF- $\alpha$ e interferon- $\gamma$, e aumentar os níveis de citocinas anti-inflamatórias, como Interleucina-10 (IL-10) e IL-4, e células T regulatórias (AGGARWAL; PITTENGER, 2005). Deste modo, as CTM possuem interessantes propriedades imunomodulatórias, uma vez que interagem com células efetoras da imunidade inata e adaptativa, além de que são capazes de controlar a inflamação crônica, produzindo citocinas que atuam no sítio da lesão e viabilizando a continuidade e andamento da cicatrização (AMATO et al., 2015; YOO et al., 2009).

Infecções, recorrentes e que contribuem para a cronicidade de úlceras cutâneas, podem ser bloqueadas pela ação antimicrobiana das CTM por via direta, com secreção de fatores antimicrobianos, e via indireta por meio do estímulo das células imunes (MAXSON et al., 2012). A ação parácrina das CTM é também estendida e exerce função sobre a angiogênese, bem como a proliferação, recrutamento e migração de macrófagos, células endoteliais, epiteliais, fibroblastos e queratinócitos, via secreção de fatores de crescimento, citocinas e quimiocinas, como VEGF, PDGF, EGF, bFGF, KGF, TGF- $\beta$, IL-6 e a quimiocina CC ligante 2 (CCL-2) (GNECCHI et al., 2008;), estimulando, 
consequentemente, a formação de tecido de granulação e a reepitelização (SORRELL; CAPLAN, 2010).

Finalmente, na etapa de remodelamento, além de regular a deposição de colágeno, as CTM têm potencial para prevenir a ocorrência de cicatrizes, interagindo com células dendríticas e fibrócitos, por meio da secreção de VEGF e do fator de crescimento de hepatócitos (HGF, hepatocyte growth factor) em um ambiente com equilíbrio de TGF- $\beta 1$ e TGF- $\beta 3$ (AMATO et al., 2015; MAXSON et al., 2012; SORRELL; CAPLAN, 2010).

Em conjunto, todas as propriedades atribuídas as CTM durante o reparo cutâneo sustentam e principiam a elucidação dos resultados positivos obtidos em processos de cicatrização de feridas. Em 2009, Nambu e colaboradores aplicaram CT-TA associadas a uma matriz de atelocolágeno e silicone em lesões cutâneas de camundongos diabéticos $(d b / d b)$. O exame histológico evidenciou, nas lesões tratadas com células, significativamente, maior índice de cicatrização, formação de tecido de granulação e capilares, bem como maior epitelização, quando comparadas ao grupo controle (sem células). Esses resultados sinalizam a eficiência de CT-TA associadas a biomateriais para estimular a cicatrização de lesões cutâneas. Ainda, em 2011, Lee e colaboradores empregaram CT-TA em gel de colágeno sobre feridas cutâneas em camundongos nude. Os autores concluíram que a linhagem mesenquimal é eficiente e estimula a cicatrização.

Em modelo porcino de lesões por excisão, CT-TA associadas a PRP proporcionam, significativamente, melhor efeito cosmético e estimulam a angiogênese via secreção de VEGF, em comparação com os grupos controles sem células ou com plasma pobre em plaquetas (PPP). Esses resultados sinalizam a possibilidade de um efeito sinérgico entre CT-TA e fatores tróficos para o estímulo da cicatrização cutânea (BLANTON et al., 2009). Resultados semelhantes, também em modelo porcino, foram obtidos por Hanson e colaboradores (2016), sendo que não foram observadas diferenças significantes quanto à eficácia de CTM da medula óssea e CT-TA para o estímulo da cicatrização cutânea.

O primeiro estudo clínico randomizado em pacientes humanos $(n=24)$ com úlceras cutâneas crônicas (secundárias ao diabetes ou à doença de 
Buerger) nos membros inferiores foi relatado por Dash e colaboradores (2009). No grupo tratado com injeções intramusculares/subcutâneas de CTM da medula óssea, houve uma redução significante na área ulcerosa, em comparação com as lesões que receberam apenas tratamento convencional (controle). Em pacientes humanos com úlceras agudas e crônicas de diversas etiologias, Falanga e colaboradores (2007) empregaram CTM da medula óssea autóloga associadas à cola de fibrina. Os resultados sinalizam a segurança e eficácia da terapia celular com CTM adultas no processo de cicatrização de lesões ulcerosas.

O tecido adiposo e respectiva FVE, rica em CTM, tem sido empregado, em associação com PRP, para o tratamento de úlceras pós-traumáticas dos membros inferiores e os resultados indicam um aumento significante da reepitelização quando comparado com grupos controles não tratados (CERVELLI; GENTILE; GRIMALDI, 2009; CERVELLI et al., 2011). Neste contexto, coletivamente, os estudos pré-clínicos e triagens têm demonstrado que o tratamento com CTM, por via subcutânea ou tópica, associadas a veículos como colágeno, cola de fibrina, PRP ou outros biomateriais aceleram a cicatrização, restauram anexos epidérmicos e promovem a angiogênese no leito de úlceras cutâneas, sem efeitos adversos significantes (ISAKSON et al., 2015).

Em resumo, há vários relatos na literatura de experimentos animadores no que se refere à regeneração de úlceras cutâneas sob os mecanismos de ação das CTM, em especial as CT-TA, que tem potencial para promover a proliferação, síntese de colágeno, angiogênese e remodelamento tecidual (YANG et al., 2013). O processo de regeneração da pele envolve um mecanismo complexo de remodelação tecidual, mediante reparo cartilaginoso, glandular-sebáceo, folicular e vascular (METCALFE; FERGUSON, 2008), desta forma, a aplicação de vários fatores de crescimento associados à terapia celular com CTM tem potencial para estimular a cicatrização de lesões cutâneas (BLANTON et al., 2009).

Tais resultados e perspectivas permitem inferir que o emprego de CTM, embora ainda nos primórdios das pesquisas, representa uma alternativa extremamente promissora e situa-se como uma das terapias celulares que 
deverá, brevemente, estar incorporada entre as práticas clínicas rotineiras para o tratamento de lesões cutâneas crônicas. 


\section{OBJETIVOS}

\subsection{Objetivo geral}

- Analisar a segurança e eficácia da aplicação tópica de plasma rico em plaquetas (PRP) associado a células-tronco mesenquimais do tecido adiposo (CT-TA) em úlceras cutâneas crônicas de pacientes diabéticos.

\subsection{Objetivos específicos}

- Avaliar diferentes protocolos e padronizar uma metodologia para produção de PRP na forma de gel.

- Investigar a influência do PRP sobre a proliferação e migração de CTTA in vitro.

- Investigar a influência do PRP e meio condicionado (MC) de CT-TA sobre a proliferação e migração de fibroblastos e queratinócitos in vitro.

- Avaliar a segurança do procedimento em úlceras cutâneas crônicas de pacientes diabéticos.

- Avaliar a eficácia do procedimento, por meio de análise da evolução e resolução das úlceras crônicas em pacientes diabéticos. 


\section{MATERIAL E MÉTODOS}

\subsection{Obtenção dos materiais biológicos}

\subsubsection{Obtenção e criopreservação do PRP}

O PRP foi obtido a partir de uma $(n=1)$ bolsa/unidade de sangue total $(450 \mathrm{~mL})$ proveniente de uma $(\mathrm{n}=1)$ doadora voluntária, com 23 anos de idade, saudável e aprovada pela triagem de rotina para doação de sangue no Hemocentro da UNICAMP (sorologia negativa para HIV, HTLV I e II, Chagas, Sífilis, Hepatite B e C). Após ciência do estudo e concordância com a doação para a pesquisa, houve a assinatura do Termo de Consentimento Livre e Esclarecido (TCLE), Anexo A, avalizando a concessão do material biológico para aplicação neste estudo.

A unidade de sangue total foi mantida com anticoagulante CPDA-1 (Citrato, Fosfato, Dextrose e Adenina), à temperatura ambiente $\left(22^{\circ} \mathrm{C}\right)$, com o propósito da proteção plaquetária, em laboratório do Hemocentro da UNICAMP. Durante este período, amostras da unidade de sangue total foram submetidas a testes imunohematológicos relacionados ao controle de qualidade de rotina do material biológico. Após 48 horas da coleta, a unidade de sangue total foi liberada e transportada ao Laboratório de Cultura de Células da Pele - CIPED - FCM - UNICAMP para processamento.

A unidade de sangue total foi fracionada em tubos de $50 \mathrm{~mL}$ (Sarsted, Nümbrecht, Alemenaha). Após avaliação de diferentes protocolos de centrifugação, em acordo com o item 3.2.1, os tubos foram processados para obtenção do PRP conforme o protocolo proposto por Jo e colaboradores (2013). Em resumo, os tubos foram centrifugados a $900 \mathrm{~g}$ por 5 minutos a 16 ${ }^{\circ} \mathrm{C}$ para separação do plasma. O plasma sobrenadante foi recolhido e centrifugado a $1500 \mathrm{~g}$ por 15 minutos e $16{ }^{\circ} \mathrm{C}$ para concentração plaquetária. Após a segunda centrifugação, o plasma pobre em plaquetas (PPP) e o plasma médio em plaquetas (PMP), equivalente aos $2 / 3$ superiores de plasma no tubo, foram recolhidos e preservados a $-20{ }^{\circ} \mathrm{C}$. O plasma remanescente $\mathrm{e}$ sobrenadante ao botão plaquetário foi recolhido, rotulado como plasma do PRP e estocado a $-20{ }^{\circ} \mathrm{C}$. Cada botão de plaquetas foi ressuspenso em $5 \mathrm{~mL}$ de 
uma solução de $6 \%$ de dimetilsulfóxido (DMSO) em PPP e criopreservado em tubos tipo Falcon de $15 \mathrm{~mL}$ (Sarstedt, Nümbrecht, Alemenaha) a $-80^{\circ} \mathrm{C}$ para uso posterior nos experimentos. O processamento acima descrito é ilustrado na Figura 3.

Figura 3 - Processamento da unidade de sangue total para obtenção da fração plasmática e criopreservação.

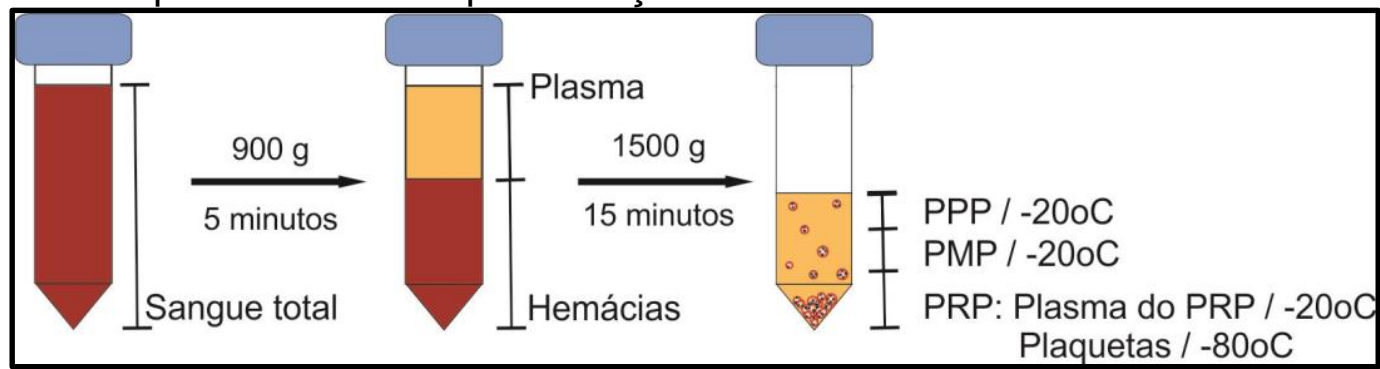

\subsubsection{Obtenção do tecido adiposo}

O tecido adiposo foi obtido de indivíduos $(n=6)$ com idade entre 30 e 45 anos, submetidos à cirurgia bariátrica no Centro Cirúrgico do Hospital das Clínicas da UNICAMP. Em data anterior à cirurgia, os pacientes e familiares foram informados sobre a pesquisa e convidados a participar do estudo, mediante doação de tecido adiposo, recolhido durante procedimento bariátrico. Os pacientes e quatro familiares, após esclarecimento e concordância, assinaram o TCLE, Anexo B, autorizando a doação do tecido adiposo.

Durante a cirurgia bariátrica, foi coletado de cada paciente, um fragmento de tecido adiposo da região abdominal, próxima à superfície cutânea, com peso entre 7 - $15 \mathrm{~g}$. Os fragmentos foram imersos em tampão fosfato DPBS (Dulbecco's Phosphate-Buffered Saline), pH 7,4, à temperatura ambiente, até processamento para isolamento das CT-TA, por período não superior a 24 horas.

\subsubsection{Obtenção das amostras de pele}

As amostras de pele foram obtidas de indivíduos $(n=6)$ com idade superior a 60 anos, submetidos a procedimento de blefaroplastia, realizado no 
Centro Cirúrgico Ambulatorial do Hospital das Clínicas da UNICAMP. Antes do procedimento cirúrgico, cada paciente e acompanhante foram esclarecidos sobre a pesquisa e convidados a participar do estudo, mediante doação de parte do fragmento das pálpebras removido durante a blefaroplastia, normalmente destinado ao descarte. Após concordância com a doação, paciente e acompanhante assinaram o TCLE, Anexo C, autorizando a doação do material biológico. Os fragmentos de tecido palpebral foram conduzidos ao Laboratório de Cultura de Células da Pele - CIPED - FCM - UNICAMP, imersos em tampão fosfato DPBS, pH 7,4, e armazenados, por período não superior a 24 horas, em geladeira, à temperatura de $8^{\circ} \mathrm{C}$, até processamento.

\subsection{Padronização da produção do PRP}

\subsubsection{Avaliação dos protocolos de centrifugação}

Foram examinados e avaliados seis protocolos de centrifugação para obtenção do PRP, encontrados na literatura. Três protocolos propõem a obtenção do PRP mediante uma etapa de centrifugação (ANITUA et al., 2008; ANITUA; TROYA; ORIVE, 2013; SCARANTO, 2002;) e três protocolos assumem diferentes metodologias para a concentração plaquetária por meio de duas etapas de centrifugação (SCARANTO, 2002; VENDRAMIN; FRANCO; FRANCO, 2009; JO et al., 2013), em acordo com a Tabela 4.

Tabela 4 - Protocolos de centrifugação para obtenção do PRP.

\begin{tabular}{|c|c|c|c|c|c|c|}
\hline Protocolo & $\begin{array}{c}\text { Número de } \\
\text { centrifugações }\end{array}$ & $\begin{array}{c}\text { Força } \\
\text { centrífuga } \\
\text { (g) }-\mathrm{PC}^{\star}\end{array}$ & $\begin{array}{l}\text { Tempo } \\
(\min )- \\
\text { PC }^{\star}\end{array}$ & $\begin{array}{c}\text { Força } \\
\text { centrífuga } \\
\text { (g) }- \text { SC }^{\star \star}\end{array}$ & $\begin{array}{c}\text { Tempo } \\
(\min )- \\
\text { SC }^{\star *}\end{array}$ & Referência \\
\hline I & 1 & 160 & 10 & - & - & Scaranto, 2002 \\
\hline II & 1 & 460 & 8 & - & - & Anitua et al., 2008 \\
\hline III & 1 & 580 & 8 & - & - & Anitua et al., 2013 \\
\hline IV & 2 & 160 & 10 & 1050 & 10 & Scaranto, 2002 \\
\hline V & 2 & 400 & 10 & 800 & 10 & $\begin{array}{c}\text { Vendramin et al. } \\
2009\end{array}$ \\
\hline VI & 2 & 900 & 5 & 1500 & 15 & Jo et al., 2013 \\
\hline
\end{tabular}


Para a realização dos diferentes protocolos, cada um em triplicata, 90 $\mathrm{mL}$ da unidade de sangue total, antes da criopreservação descrita no item 3.1.1, foram fracionados em 18 tubos tipo Falcon de $15 \mathrm{~mL}$ (Sarstedt), contendo, portanto, $5 \mathrm{~mL}$ de sangue total por tubo (Figura $4 \mathrm{~A}$.).

Nos protocolos I, II e III, após a centrifugação, a fração correspondente ao PRP está situada entre $0,5-1 \mathrm{~cm}$ acima do buffy coat, ou creme leucocitário na interface entre a fração vermelha de hemácias e o plasma sobrenadante, conforme a Figura $4 \mathrm{~B}, \mathrm{C}$ e D.

Figura 4 - Obtenção de PRP por meio de uma etapa de centrifugação.

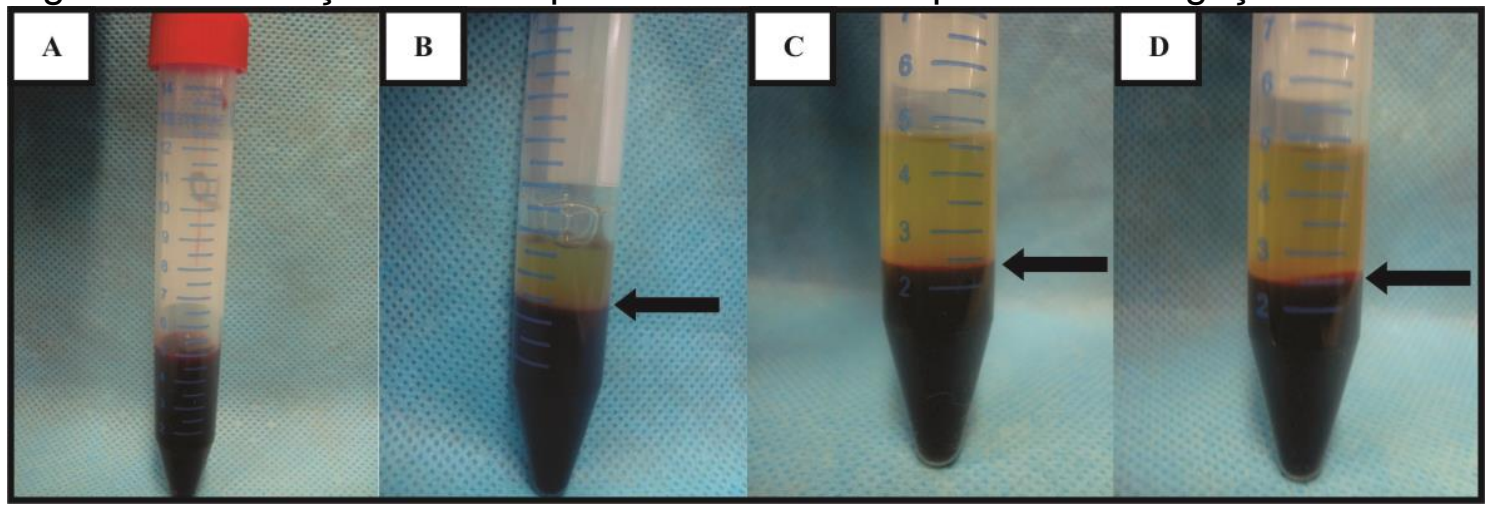

A) $5 \mathrm{~mL}$ de sangue total. Separação do plasma após execução do protocolo I (B), II (C) e III (D). As setas indicam o buffy coat, ou creme leucocitário disposto entre a fração rica em hemácias (porção inferior do tubo) e o PRP, imediatamente acima.

Nos protocolos com dois estágios de centrifugação (IV, $\mathrm{V}$ e $\mathrm{VI}$ ), após a primeira centrifugação (Figura 5. A, B e C), o plasma acima do buffy coat foi recolhido e submetido à segunda centrifugação. O PRP é obtido a partir da retirada de 2/3 do plasma situado na porção superior, correspondente ao PPP e plasma médio em plaquetas (PMP). O botão plaquetário é ressuspenso no 1/3 do plasma restante no tubo, situado na porção inferior, e o PRP é obtido, conforme ilustra a Figura 5. 
Figura 5 - Obtenção de PRP por meio de duas etapas de centrifugação.

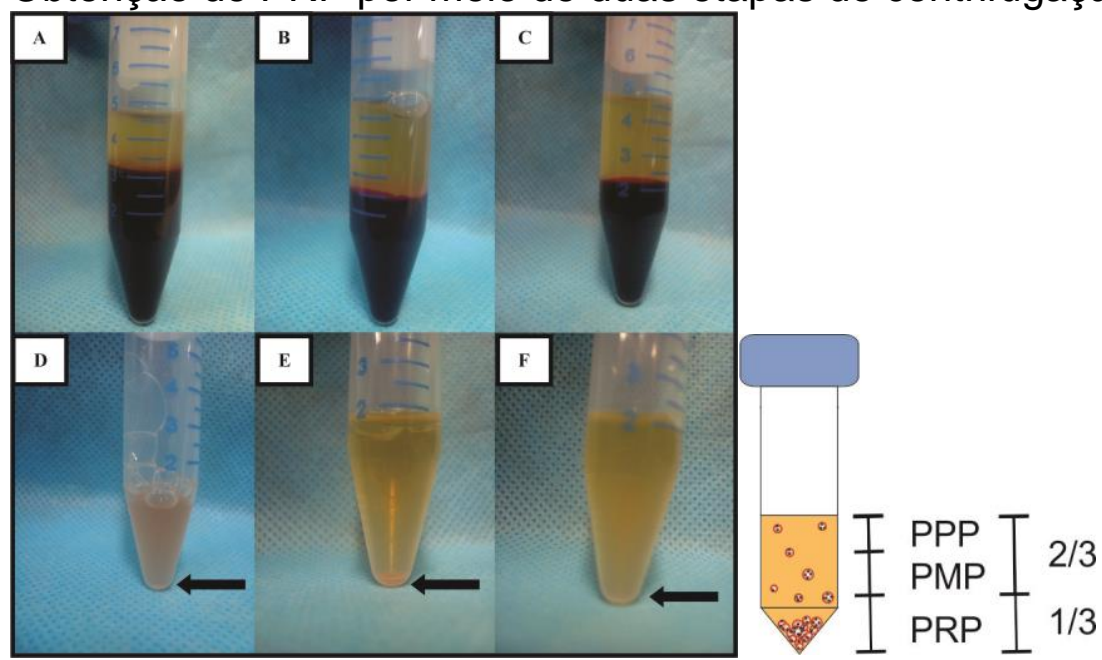

Separação do plasma em acordo com o protocolo IV (A), V (B) e VI (C). Concentração das plaquetas e formação do PRP segundo o protocolo IV (D), V (E) e VI (F). As setas indicam os botões plaquetários e o desenho ilustra o fracionamento do plasma.

\subsubsection{Quantificação dos componentes sanguíneos}

As plaquetas, leucócitos, neutrófilos e eritrócitos foram quantificados em analisador hematológico Sysmex XE-500 (Sysmex Corporation, Kobe, Japão) a partir de amostras coletadas antes (sangue total - ST) e após as centrifugações (PRP).

\subsubsection{Eficiência na recuperação do plasma e das plaquetas}

A eficiência de recuperação do plasma $\left(E_{(\mathrm{p}) \mathrm{PS}}\right)$, após centrifugação para separação plasmática, é calculada em acordo com a Equação I.

$$
E_{(\mathrm{pl}) \mathrm{PS}}=\frac{V_{(\mathrm{pl}) \mathrm{PS}} \mathrm{x}}{V_{(\mathrm{pl}) \mathrm{ST}}} 100
$$

Eq. I.

Onde $V_{(p) P S}$ é o volume do plasma obtido após centrifugação, igual ao plasma sobrenadante (PS) e $V_{(\mathrm{pl}) \text { ST }}$ é o volume de plasma no sangue total (ST), estimado em acordo com a Equação II.

$$
V_{(p) S T}=V_{S T} \times(1-H) \quad \text { Eq. II. }
$$


Sendo Vst o volume de sangue total, pré-centrifugação, e $\mathrm{H} O$ hematócrito.

Com o propósito de validar a eficiência da centrifugação para concentração das plaquetas no PRP, a eficiência da recuperação plaquetária, $E_{(p t) P R P}$, foi calculada em acordo com a Equação III.

$$
E_{(\mathrm{pt}) \mathrm{PRP}}=\frac{N_{(\mathrm{pt}) \mathrm{PRP}} \times V_{(\mathrm{pl}) \mathrm{PRP}}}{N_{(\mathrm{pt}) \mathrm{ST}} \times V_{(\mathrm{pl}) \mathrm{ST}}} \times 100
$$

Eq. III.

Onde $N_{(\mathrm{pt}) \text { PRP }}$ é a concentração de plaquetas no PRP, $N_{(\mathrm{pt}) \mathrm{ST}}$ a

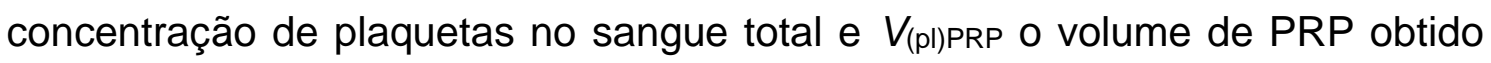
após centrifugação.

O fator de concentração plaquetária, $F_{\mathrm{CP}}$, foi calculado em função da Equação IV.

$$
F_{\mathrm{CP}}=\frac{N_{(\mathrm{pt}) \mathrm{PRP}}}{N_{(\mathrm{pt}) \mathrm{ST}}} \times 100
$$

Eq. IV.

\subsection{Padronização da produção do PRP em gel}

\subsubsection{Avaliação do pH após ativação plaquetária}

Para a formação de PRP na forma de gel foi adicionado solução de gluconato de cálcio a $10 \%$ nos volumes $25 \mu \mathrm{L}, 50 \mu \mathrm{L}, 100 \mu \mathrm{L}, 200 \mu \mathrm{L}$ e $300 \mu \mathrm{L}$ para cada $1 \mathrm{~mL}$ de PRP. Após a ativação, $2 \mathrm{~mL}$ de PRP ativados com diferentes volumes de gluconato de cálcio foram acrescentados a $10 \mathrm{~mL}$ de água destilada para aferição do pH em pHmêtro digital (Becton Dickinson, New Jersey, EUA).

\subsubsection{Ensaio da formação de gel (gelificação)}

Foram adicionados $25 \mu \mathrm{L}, 50 \mu \mathrm{L}, 100 \mu \mathrm{L}, 200 \mu \mathrm{L}$ ou $300 \mu \mathrm{L}$ de gluconato de cálcio a $10 \%$ para cada $1 \mathrm{~mL}$ de PRP, em triplicata. Antes da gelificação, o 
PRP ativado foi colocado em placas de Petri descartáveis (Becton Dickinson, Nova Jersey, EUA) para formação do PRP em forma de filme, processo que ocorre em cerca de 2 a 3 minutos, à temperatura ambiente. No decorrer do tempo, o gel contrai-se e libera fração aquosa, cujo volume foi medido após $1 \mathrm{~h}$, $2 \mathrm{~h}$, 3h e $6 \mathrm{~h}$ da gelificação (adaptado de JO et al., 2013).

\subsection{Isolamento e cultura das CT-TA}

Para o isolamento das CT-TA foi empregado o protocolo proposto por Bunnell e colaboradores (2008), com pequenas modificações. Os fragmentos de tecido adiposo foram lavados 2 vezes com solução de tampão fosfato DPBS, pH 7,4, suplementada com $1 \%$ de penicilina, estreptomicina e Lglutamina (Gibco, Nova York, EUA) para desinfecção. O tecido adiposo, após remoção dos debris, foi colocado em placa de Petri descartável contendo 10 $\mathrm{mL}$ de solução de colagenase tipo I (Sigma-Aldrich, Missouri, EUA) a 0,075\% e seccionado com tesoura e pinça até a obtenção de fragmentos de tecido adiposo com aproximadamente 2-3 $\mathrm{mm}^{3}$. A amostra foi colocada em tubo tipo Falcon de $50 \mathrm{~mL}$, homogeneizada com pipeta estéril de $25 \mathrm{~mL}$ (Sarstedt, Nümbrecht, Alemanha) e incubada em banho-maria a $37^{\circ} \mathrm{C}$ com agitação por 30 minutos para a digestão enzimática.

Após o período de incubação, a colagenase foi neutralizada com $10 \mathrm{~mL}$ de meio de cultura M199 (Gibco, Nova York, EUA), suplementado com 10\% de soro fetal bovino - SFB (Gibco, Nova York, EUA) e 1\% de penicilina, estreptomicina e L-glutamina e novamente homogeneizada com pipeta de 25 $\mathrm{mL}$. A amostra foi centrifugada a $450 \mathrm{~g}$ por 5 minutos a $20^{\circ} \mathrm{C}$ para obtenção da fração estromal. $O$ tubo foi agitado vigorosamente para homogeneizar 0 pellet e misturar as células, completando a separação das células estromais e adipócitos primários. $\mathrm{O}$ tubo foi novamente centrifugado a $450 \mathrm{~g}$ por 5 minutos a $20{ }^{\circ} \mathrm{C}$. O óleo e o meio com colagenase foram removidos, o pellet ressuspenso em $1 \mathrm{~mL}$ de tampão de lise $\left(0,1 \%\right.$ de $\mathrm{KHCO}_{3}, 0,82 \%$ de $\mathrm{NH}_{4} \mathrm{Cl}$ e $0,0037 \%$ de EDTA $4 \mathrm{Na}$ ) e incubado em gelo por 10 minutos.

As células foram lavadas com $20 \mathrm{~mL}$ de tampão fosfato DPBS, $\mathrm{pH} 7,4$, suplementado com $1 \%$ de penicilina, estreptomicina e L-glutamina e 
centrifugadas a $450 \mathrm{~g}$ por 5 minutos a $20^{\circ} \mathrm{C}$. O sobrenadante foi removido e 0 pellet celular ressuspenso em $3 \mathrm{~mL}$ de meio de cultura M199, suplementado com $10 \%$ de SFB e $1 \%$ de penicilina, estreptomicina e L-glutamina. A suspensão celular foi filtrada em filtro Cell Strainer $70 \mu \mathrm{m}$ (Becton Dickinson, Nova Jersey, EUA). O filtrado foi semeado em garrafas de cultura T25 (Sarstedt, Nümbrecht, Alemanha) na proporção de $1 \mathrm{~g}$ de tecido adiposo para cada $6 \mathrm{~cm}^{2}$ de área. As células foram mantidas em incubadora de $\mathrm{CO}_{2}$ a $37{ }^{\circ} \mathrm{C}$ e $5 \%$ de $\mathrm{CO}_{2}$. Etapas do protocolo são ilustradas na Figura 6.

Figura 6 - Metodologia para isolamento das CT-TA.

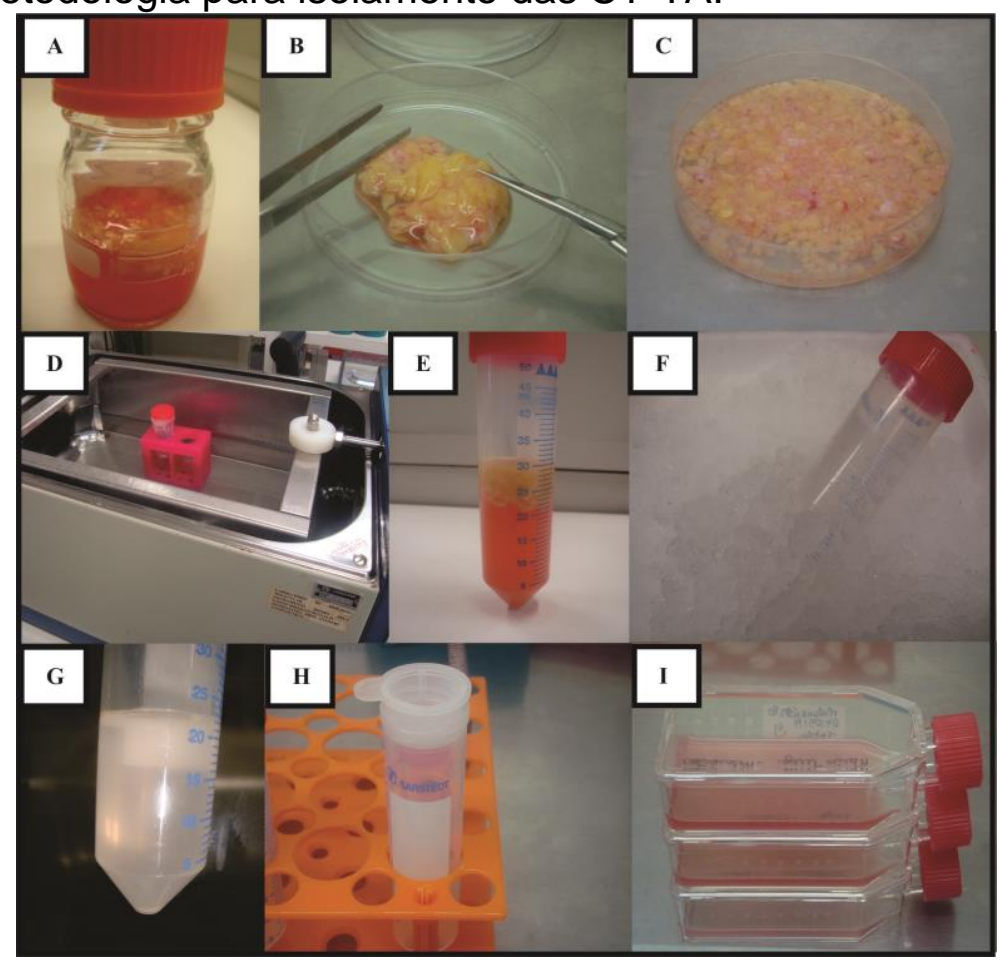

A) Desinfecção do tecido adiposo. B e C) Fragmentação do tecido adiposo. D) Digestão enzimática com colagenase em banho-maria a $37^{\circ} \mathrm{C}$. E) Sedimentação das células estromais pós centrifugação. F) Incubação das células em tampão de lise. G) Lavagem das células em tampão fosfato DPBS. H) Filtração da fração estromal em filtro de $70 \mu \mathrm{m}$. I) Células semeadas em garrafas T25.

Após atingir 80-90\% de confluência na garrafa de cultura, as células foram tripsinizadas até a terceira passagem. Em resumo, a superfície foi lavada uma vez com solução de tampão fosfato DPBS, $\mathrm{pH} 7,4$, suplementada com $1 \%$ de penicilina, estreptomicina e L-glutamina. Foram adicionados 0,12 $\mathrm{mL}$ de Tryple $^{\mathrm{TM}}$ (Gibco, Nova York, EUA) por $\mathrm{cm}^{2}$ de área cultivada (tripsinização). Os frascos foram mantidos em incubadora de $\mathrm{CO}_{2}$ a $37^{\circ} \mathrm{C}$ e $5 \%$ de $\mathrm{CO}_{2}$ por 5 
minutos para o desprendimento celular. O Tryple ${ }^{\mathrm{TM}}$ (Gibco, Nova York, EUA) foi diluído com igual volume de meio de cultura M199. A suspensão celular foi centrifugada a $400 \mathrm{~g}$ por 10 minutos a $20^{\circ} \mathrm{C}$. O sobrenadante foi removido, o pellet ressuspenso em meio de cultura suplementado e semeado em área duas vezes maior que a área da passagem anterior.

\subsubsection{Preparo do meio condicionado}

Células-tronco mesenquimais do tecido adiposo em terceira passagem, em confluência de 80 - 90\%, cultivadas em garrafas T75 (Sarstedt, Nümbrecht, Alemanha), foram utilizadas para a obtenção do meio condicionado (MC). A superfície celular foi lavada duas vezes com tampão fosfato DPBS, $\mathrm{pH} 7,4$, suplementado com $1 \%$ de penicilina, estreptomicina e L-glutamina e $12 \mathrm{~mL}$ de meio M199 suplementado com 1\% de penicilina, estreptomicina e L-glutamina foram adicionados em cada garrafa T75. As garrafas foram incubadas em estufa de $\mathrm{CO}_{2}$ a $37{ }^{\circ} \mathrm{C}$ e $5 \%$ de $\mathrm{CO}_{2}$. Após 48 horas, o meio de cultura foi aspirado e centrifugado a $300 \mathrm{~g}$ por 10 minutos a $20^{\circ} \mathrm{C}$ para remoção dos debris. O sobrenadante corresponde ao MC (LEE et al., 2012).

\subsubsection{Imunofenotipagem das CT-TA}

A imunofenotipagem das CT-TA foi realizada por citometria de fluxo, com um citômetro de 4 cores FACSCalibur (Becton Dickinson, Nova Jersey, EUA). Uma amostra da população de CT-TA, em terceira passagem, foi marcada com os anticorpos monoclonais CD73 (Becton Dickinson, Nova Jersey, EUA), CD90 (Becton Dickinson, Nova Jersey, EUA), CD105 (Biolegend, Londres, Reino Unido), bem como os marcadores de exclusão CD34 (Becton Dickinson, Nova Jersey, EUA), HLA-DR (Biolegend, Londres, Reino Unido), CD19 (Biolegend, Londres, Reino Unido), CD11b (Exbio, Vestec, República Checa) e CD45 (Becton Dickinson, Nova Jersey, EUA). A viabilidade da amostra foi verificada com Kit Live and Dead (Invitrogen, Nova York, EUA). O painel de marcadores selecionados está em acordo com o proposto pela Sociedade Internacional de Terapia Celular (DOMINICI et al., 2006). 


\subsubsection{Verificação do potencial de diferenciação das CT-TA}

\subsubsection{Diferenciação adipogênica}

Com o propósito da diferenciação adipogênica, CT-TA em terceira passagem foram semeadas em placa de 12 poços, na densidade de $1 \times 10^{4}$ células $/ \mathrm{cm}^{2}$. Após quatro dias de cultivo em meio M199, suplementado com 10 $\%$ de SFB e $1 \%$ de penicilina, estreptomicina e L-glutamina, as células foram lavadas com tampão fosfato DPBS e cultivadas com meio do kit de diferenciação adipogênica StemPro (Cibco, Nova York, EUA), durante 7 dias, em acordo com a metodologia proposta pelo fabricante. A diferenciação adipogênica foi confirmada mediante coloração das células com Oil Red $O$ (Sigma-Aldrich, Missouri, EUA).

\subsubsection{Diferenciação condrogênica}

Com o propósito da diferenciação condrogênica, CT-TA em terceira passagem foram semeadas em placa de 12 poços, na concentração de 1,6 $\mathrm{x}$ $10^{7}$ células $/ \mathrm{mL}$ em três gotas de $5 \mu \mathrm{L}$ e incubadas em estufa de $\mathrm{CO}_{2}$. Após duas horas de incubação em meio M199, suplementado com 10\% de SFB e $1 \%$ de penicilina, estreptomicina e L-glutamina, as células foram cultivadas com meio do kit para diferenciação condrogênica StemPro (Cibco, Nova York, EUA), durante 14 dias, em acordo com a metodologia proposta pelo fabricante. A diferenciação condrogênica foi confirmada mediante coloração das células com Alcian Blue (Sigma-Aldrich, Missouri, EUA).

\subsubsection{Diferenciação osteogênica}

Com a finalidade da diferenciação osteogênica, CT-TA em terceira passagem foram semeadas em placa de 12 poços, na densidade de $5 \times 10^{3}$ células $/ \mathrm{cm}^{2}$. Após quatro dias de cultivo em meio M199, suplementado com 10 $\%$ de SFB e $1 \%$ de penicilina, estreptomicina e L-glutamina, as células foram lavadas com tampão fosfato DPBS e cultivadas com meio do kit de diferenciação osteogênica StemPro (Gibco, Nova York, EUA), durante 21 dias, 
em acordo com a metodologia proposta pelo fabricante. A diferenciação osteogênica foi confirmada mediante coloração das células com Alizarin Red (Sigma-Aldrich, Missouri, EUA).

\subsection{Isolamento e cultura de fibroblastos e queratinócitos}

As amostras de pele $(n=6)$ foram dispostas em placas de Petri com tripsina $0,025 \%$ + EDTA $0,1 \%$ e fracionados com tesoura e pinça em fragmentos com cerca de $2 \mathrm{~mm}^{3}$. A suspensão de tripsina com os fragmentos de pele foram incubados em estufa de cultura, a $37^{\circ} \mathrm{C}$ e $5 \%$ de $\mathrm{CO}_{2}$, por 3 horas. A tripsina foi neutralizada com igual volume de meio M199, suplementado com $10 \%$ de SFB e $1 \%$ de penicilina, estreptomicina e Lglutamina. A suspensão celular, contendo as células dérmicas e epidérmicas, foi filtrada em filtro Cell Strainer $40 \mu \mathrm{m}$ (BD, Nova Jersey, EUA) e o filtrado centrifugado a $400 \mathrm{~g}$ por 10 minutos a $20^{\circ} \mathrm{C}$. Após a contagem das células em câmara de Neubauer, as células foram semeadas em frascos de cultura T25, na densidade de $1,0 \times 10^{5}$ células $/ \mathrm{cm}^{2}$ e incubadas a $37^{\circ} \mathrm{C}$ e $5 \%$ de $\mathrm{CO}_{2}$. As células foram cultivadas em meio M199, suplementado com 10\% de SFB e 1\% de penicilina, estreptomicina e L-glutamina para isolamento de fibroblastos ou em Kit para seleção de queratinócitos Keratinocyte - Serum Free Medium (Gibco, Nova York, EUA) suplementado com 10\% de SFB e 1\% de penicilina, estreptomicina e L-glutamina para isolamento dos queratinócitos. A Figura 7 ilustra etapas do protocolo para obtenção de fibroblastos e queratinócitos a partir de fragmentos de pele. 
Figura 7 - Etapas metodológicas para obtenção de fibroblastos e queratinócitos a partir de fragmentos de pele.

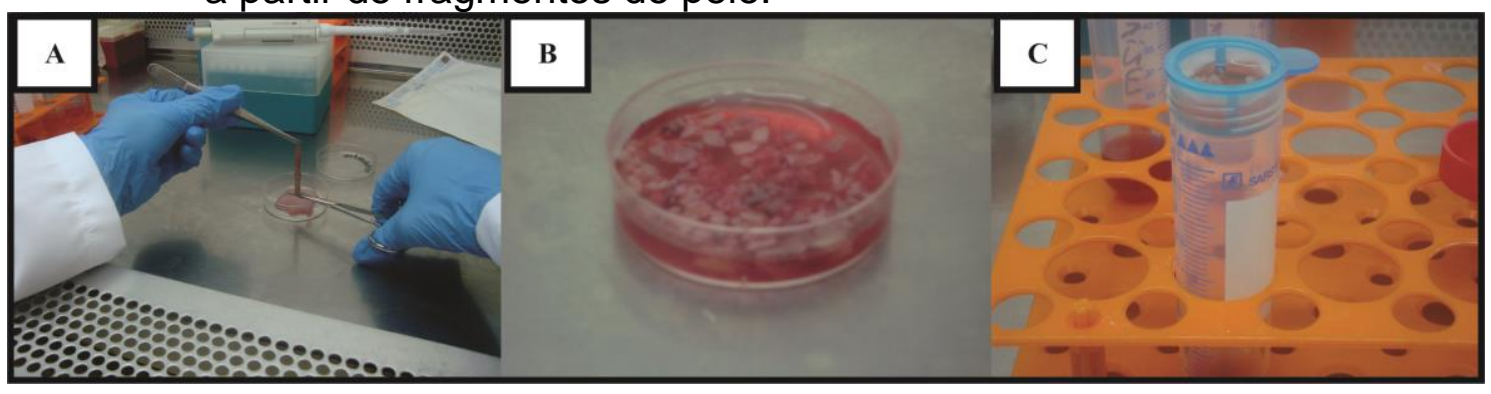

A) Fragmentação das amostras de pele. B) Separação da derme (sedimentada) e epiderme (em suspensão) após digestão enzimática com tripsina. C) Filtração da suspensão celular em filtro de $40 \mu \mathrm{m}$ pré-cultivo.

Após atingirem $80-90 \%$ de confluência celular, as culturas de fibroblastos e queratinócitos foram submetidas à tripsinizações até a terceira passagem. Em resumo, a superfície foi lavada uma vez com solução de tampão fosfato DPBS, pH 7,4, suplementada com $1 \%$ de penicilina, estreptomicina e L-glutamina. Foram adicionados $0,12 \mathrm{~mL}$ de tripsina a $0.025 \%$ (Gibco, Nova York, EUA) por $\mathrm{cm}^{2}$ de área cultivada. Os frascos foram incubados em estufa de $\mathrm{CO}_{2}$ a $37{ }^{\circ} \mathrm{C}$ e $5 \%$ de $\mathrm{CO}_{2}$ por 5 minutos para $\mathrm{O}$ desprendimento celular. A tripsina foi neutralizada com meio de cultura M199, suplementado com $10 \%$ de SFB e $1 \%$ de penicilina, estreptomicina e Lglutamina e a suspensão celular centrifugada a $400 \mathrm{~g}$ por 10 minutos a $20^{\circ} \mathrm{C}$. $\mathrm{O}$ sobrenadante foi removido, o pellet ressuspenso em meio de cultura suplementado e semeado em área duas vezes maior que a área da passagem anterior. A partir da primeira passagem, as culturas de queratinócitos foram cultivadas sem suplementação com SFB.

\subsection{Ensaio de proliferação}

O ensaio colorimétrico com kit CCK-8 (Dojindo, Japão) é baseado na conversão do sal hidrossolúvel, amarelo claro, WST-8 (tetrazólio), via mediador de elétrons 1-Metoxi PMS, em um produto alaranjado, WST-8 formazan, por meio da atividade de NADP e NADPH das células. Desta forma, a quantidade de WST-8 formazan depende da atividade das desidrogenases celulares e pode ser utilizada para determinar a viabilidade e proliferação celular. A 
proporção do produto WST-8 formazan pode ser determinada por leitura da absorbância, na densidade ótica de $450 \mathrm{~nm}$.

\subsection{Avaliação da proliferação de CT-TA na presença de PRP}

Células-tronco mesenquimais em terceira passagem foram semeadas em placas de 96 poços (Becton Dickinson, Nova Jersey, EUA) na concentração de $2 \times 10^{3}$ células/poço, em seis amostras (sextuplicata), e cultivadas em meio M199 suplementado com 10\% de SFB e 1\% de penicilina, estreptomicina e Lglutamina. Após 24 horas, o meio foi removido e substituído por meio de cultura M199 suplementado com 0\% (branco), 10\%, 25\%, 50\% e 100\% de PRP (ativado com $25 \mu \mathrm{L}$ de gluconato de cálcio a $10 \%$ para cada $1000 \mu \mathrm{L}$ de PRP) ou $10 \%$ de SFB e $1 \%$ de penicilina, estreptomicina e L-glutamina. A proliferação celular foi verificada após 24 e 48 horas de incubação, mediante adição de $10 \mu \mathrm{L}$ do reagente CCK-8 (Dojindo), em acordo com a metodologia proposta pelo fabricante e a absorbância foi medida a $450 \mathrm{~nm}$ para análise.

\subsection{Avaliação da proliferação de células da pele na presença de PRP e meio condicionado}

Fibroblastos e queratinócitos, em terceira passagem, foram semeados em placas de 96 poços (Becton Dickinson, Nova Jersey, EUA) na concentração de $2 \times 10^{3}$ células/poço, em sextuplicata, e cultivados em meio M199 suplementado com $10 \%$ de SFB e $1 \%$ de penicilina, estreptomicina e Lglutamina (fibroblastos) e meio Keratinocyte-SFM suplementado com $10 \%$ de SFB e 1\% de penicilina, estreptomicina e L-glutamina (queratinócitos). Após 24 horas, o meio foi removido e substituído por meio de cultura M199 (fibroblastos) ou meio Keratinocyte-SFM (queratinócitos) suplementados com 0\% (branco), $10 \%, 25 \%, 50 \%$ e $100 \%$ de PRP, $10 \%, 25 \%, 50 \%$ e $100 \%$ de MC, $10 \%$ de PRP + $10 \%$ de MC, $25 \%$ de PRP $+25 \%$ de MC, $50 \%$ de PRP $+50 \%$ de MC ou $10 \%$ de SFB. Todos os meios suplementados com $1 \%$ de penicilina, estreptomicina e L-glutamina. A proliferação celular foi verificada após 24 e 48 horas de incubação, mediante adição de $10 \mu \mathrm{L}$ do reagente CCK-8, em acordo com a metodologia proposta pelo fabricante e a absorbância foi medida a $450 \mathrm{~nm}$. 


\subsection{Ensaio de migração}

A migração celular foi verificada mediante scratch assay, conforme proposto por Liang e colaboradores (2007). Para este ensaio, fibroblastos foram semeados em placas de 12 poços, na concentração de $1 \times 10^{5}$ células $/ \mathrm{mL}$, em triplicata, e cultivados em meio M199 com 0\% (branco), 10\% de PRP, $10 \%$ de MC, $10 \%$ de PRP $+10 \%$ de MC ou $10 \%$ de SFB. Células-tronco mesenquimais foram semeadas em placas de 12 poços, na concentração de 1 x $10^{5}$ células $/ \mathrm{mL}$, em triplicata, e cultivadas em meio M199 com 0\% (branco), $10 \%$ de PRP ou $10 \%$ de SFB. Com o auxílio de uma pipeta P200, um traço foi desenhado no fundo de uma placa com células confluentes em monocamada. Imagens foram feitas sobre o espaço aberto no plástico e, desta forma, a migração das células foi acompanhada, após 24 e 48 horas, por meio do cálculo da área aberta com auxílio do software Image J. O ensaio mimetiza a migração celular durante o processo de cicatrização in vivo.

\subsection{Desenho experimental do estudo clínico}

O presente estudo corresponde a uma análise clínica prospectiva para avaliação da segurança e eficácia referente ao emprego de PRP sob a forma gel associado à CT-TA em úlceras cutâneas crônicas de pacientes diabéticos. Todos os tipos celulares são obtidos do próprio paciente, caracterizando um procedimento integralmente autólogo. A Figura 8 ilustra o desenho do estudo clínico. 
Figura 8 - Delineamento experimental do estudo clínico relativo à terapia celular em úlceras cutâneas crônicas com implantes de CT-TA associadas a PRP.

\section{Terapia celular em úlceras crônicas com implante de células-tronco mesenquimais associadas a plasma rico em plaquetas}
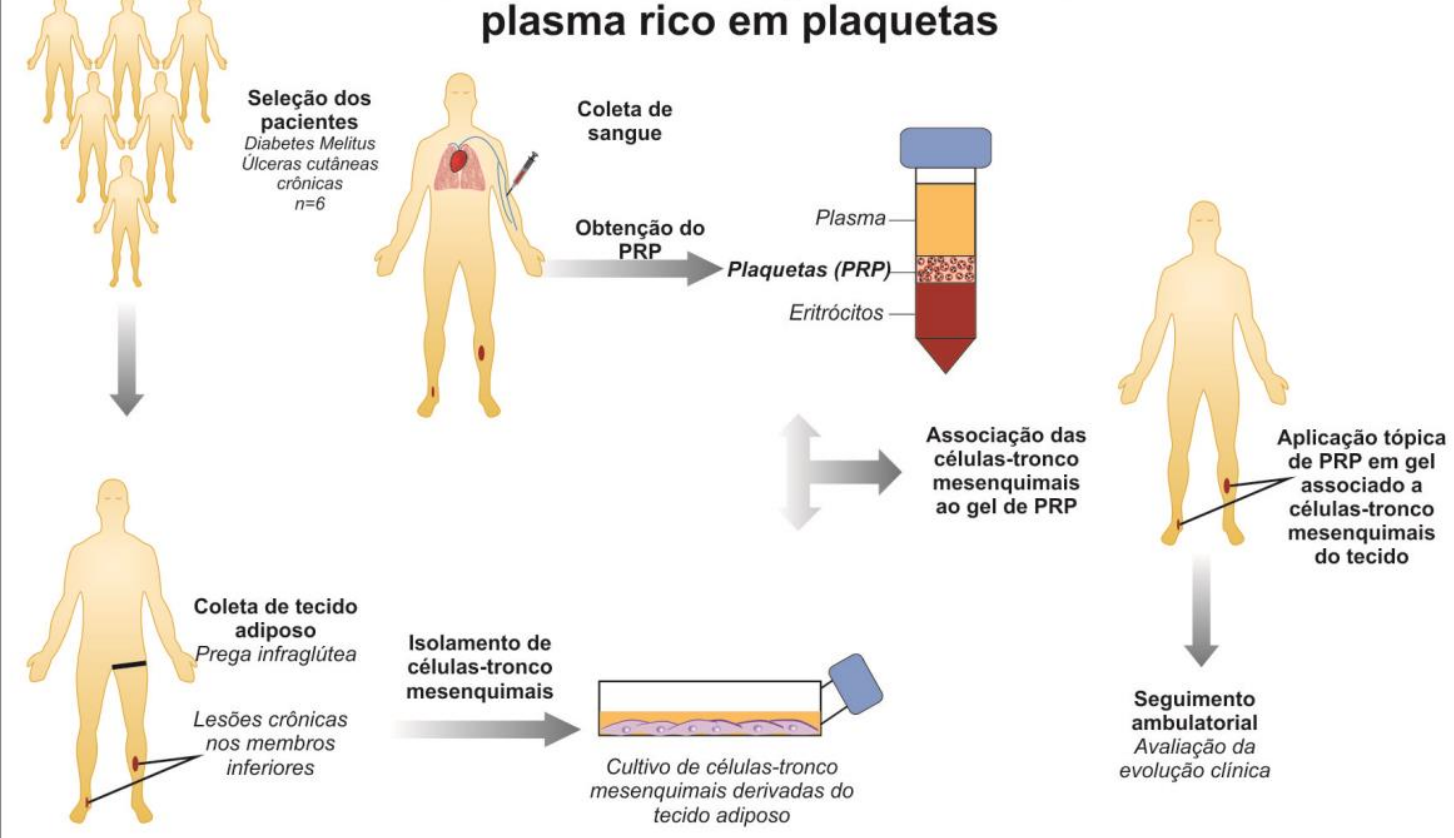

Isolamento de
células-tronco células-tronco
mesenquimais

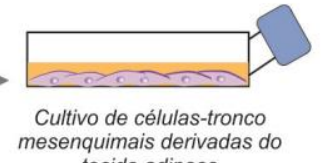

\subsection{Casuística}

A casuística foi composta por seis pacientes portadores de úlceras cutâneas crônicas nos membros inferiores. Todos os pacientes apresentaram diagnóstico de diabetes mellitus (DM) tipo II e lesões tróficas, revascularizadas, porém sem cicatrização significante por um período de, no mínimo, 6 meses. A idade dos pacientes selecionados variou de 55 a 75 anos, sendo a média de 66,33 anos. Quanto ao gênero, foram três pacientes do sexo feminino (F) e três do sexo masculino (M).

Com relação aos fototipos cutâneos, segundo a escala de Fitzpatrick, três pacientes foram caracterizados como fototipos III-IV (morena clara morena moderada) e três pacientes apresentaram fototipos V-VI (morena escura - negra). A Tabela 5 lista as características de cada paciente, bem como os antecedentes mórbidos e o número de lesões. 
Tabela 5 - Distribuição dos pacientes quanto ao gênero, fototipo, antecedentes mórbidos e número de lesões.

\begin{tabular}{lccccc}
\hline Paciente & $\begin{array}{c}\text { Idade } \\
\text { (anos) }\end{array}$ & Sexo & $\begin{array}{c}\text { Fototipo } \\
\text { cutâneo* }\end{array}$ & Antecedentes mórbidos & Úlceras \\
\hline I & 60 & $\mathrm{~F}$ & V-VI & DM, HAS, sobrepeso & 1 \\
II & 60 & M & III-IV & DM, HAS, ex-tabagista há 30 & 1 \\
& & & anos, sobrepeso & \\
III & 75 & F & III-IV & DM, ex-tabagista há 12 anos & 1 \\
IV & 55 & M & VI & DM, HAS & 2 \\
V & 75 & M & V-VI & DM, HAS & 4 \\
VI & 73 & F & III-IV & DM, HAS & 1 \\
\hline
\end{tabular}

${ }^{*}$ Segundo a escala de Fitzpatrick

DM: Diabetes mellitus.

HAS: Hipertensão arterial sistêmica.

Todos os pacientes foram acompanhados durante noventa dias no ambulatório de Feridas da Disciplina de Dermatologia e no ambulatório de Úlceras Venosas da Disciplina de Cirurgia Vascular do Departamento de Cirurgia, ambos os ambulatórios da Faculdade de Ciências Médicas da Universidade Estadual de Campinas - UNICAMP.

Obedecidos os critérios de inclusão e exclusão (itens 3.12 e 3.13), os pacientes portadores de úlceras crônicas, submetidos à abordagens terapêuticas convencionais, tais como curativos, pomadas e hidrogeis, porém sem melhora clínica significante, foram convidados a participar do estudo, mediante ciência, concordância, leitura e assinatura do TCLE (Anexo D).

Os pacientes foram submetidos à coleta de fragmentos de tecido adiposo para isolamento e cultura de CT-TA. Aproximadamente 25 dias após a coleta do tecido adiposo, os pacientes foram submetidos à coleta de sangue para preparo do PRP, em acordo com o protocolo proposto por Jo e colaboradores (2013). Houve, no mesmo dia da coleta de sangue, a administração tópica do PRP associado às CT-TA no leito das úlceras crônicas.

\subsection{Critérios de inclusão dos pacientes}

1. Idade superior a 18 anos.

2. Presença de úlcera cutânea crônica de membro inferior.

3. Diagnóstico de diabetes mellitus.

4. Tratamento clínico ineficaz. 
5. Aceitável condição nutricional.

6. Ausência de cardiopatias.

7. Satisfatório perfil psico-social, emocional e suporte familiar.

8. Comprometimento com o estudo (ausência de auto-medicação e/ou interferência nas úlceras sob tratamento).

9. Concordância com o termo de consentimento livre e esclarecido, Anexo D.

\subsection{Critérios de exclusão dos pacientes}

1. Doenças infectocontagiosas.

2. Doenças imunossupressoras.

3. Problemas psico-sociais, abuso de drogas, álcool e desobedientes ao protocolo médico estabelecido.

4. Não aceitação familiar.

5. Participação em outros estudo clínicos.

\subsection{Coleta de sangue}

Cumprido o tempo de cultivo das células, equivalente ao alcance da terceira passagem ou, aproximadamente, 25 dias após a coleta de tecido adiposo,os pacientes foram convocados para coleta de sangue. A quantidade de sangue coletada foi proporcional ao tamanho da lesão de cada paciente, cerca de 1-2 $\mathrm{mL}$ de sangue para cada $1 \mathrm{~cm}^{2}$ de área ulcerosa. A venóclise foi realizada no antebraço com scalp $21 \mathrm{G}$ acoplado a seringas do tipo $\mathrm{S}$ Monovette (Sarstedt, Nümbrecht, Alemenaha) contendo $1 \mathrm{~mL}$ de citrato de sódio a 3,2\% como anticoagulante para $9 \mathrm{~mL}$ de sangue.

\subsection{Obtenção do PRP}

O sangue contido em cada seringa, descrito no item 3.14, foi transferido para tubos tipo Falcon de $15 \mathrm{~mL}$ ( $10 \mathrm{~mL}$ de sangue anti-coagulado por tubo). As amostras sanguíneas foram centrifugadas, conforme metodologia proposta 
por Jo e colaboradores (2013), descrita no protocolo VI do item 3.2.1, para obtenção do PRP.

\subsection{Coleta, processamento e cultura das CT-TA dos pacientes submetidos à terapia}

Os pacientes foram posicionados em decúbito ventral e, após antissepsia com álcool em gel, foi realizada anestesia com lidocaína a $2 \%$ na região de uma das pregas infraglúteas, cobertas e isoladas por campo estéril. Em cada paciente foi realizada uma incisão de aproximadamente $1,5 \mathrm{~cm}$, dissecada até o tecido subcutâneo, para coleta dos fragmentos de tecido adiposo com o auxílio de pinça anatômica e tesoura íris. Foram coletadas, de cada paciente, cerca de $5 \mathrm{~g}$ de tecido adiposo, que foram imersos em tampão fosfato DPBS, pH 7,4, contendo 1\% de penicilina, estreptomicina e L-glutamina, à temperatura ambiente. A incisão foi suturada interna e externamente com pontos separados com fio monofilamentar de nylon 5.0 e, em seguida, um curativo oclusivo foi realizado na área (ZANELATO et al., 2013). A retirada dos pontos foi realizada após 14 dias. A Figura 9 ilustra etapas do procedimento para coleta de tecido adiposo.

Figura 9 - Coleta do tecido adiposo.

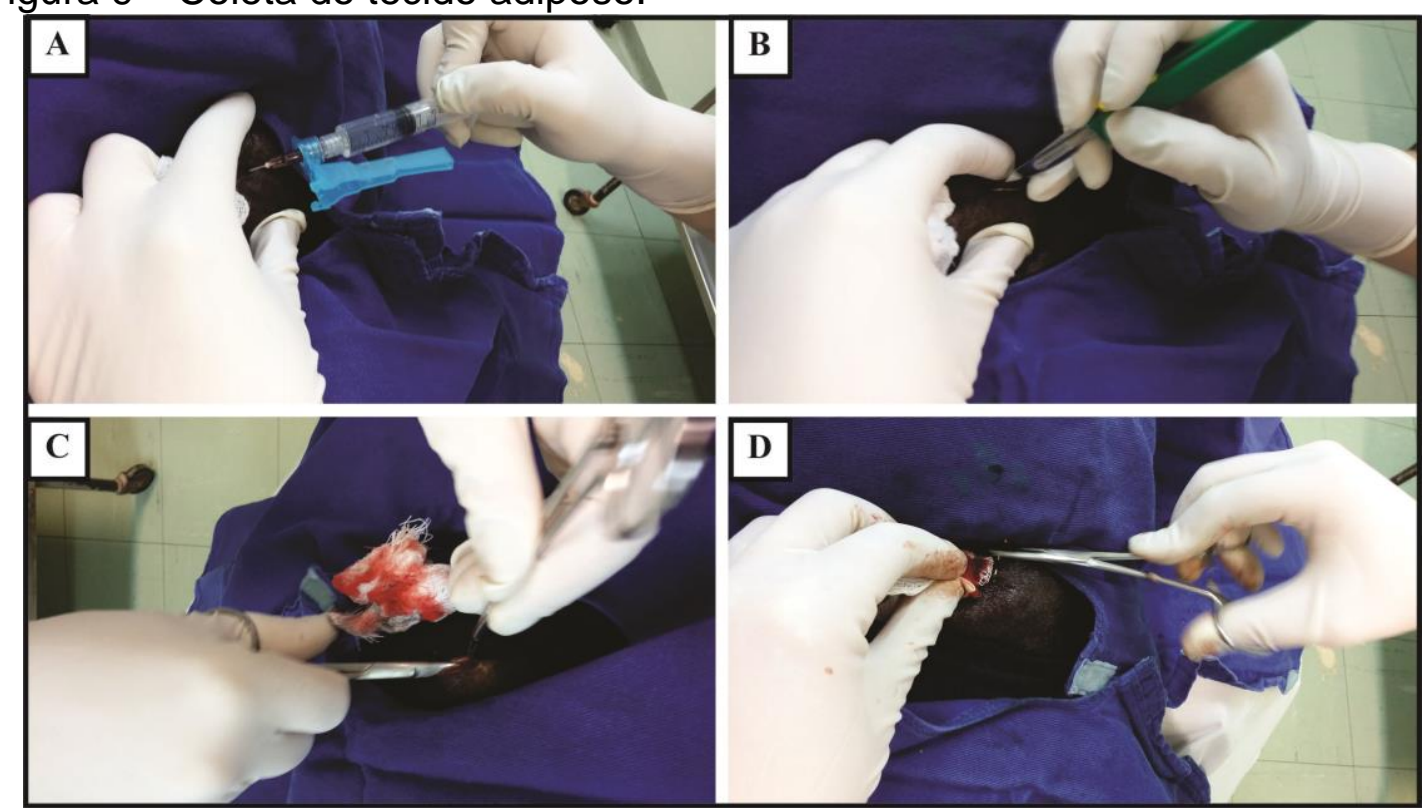

A) Anestesia na região da prega infraglútea. B) Incisão de $1,5 \mathrm{~cm}$ e dissecção até o tecido subcutâneo. C) Exposição do tecido adiposo e punção dos lóbulos de gordura. D) Sutura. 
O procedimento acima descrito foi realizado em salas limpas de consultas do ambulatório de Feridas da Disciplina de Dermatologia da Faculdade de Ciência Médicas da Universidade Estadual de Campinas UNICAMP.

Após a coleta, o tecido adiposo foi transportado ao Laboratório de Cultura de Células da Pele (LCCP) da Faculdade de Ciências Médicas da Universidade Estadual de Campinas - UNICAMP. O referido laboratório possui sala de cultura com sistema de controle ambiental e área limpa Classe ISO 7 (ISO 14644-1) ou Classe 10.000 conforme Federal Standard 209e (BOSNARDO, 2010).

As células coletadas do tecido adiposo foram processadas em acordo com o item 3.4. A contagem de células foi feita em câmara de Neubauer.

\subsection{Controle de qualidade das células}

A averiguação do controle de qualidade foi realizada mediante ensaios de citometria de fluxo, dosagem celular e diferenciação celular, descritos adiante.

1. Citometria de Fluxo e dosagem celular

A citometria de fluxo foi realizada em amostras de CT-TA em terceira passagem, conforme descrito no item 3.4.2. A viabilidade foi realizada por azul de trypan. A dosagem das CT-TA foi obtida por avaliação microscópica, utilizando metodologia padrão de contagem celular por câmara de Neubauer.

2. Potencial de diferenciação das CT-TA in vitro

A verificação do potencial de diferenciação adipogênica, condrôgenica e osteogênica das CT-TA em terceira passagem foi realizada conforme descrito no item 3.4.3.

\subsection{Associação das CT-TA ao PRP}

As CT-TA de cada paciente foram tripsinizadas e centrifugadas a $450 \mathrm{~g}$ por 5 minutos a $20{ }^{\circ} \mathrm{C}$ para remoção do meio de cultura. As células foram lavadas mais duas vezes com tampão fosfato DPBS, pH 7,4. mediante duas 
centrifugações a $450 \mathrm{~g}$ por 5 minutos a $20{ }^{\circ} \mathrm{C}$. A concentração celular foi estimada em câmara de Neubauer, utilizando corante azul de Trypan.

O PRP obtido após a segunda centrifugação, líquido e não ativado, foi utilizado para ressuspender o pellet lavado de CT-TA, sendo aproximadamente utilizados $1 \mathrm{~mL}$ de PRP para cada $5 \mathrm{~cm}^{2}$ de área ulcerosa. Ao PRP associado com as CT-TA foram adicionados 100-200 $\mu \mathrm{L}$ de gluconato de cálcio a $10 \%$ para cada $1 \mathrm{~mL}$ de PRP, com o propósito da ativação do fibrinogênio em fibrina e produção do gel. Rapidamente, após a adição do gluconato de cálcio, a suspensão de CT-TA imersas no PRP ativado foi distribuída sobre a superfície de uma folha de alumínio estéril, com o propósito de facilitar a aplicação e gelificar, como uma membrana ou película, do tamanho e forma das lesões.

Amostras de CT-TA imersas no gel de PRP foram cultivadas in vitro, em meio de cultura M199, suplementado com $10 \%$ de SFB e $1 \%$ de penicilina, estreptomicina e L-glutamina, por 4 dias. Foram feitas imagens com microscópio invertido da interface do gel com o meio de cultura para acompanhar a migração e proliferação das CT-TA nos tempos de 24 e 96 horas. Ainda, imediatamente após a associação das CT-TA ao PRP, amostras do gel foram fixadas em formalina $1 \%$ e cortes histológicos corados com hematoxilina-eosina foram realizados para verificar o aprisionamento das CTTA na matriz de fibrina.

\subsection{Aplicação do gel}

Após obtenção do PRP sob a forma gel e associação das CT-TA cultivadas, fez-se a aplicação tópica, sob técnicas assépticas, em regime ambulatorial, sobre o leito das úlceras. Em casos de lesões localizadas fora da região plantar, o implante foi protegido por um arcabouço plástico (Figura 33.C), com o propósito de evitar o contato direto do curativo com agentes que possam retirar o implante, mantendo a lesão aberta, porém isolada. Nos casos das úlceras localizadas na região plantar foram realizados curativos oclusivos com gaze, embebida no soro liberado naturalmente pela contração do gel.

Após aplicação do implante, os pacientes permaneceram em repouso por 1 hora e, em seguida, foram liberados e orientados para não lavar, tocar ou 
interferir na lesão e no gel aplicado até o primeiro retorno de 7 dias. Após a primeira semana, os pacientes foram orientados para prosseguir com a rotina de curativos e higienização das lesões, apenas com água e sabonete. 


\subsection{Evolução clínica e seguimento dos pacientes}

As úlceras cutâneas foram avaliadas periodicamente, durante 3 meses ou até a completa cicatrização. Os retornos, ou visitas ambulatoriais, para avaliação das úlceras e registro fotográfico, foram distribuídos de forma que no primeiro mês os pacientes compareceram a retornos semanais, no segundo mês os retornos foram quinzenais e, por fim, o último retorno de 3 meses.

A avaliação foi realizada por fotografias obtidas com câmera fotográfica digital, sendo que ao lado e no mesmo plano da lesão foi colocada uma régua. As úlceras foram medidas para avaliação da evolução (BOSNARDO, 2010).

\subsection{Avaliação do índice de cicatrização}

A partir das fotografias realizadas periodicamente, as áreas das úlceras cutâneas foram calculadas mediante software Image $\mathrm{J}$, Na seqüência, foi efetuado cálculo do Índice de Cicatrização das Úlceras (ICU), equivalente ao quociente entre a diferença das Áreas Inicial e Final e a Área Inicial [ICU=(AiAf)/Ai] (BOSNARDO, 2010).

\subsection{Análise estatística}

Os resultados foram referidos como média \pm desvio padrão da média. A normalidade das variâncias foi analisada pelo teste de Shapiro-Wilk. Para verificar as diferenças significantes dos ensaios com mais de dois grupos foi utilizado Análise de Variância (ANOVA) seguida de teste de Kruskal-Wallis e teste de Student Newman-Keuls para dados não paramétricos. A diferença estatística referente à evolução das úlceras foi calculada pelo teste t pareado. A significância estatística foi considerada quando $p<0,05$. Os testes foram realizados utilizando o software BioEstat 5.3.

\subsection{Aspectos éticos}

Este projeto de pesquisa foi aprovado pelo Comitê de Ética em Pesquisa da Faculdade de Ciências Médicas da UNICAMP (Campinas, São Paulo, 
Brasil) e está registrado junto a Plataforma Brasil sob o número CAAE 11214513.6.0000.5404. 


\section{RESULTADOS}

\subsection{Padronização da metodologia para obtenção do PRP}

No intuito de padronizar, inicialmente, um método de centrifugação para obtenção do PRP, foram executados diferentes protocolos, adotando-se uma etapa de centrifugação (I, II e III) e duas etapas de centrifugação (IV, V e VI). Com o aumento da força centrífuga (g) e do tempo, nos diferentes protocolos com uma ou duas centrifugações, observa-se uma diminuição na concentração de hemácias, leucócitos, neutrófilos e plaquetas, conforme apresentado na Tabela 6.

Tabela 6 - Concentrações das frações celulares e plaquetárias em seis protocolos testados para obtenção de PRP $(n=3)$.

\begin{tabular}{|c|c|c|c|c|}
\hline Protocolo & $\begin{array}{c}\text { Hemácias } \\
\left(10^{6} / \mu \mathrm{L}\right)\end{array}$ & $\begin{array}{c}\text { Leucócitos } \\
\left(10^{3} / \mu \mathrm{L}\right)\end{array}$ & Neutrófilos $\left(10^{3} / \mu \mathrm{L}\right)$ & Plaquetas $\left(10^{3} / \mu \mathrm{L}\right)$ \\
\hline ST & 3,620 & 3,960 & 1,940 & 232,000 \\
\hline I & $0,160 \pm 0,141$ & $2,916 \pm 2,544$ & $0,830 \pm 0,759$ & $424,330 \pm 3,510$ \\
\hline II & $0,033 \pm 0,025$ & $0,610 \pm 0,576$ & $0,273 \pm 0,251$ & $302,000 \pm 37,000$ \\
\hline III & $0,010 \pm 0,000$ & $0,070 \pm 0,104$ & $0,026 \pm 0,046$ & $236,000 \pm 9,165$ \\
\hline IV & $0,343 \pm 0,259$ & $3,683 \pm 1,707$ & $1,453 \pm 0,738$ & $911,000 \pm 137,021$ \\
\hline V & $0,043 \pm 0,032$ & $0,416 \pm 0,453$ & $0,190 \pm 0,190$ & $557,333 \pm 21,007$ \\
\hline VI & $0,020 \pm 0,000$ & $0,260 \pm 0,245$ & $0,120 \pm 0,120$ & $476,667 \pm 51,926$ \\
\hline
\end{tabular}

ST: sangue total.

Após a primeira centrifugação, há a separação do plasma, sobrenadante (PS) da fração eritrocítica (rica em hemácias). Quanto maior a força centrífuga $(\mathrm{g})$, maior o volume de plasma $\left(V_{(\mathrm{pl}) \mathrm{PS})}\right.$ obtido, conforme expresso na Tabela 7.

Tabela 7 - Médias ( $n=3$ ) das eficiências de recuperação do plasma e das plaquetas obtidos por diferentes protocolos.

\begin{tabular}{|c|c|c|c|c|c|}
\hline Protocolo & $V_{(p) P S}(m L)$ & $V_{(\mathrm{pl}) \operatorname{PRP}}(\mathrm{mL})$ & $E_{(p) \operatorname{Ps}}(\%)$ & $E_{(\mathrm{pt}) \mathrm{PRP}}(\%)$ & $F_{\mathrm{CP}}$ \\
\hline 1 & $1,538 \pm 0,058$ & $0,506 \pm 0,125$ & $48,31 \pm 1,84$ & $29,10 \pm 6,98$ & $1,823 \pm 0,015$ \\
\hline II & $1,863 \pm 0,143$ & $1,000 \pm 0,000$ & $58,58 \pm 4,51$ & $40,92 \pm 5,01$ & $1,300 \pm 0,160$ \\
\hline III & $2,040 \pm 0,070$ & $1,000 \pm 0,000$ & $64,14 \pm 2,20$ & $31,98 \pm 1,24$ & $1,013 \pm 0,041$ \\
\hline IV & $1,786 \pm 0,090$ & $0,323 \pm 0,025$ & $56,18 \pm 2,85$ & $39,89 \pm 6,51$ & $3,920 \pm 0,591$ \\
\hline V & $2,153 \pm 0,020$ & $0,683 \pm 0,145$ & $67,71 \pm 0,65$ & $51,42 \pm 9,98$ & $2,400 \pm 0,090$ \\
\hline VI & $2,113 \pm 0,085$ & $0,936 \pm 0,086$ & $66,45 \pm 2,67$ & $60,12 \pm 1,77$ & $2.050 \pm 0,226$ \\
\hline
\end{tabular}




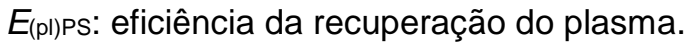

$E_{(\mathrm{pt}) P R P}$ : eficiência da recuperação plaquetária.

$F_{\mathrm{CP}}$ : fator de concentração plaquetária.

Sobre o fator de concentração plaquetária, $F_{\mathrm{CP}}$, observa-se que nos protocolos com uma etapa de centrifugação não há aumento relevante do número de plaquetas, em relação à concentração plaquetária no ST. Ao contrário, nos protocolos com duas etapas de centrifugação, verifica-se um aumento no número de plaquetas, bem como nos demais componentes celulares. Desta forma, foi escolhido e adotado como padrão, neste estudo, o protocolo VI, devido aos mais baixos níveis de leucócitos e neutrófilos (Tabela 6), sendo, pelo menos, o número de plaquetas basais dobrado (Tabela 7).

\subsection{Análise do pH após ativação plaquetária}

Com o propósito de controlar a acidez na formulação do gel de PRP, os valores de $\mathrm{pH}$ foram mensurados após adição de gluconato de cálcio a $10 \%$ em diferentes proporções para formação do gel. Os resultados são expressos na Tabela 8.

Tabela 8 - Valores de pH obtidos após ativação plaquetária com diferentes proporções de gluconato de cálcio a $10 \%$ para cada $1 \mathrm{~mL}$ de PRP.

\begin{tabular}{lc}
\hline PRP ativado com diferentes volumes de gluconato de cálcio a $\mathbf{1 0} \%$ & pH \\
\hline PRP não ativado & 7,1 \\
$25 \mu \mathrm{L}$ & 7,0 \\
$50 \mu \mathrm{L}$ & 6,7 \\
$100 \mu \mathrm{L}$ & 6,5 \\
$200 \mu \mathrm{L}$ & 6,3 \\
$300 \mu \mathrm{L}$ & 6,2 \\
\hline
\end{tabular}

É possível observar que o aumento da concentração de cálcio provoca a redução do $\mathrm{pH}, \circ$ que poderia desencadear incompatibilidade com $0 \mathrm{pH}$ cutâneo e sensação de ardência com o aumento da acidez. Desta forma, não mais que $200 \mu \mathrm{L}$ de gluconato de cálcio a 10\% são compatíveis com a fisiologia normal cutânea. 


\subsection{Ensaio de gelificação}

Em consonância com o método de produção do PRP mais eficiente obtido neste trabalho, protocolo $\mathrm{VI}$, foram preparados 5 ensaios em triplicata, relativos à adição, em diferentes proporções de gluconato de cálcio a 10\%, para ativação plaquetária e formação do gel de PRP. As morfologias dos géis obtidos são mostradas na Figura 10.

Figura 10 - Gelificação do PRP após adição de gluconato de cálcio.

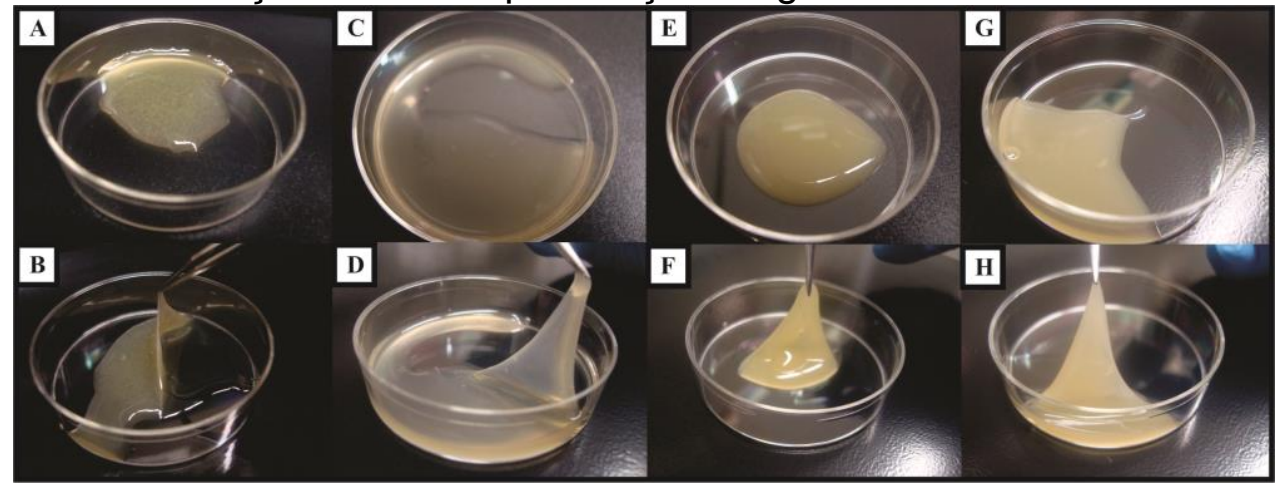

Gelificação do PRP após adição de gluconato de cálcio a 10\%: $50 \mu \mathrm{L}$ (A e B), $100 \mu \mathrm{L}$ (C e D), $200 \mu \mathrm{L}(\mathrm{E}$ e F) e $300 \mu \mathrm{L}(\mathrm{G}$ e H) para cada $1000 \mu \mathrm{L}$ de PRP.

O aumento da quantidade de gluconato de cálcio adicionado ao PRP promove a formação de um gel mais espesso, viscoso e consistente (Figura 10, E-H). Ao contrário, concentrações menores de gluconato de cálcio proporcionam um gel mais fino e delicado, semelhante a um filme (Figura 10. A-D). A menor proporção de gluconato de cálcio adicionado, ou seja, $25 \mu \mathrm{L}$ para cada $1000 \mu \mathrm{L}$ de PRP não resulta na formação de um gel, sendo que o PRP se mantém na forma líquida.

Após ativação plaquetária por adição de gluconato de cálcio, o coágulo, ou gel de PRP, apresenta um processo de contração e liberação dos fatores de crescimento presentes nos a-grânulos em uma fração líquida. Após 1 hora da adição de cálcio, momento em que mais que $95 \%$ dos a-grânulos tem o conteúdo exaurido (MARX, 2004), há maior fração líquida nas formulações com menor quantidade de cálcio adicionado, em acordo com o gráfico apresentado na da Figura 11. 
Figura 11 - Volumes da fração líquida obtida durante contração do gel de PRP ativado em diferentes proporções de gluconato de cálcio a 10\%.

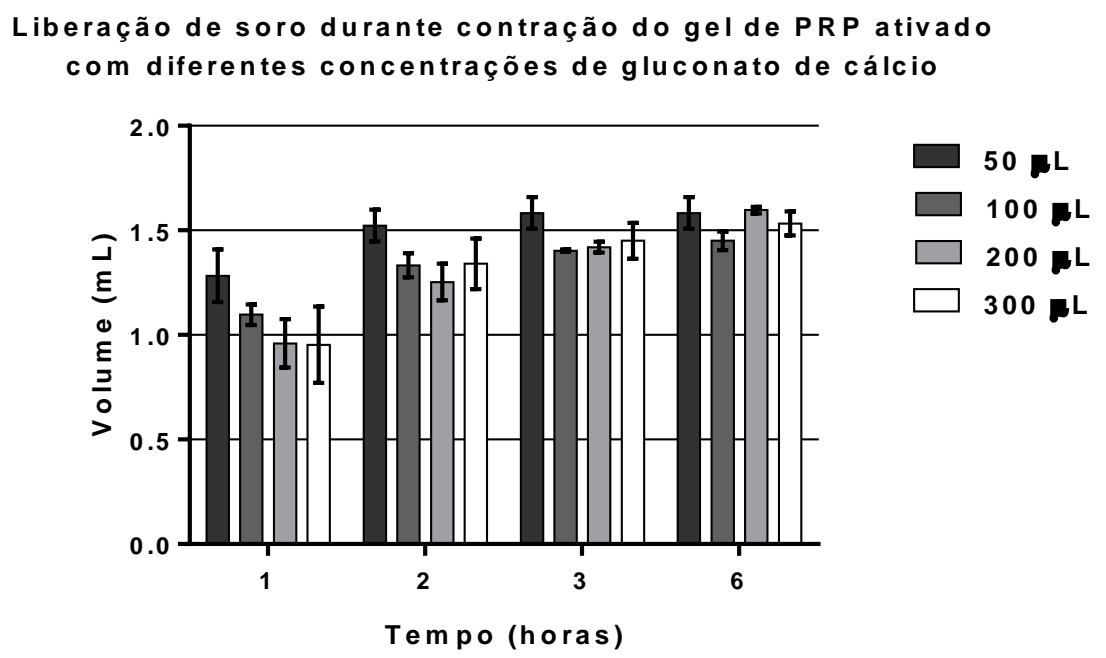

\subsection{Isolamento e expansão das CT-TA}

O isolamento das CT-TA, em acordo com protocolo proposto por Bunnell e colaboradores (2008), permitiu a formação de células aderentes e de aspecto fibroblastoide após dois dias de plaqueamento. Durante a cultura primária, foi observada a presença de debris celulares, provenientes da ação do tampão de lise de hemácias durante $o$ isolamento. Ainda, não foram observados adipócitos maduros no meio de cultura. Deste modo, após 6 dias de cultura primária, foi possível observar uma população de células com aspecto fibroblastoide, com aproximadamente $80-90 \%$ de confluência em relação à área da garrafa de cultura (Figura 12. A).

Figura 12 - Aspecto morfológico de CT-TA verificado por microscopia de contraste de fase.

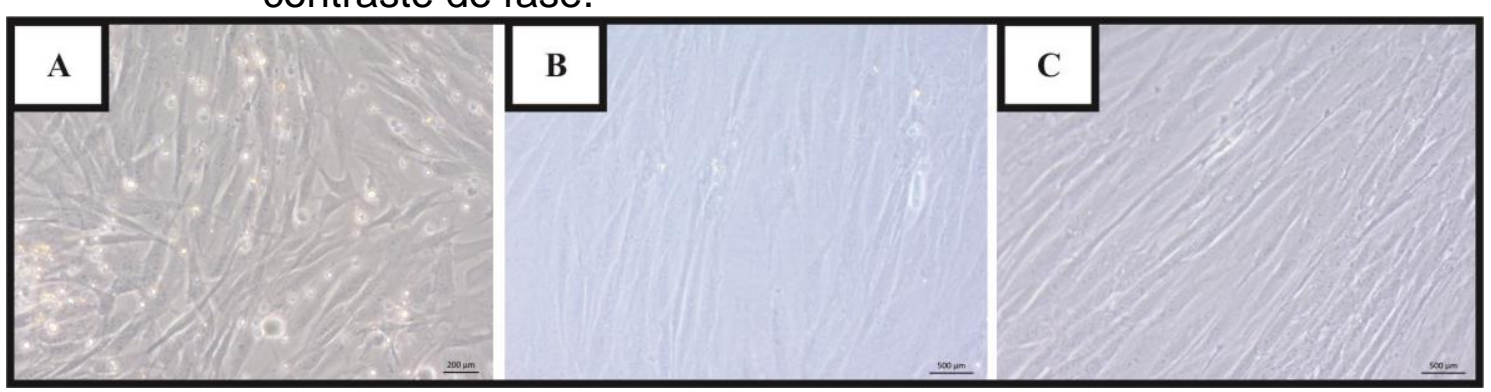

(A) Cultura primária, (B) primeira passagem e (C) segunda passagem. Aumento de 20x. 
Ao longo das passagens e trocas do meio de cultivo, uma população em monocamada homogênea, com morfologia fibroblastoide, tornou-se evidente (Figura 12. B-C). Após a primeira passagem, a expansão ou aumento do número de células tornou-se mais rápido, sendo possível tripsinizações a cada 3-4 dias. As culturas foram mantidas até terceira passagem para realização dos testes de caracterização (imunofenotipagem e diferenciação), ensaios de proliferação e migração.

\subsection{Imunofenotipagem por citometria de fluxo das CT-TA}

O estudo imunofenotípico de CT-TA em terceira passagem revelou expressão mínima $(\leq 2 \%)$ dos marcadores de exclusão, típicos de células progenitoras hematopoiéticas e leucocitárias, como CD34 (0,26\%), CD11b $(0,04 \%)$, HLA-DR $(0,73 \%)$ e CD19 $(0,02 \%)$. Ainda, houve a expressão altamente positiva ( $\geq 95 \%$ ) de marcadores característicos de CTM, como CD73 (99,78\%), CD105 (97,63\%) e CD90 (97,80\%).

A viabilidade da amostra foi de 94,14\%. A Figura 13 apresenta os resultados provenientes da citometria de fluxo na forma gráfica.

Figura 13 -Caracterização imunofenotípica das CT-TA por citometria de fluxo com diferentes marcadores de membrana.

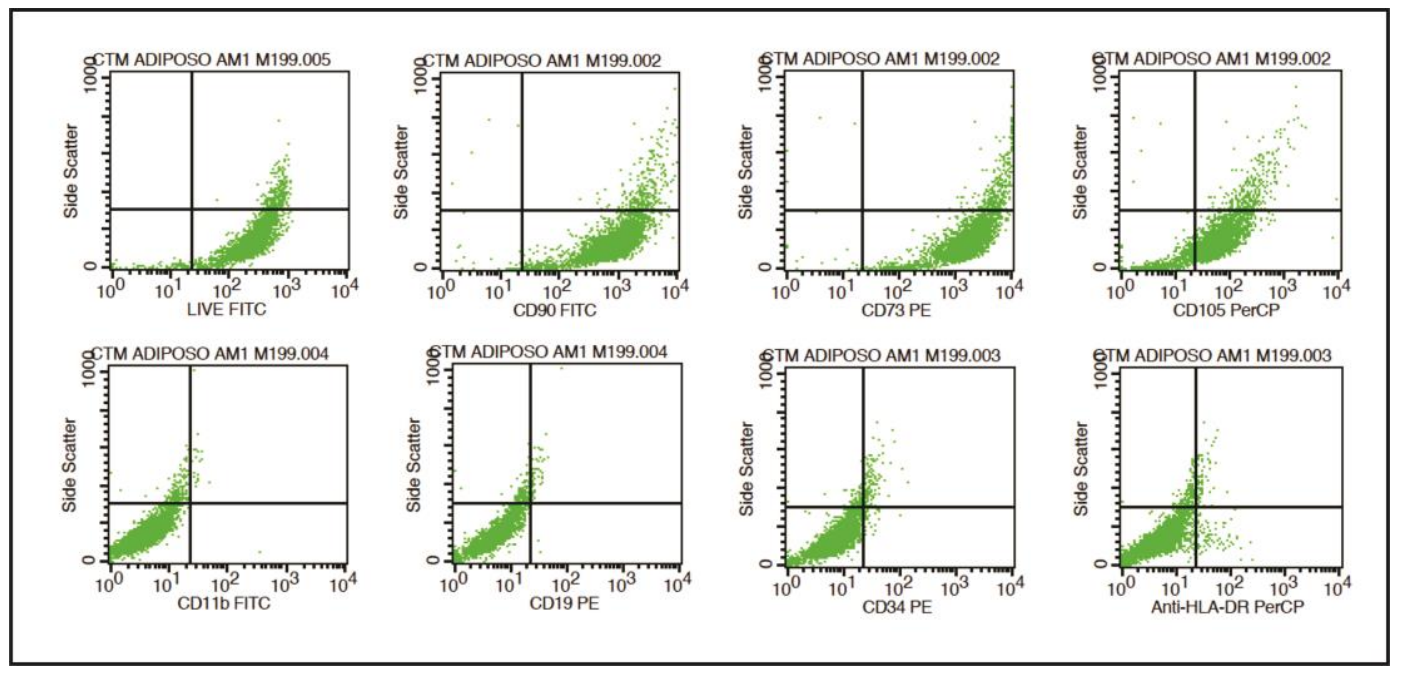

Marcação ( $\geq$ 95\%) para CD90, CD73 e CD105. Marcação ( $\leq 2 \%$ ) para CD11b, CD19, CD34 e HLA-DR.

Os resultados apresentados, provenientes do ensaio por citometria de fluxo, indicam que as CT-TA expandidas in vitro apresentam marcadores de 
superfície característicos de CTM, conforme proposto pela Sociedade Internacional de Terapia Celular (DOMINICl et al., 2006).

\subsection{Potencial de diferenciação das CT-TA}

\subsubsection{Diferenciação adipogênica}

A diferenciação adipogênica das CT-TA foi verificada após 7 dias de cultivo com meio indutor do Kit de Diferenciação Adipogênica StemPro. A diferenciação adipogênica foi comprovada mediante coloração com Oil Red O. A Figura 14 apresenta vacúolos lipídicos citoplasmáticos corados em vermelho característicos de adipócitos maduros.

Figura 14 - Diferenciação adipogênica das CT-TA.

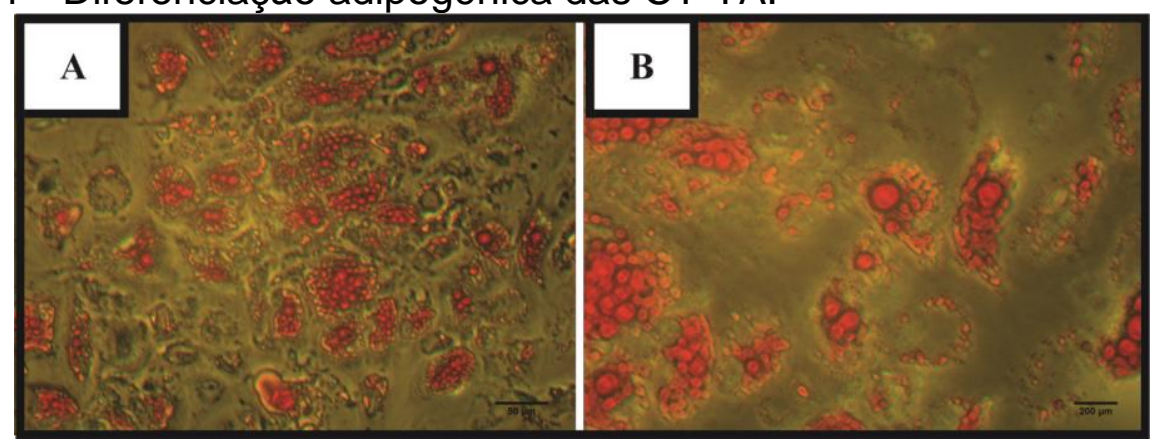

Células diferenciadas em adipócitos, após 7 dias de cultivo e coradas com Oil Red O. A) Aumento de 10x. B) Aumento de 20x.

\subsubsection{Diferenciação condrogênica}

A diferenciação condrogênica das CT-TA foi observada após 14 dias de cultura com meio indutor do Kit de Difereniação Conrogênica StemPro. A validação da diferenciação condrogênica foi verificada por meio de coloração com Alcian Blue. Os proteoglicanos sintetizados pelos condrócitos diferenciados são corados em azul, conforme a Figura 15. 
Figura 15- Diferenciação condrogênica das CT-TA.

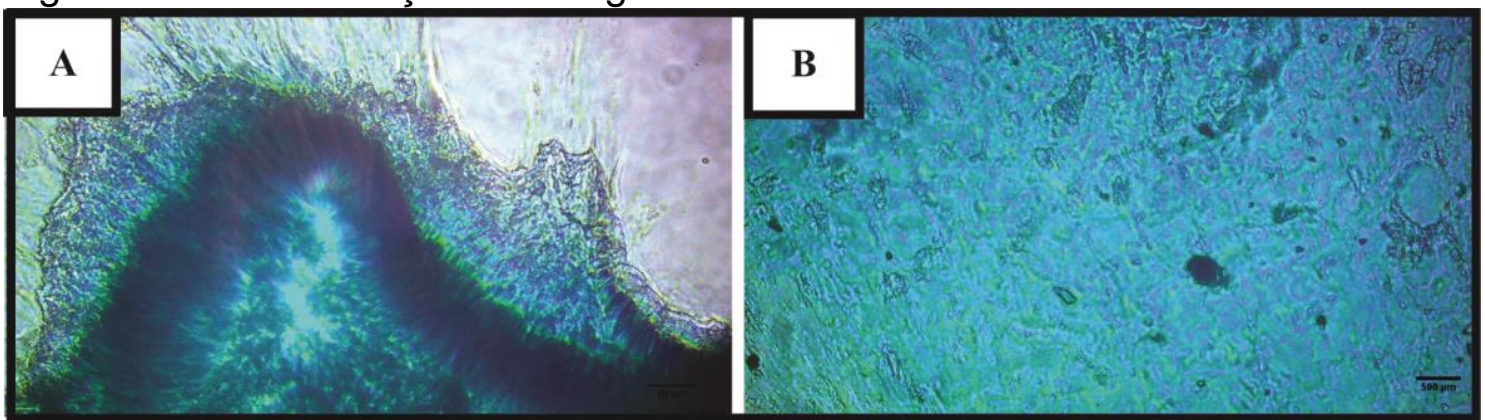

Células diferenciadas em condrócitos, após 14 dias de cultivo e coradas com Alcian Blue. A) Aumento de 10x. B) Aumento de 40x.

\subsubsection{Diferenciação osteogênica}

A diferenciação osteogênica das CT-TA foi observada após 21 dias de cultivo na presença de meio indutor do Kit de Diferenciação Osteogênica StemPro. Os acúmulos de cálcio e a matriz óssea sintetizada pelos osteoblastos podem ser observados em vermelho após coloração com Alizarin Red, conforme a Figura 16.

Figura 16 - Diferenciação osteogênica das CT-TA.

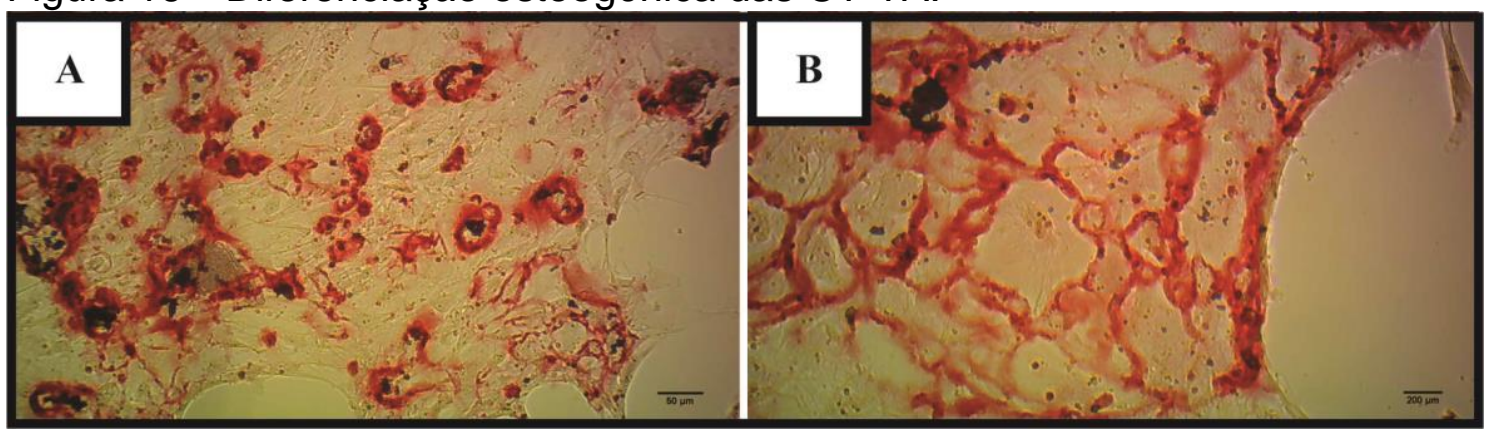

Células diferenciadas em osteoblastos, após 21 dias de cultivo e coradas com Alizarin Red. A) Aumento de 10x. B) Aumento de 20x.

\subsection{Ensaio de proliferação de CT-TA na presença de PRP}

Com o propósito de investigar a influência do PRP sobre o crescimento de CT-TA, foi empregado, via leitura da absorbância a $450 \mathrm{~nm}$ após adição do reagente CCK-8, um ensaio de proliferação de 48 horas. Em acordo com o gráfico da Figura 17, é possível verificar uma relação inversamente proporcional entre a concentração de PRP em cultivo in vitro e a proliferação de CT-TA, qual seja, quanto maior a concentração de PRP, menor a proliferação de CT-TA. 
Figura 17 - Crescimento de CT-TA cultivadas em diferentes concentrações de PRP em comparação com $10 \%$ de SFB e meio de cultura sem suplemento (branco).

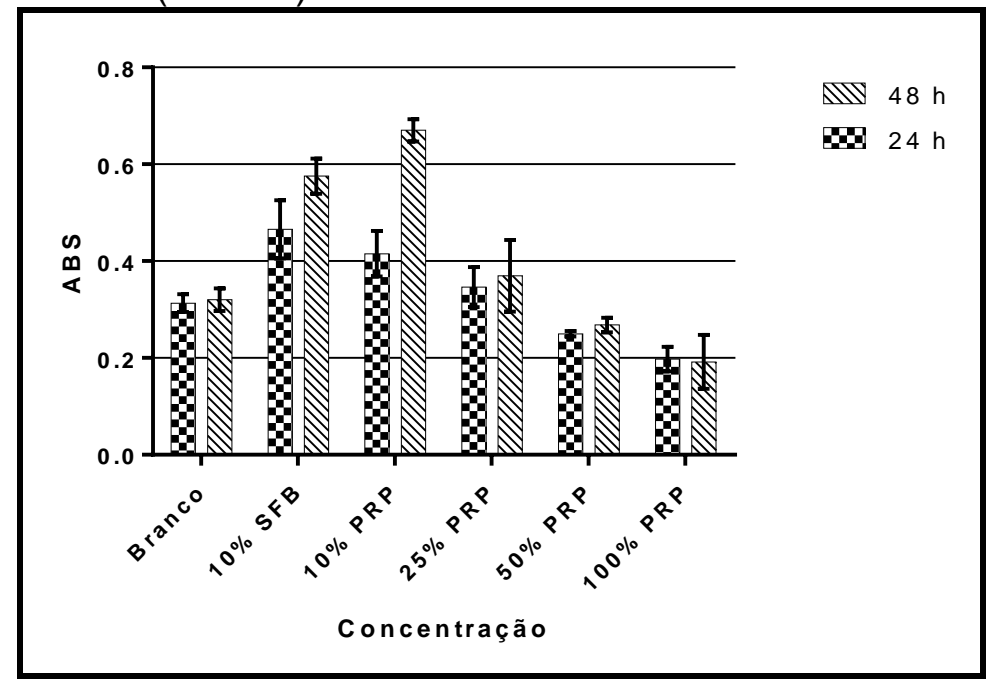

Após 24 horas de cultivo, não houve diferença estatística significante entre os grupos tratados com PRP e o grupo branco, com exceção do grupo cultivado em 100\% de PRP, onde é possível verificar uma redução significante na leitura da absorbância, conforme apresentado na Tabela 9.

Tabela 9 - Médias dos valores de absorbância $(n=6)$ obtidos após 24 e 48 horas para cada grupo de CT-TA cultivadas em diferentes concentrações de PRP.

\begin{tabular}{lcc}
\hline Grupo & $\begin{array}{c}\text { 24 horas } \\
\text { Média } \pm \text { Desvio padrão }\end{array}$ & $\begin{array}{c}\text { 48 horas } \\
\text { Média } \pm \text { Desvio padrão }\end{array}$ \\
\hline Branco & $0,313 \pm 0,018^{\mathrm{bc}}$ & $0,320 \pm 0,023^{\mathrm{bc}}$ \\
$\mathbf{1 0} \%$ SFB & $0,465 \pm 0,059^{\mathrm{a}}$ & $0,575 \pm 0,036^{\mathrm{ab}}$ \\
\hline $\mathbf{1 0} \%$ PRP & $0,415 \pm 0,047^{\mathrm{ab}}$ & $0,670 \pm 0,023^{\mathrm{a}}$ \\
$\mathbf{2 5} \%$ PRP & $0,346 \pm 0,041^{\mathrm{abc}}$ & $0,369 \pm 0,074 \mathrm{bc}$ \\
$\mathbf{5 0} \%$ PRP & $0,250 \pm 0,005^{\mathrm{cd}}$ & $0,268 \pm 0,014 \mathrm{~cd}$ \\
$\mathbf{1 0 0} \%$ PRP & $0,197 \pm 0,025^{\mathrm{d}}$ & $0,192 \pm 0,055^{\mathrm{d}}$ \\
\hline
\end{tabular}

*Médias seguidas de pelo menos uma letra igual indicam diferenças não significantes $(p>0,05)$. Não há relação entre as letras dos tempos 24 e 48 horas.

No intervalo de 48 horas, contudo, há diferença estatística significante entre o grupo branco e o grupo cultivado com 10\% de PRP, sendo a média do grupo com estímulo, duas vezes maior que o grupo branco, conforme apresentado na Tabela 9. Ainda, após 48 horas, a diferença entre o grupo cultivado com $100 \%$ de PRP e o grupo branco é mantida. 


\subsection{Isolamento e proliferação das células da pele}

O aparecimento de células aderentes e de aspecto fibroblastoide foi constatado após dois dias de cultura em meio de cultivo M199. Deste modo, após 10 dias de cultura primária, foi possível observar uma população de células em monocamada com aspecto fibroblastoide, com, aproximadamente, $90-100 \%$ de confluência (Figura 18. A), momento em que foi realizada a primeira passagem.

Figura 18 - Culturas de fibroblastos da derme.

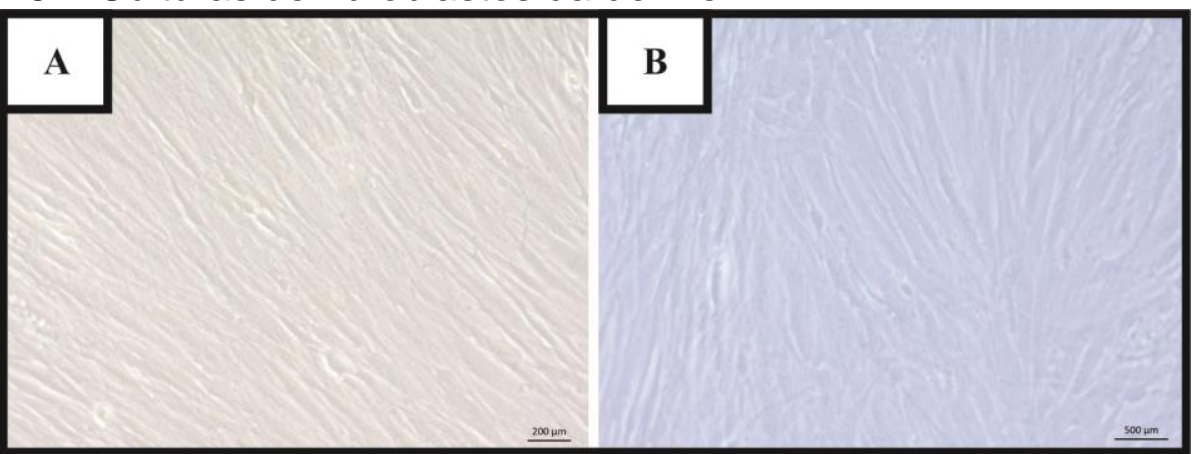

A) cultura primária, B) primeira passagem. Microscopia de contraste de fase. Aumento de 20x.

No decorrer das passagens e trocas do meio de cultivo, a população de fibroblastos em monocamada homogênea, tornou-se evidente (Figura 18. B). Após a primeira passagem, a população celular em cultura apresentou rápida proliferação sendo possíveis tripsinizações a cada 3-4 dias. As culturas foram mantidas até terceira passagem para realização dos testes de proliferação e migração.

A cultura primária de queratinócitos foi estabelecida com a suplementação de $10 \%$ de SFB, sendo este retirado após a primeira passagem. O aparecimento de células aderentes e de aspecto cuboide foi verificado após dois dias do início da cultura em meio de cultivo para queratinócitos. Deste modo, após 14 dias de cultura primária, foi possível observar uma população de colônias celulares com aspecto cuboide e aproximadamente $70-80 \%$ de confluência, momento em que foi realizada a primeira passagem. 
Figura 19 - Culturas de queratinócitos.

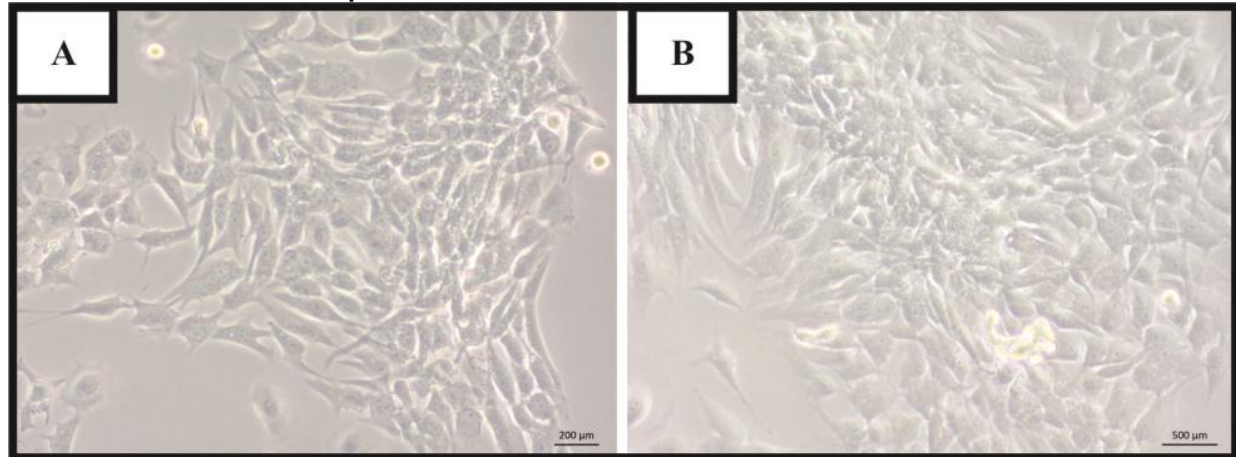

A) primeira passagem, B) segunda passagem. Microscopia de contraste de fase. Aumento de $20 x$.

Ao longo das passagens e trocas do meio de cultivo, a população de queratinócitos, tornou-se evidente (Figura 19. A-B). Após a primeira passagem, a população celular em cultura apresentou proliferação mais expressiva, o que viabilizou tripsinizações a cada 6-7 dias. As culturas foram mantidas até terceira passagem para realização dos testes de proliferação.

\subsection{Ensaio de proliferação das células da pele na presença de PRP e meio condicionado}

Com a finalidade de avaliar a influência do PRP sobre o crescimento de fibroblastos e queratinócitos, foi realizado um ensaio de proliferação de 48 horas, via leitura da absorbância a 450 nm após adição do reagente CCK-8. Em acordo com os gráficos da Figura20, é possível verificar que, semelhante às CTM, quanto maior a concentração de PRP em cultivo in vitro, menor a proliferação de fibroblastos e queratinócitos.

Figura 20 - Crescimento de fibroblastos e queratinócitos cultivados em diferentes concentrações de PRP.

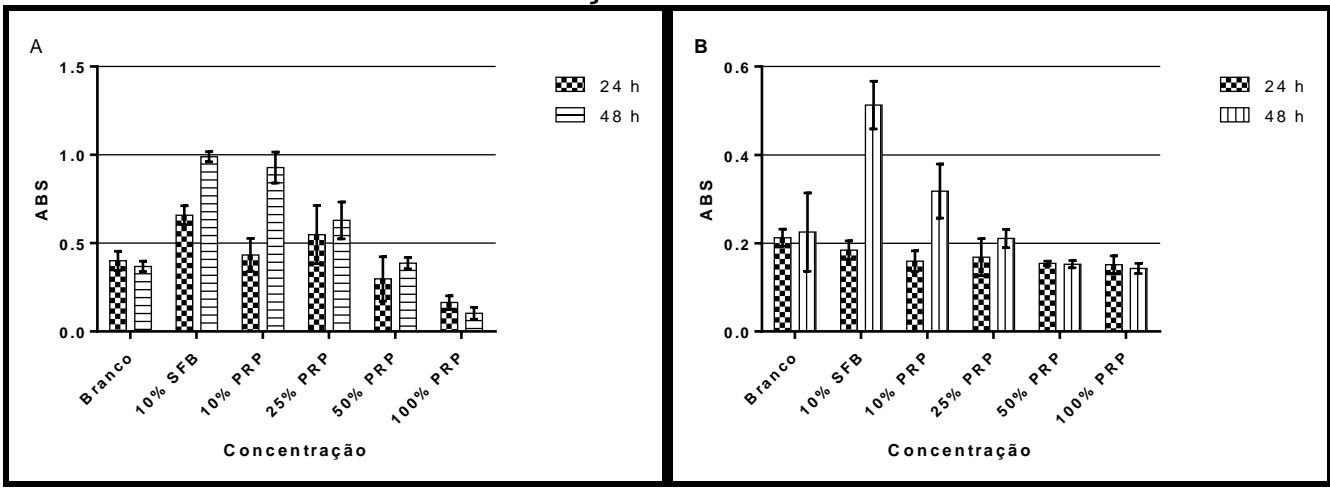

A) fibroblastos e B) queratinócitos cultivados em diferentes concentrações de PRP em comparação com SFB e meio de cultura sem suplemento (branco). 
Após 24 horas de cultivo, não houve diferença estatística significante entre os grupos cultivados com PRP e o grupo branco, com exceção do grupo cultivado em $100 \%$ de PRP, onde é possível verificar uma redução significante na leitura da absorbância, para fibroblastos e queratinócitos, conforme as Tabelas 10 e 11.

Tabela 10 - Médias dos valores de absorbância ( $n=6)$ obtidos após 24 e 48 horas por cada grupo de fibroblastos cultivados em diferentes concentrações de PRP e MC.

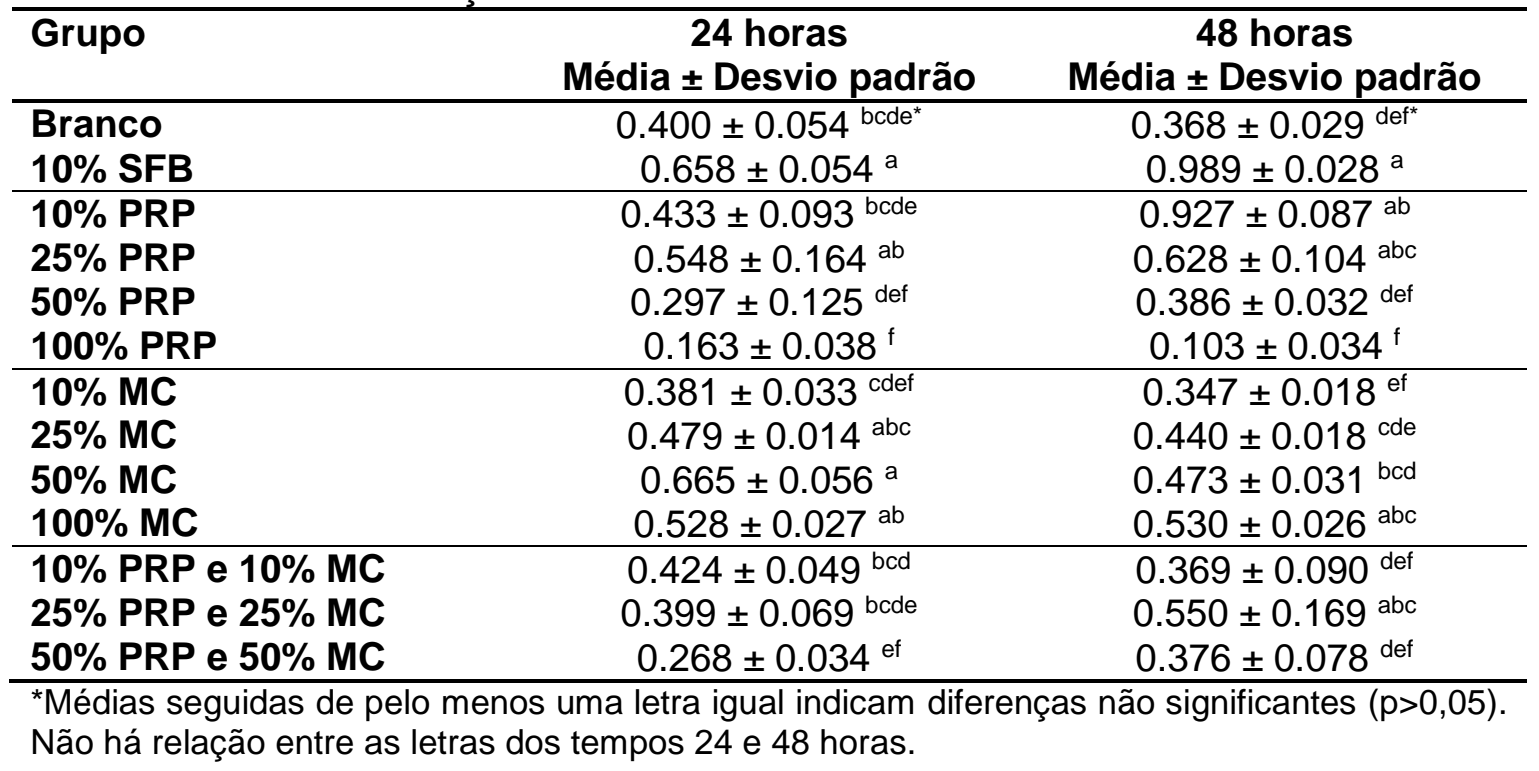

Tabela 11 - Médias dos valores de absorbância ( $n=6)$ obtidos após 24 e 48 horas por cada grupo de queratinócitos cultivados em diferentes concentrações de PRP e MC.

\begin{tabular}{|c|c|c|}
\hline Grupo & $\begin{array}{c}24 \text { horas } \\
\text { Média } \pm \text { Desvio padrão }\end{array}$ & $\begin{array}{c}48 \text { horas } \\
\text { Média } \pm \text { Desvio padrão }\end{array}$ \\
\hline Branco & $0,212 \pm 0,019$ cde $^{*}$ & $0,225 \pm 0,088^{\mathrm{cd}}$ \\
\hline $10 \%$ SFB & $0,184 \pm 0,020$ def & $0,512 \pm 0,053 \mathrm{ab}$ \\
\hline $10 \%$ PRP & $0,159 \pm 0,023$ ef $^{-1}$ & $0,318 \pm 0,061^{b c}$ \\
\hline $25 \%$ PRP & $0,168 \pm 0,041$ def & $0,210 \pm 0,020^{\mathrm{cd}}$ \\
\hline $50 \%$ PRP & $0,154 \pm 0,004$ ef & $0,152 \pm 0,008$ de \\
\hline $100 \%$ PRP & $0,151 \pm 0,019^{f}$ & $0,142 \pm 0,011$ de \\
\hline $10 \% \mathrm{MC}$ & $0,223 \pm 0,027^{\mathrm{bcd}}$ & $0,378 \pm 0,041 \mathrm{abc}$ \\
\hline $25 \%$ MC & $0,269 \pm 0,005 a b c$ & $0,492 \pm 0,049 a b$ \\
\hline $50 \% \mathrm{MC}$ & $0,330 \pm 0,042 a b$ & $0,629 \pm 0,069^{a}$ \\
\hline $100 \% \mathrm{MC}$ & $0,437 \pm 0,044$ & $0,544 \pm 0,025$ ab \\
\hline $10 \%$ PRP e $10 \%$ MC & $0,203 \pm 0,080^{\text {cdef }}$ & $0,103 \pm 0,007^{\mathrm{e}}$ \\
\hline $25 \%$ PRP e $25 \%$ MC & $0,298 \pm 0,057 \mathrm{abc}$ & $0,175 \pm 0,022$ cde \\
\hline $50 \%$ PRP e $50 \%$ MC & $0,205 \pm 0,044$ cdef & $0,220 \pm 0,075^{\mathrm{cd}}$ \\
\hline
\end{tabular}

${ }^{*}$ Médias seguidas de pelo menos uma letra igual indicam diferenças não significantes $(p>0,05)$. Não há relação entre as letras dos tempos 24 e 48 horas. 
Após 48 horas, contudo, há diferença estatística significante entre 0 grupo branco e o grupo de fibroblastos cultivados com 10\% e $25 \%$ de PRP, sendo as médias dos grupos com estímulos, respectivamente, 2,51 e 1,7 vezes superior em comparação com o grupo sem suplemento, conforme a Tabela 10. Ainda, após 48 horas, a diferença entre o grupo cultivado com 100\% de PRP e o grupo branco é mantida nos fibroblastos. Nos grupos de queratinócitos, após 48 horas, não há diferença estatística significante entre os grupos tratados com PRP e sem suplemento.

Com o propósito de investigar a influência do MC, proveniente de CTTA, sobre o crescimento de fibroblastos e queratinócitos, foi empregado, via leitura da absorbância a $450 \mathrm{~nm}$ após adição do reagente CCK-8, um ensaio de proliferação de 48 horas. Em acordo com os gráficos da Figura 21, é possível verificar que quanto maior a concentração de $\mathrm{MC}$ em cultivo in vitro, maior é o estímulo para a proliferação de fibroblastos e, especialmente, de queratinócitos.

Figura 21 - Crescimento de fibroblastos e queratinócitos cultivados em diferentes concentrações de MC derivado de CT-TA.

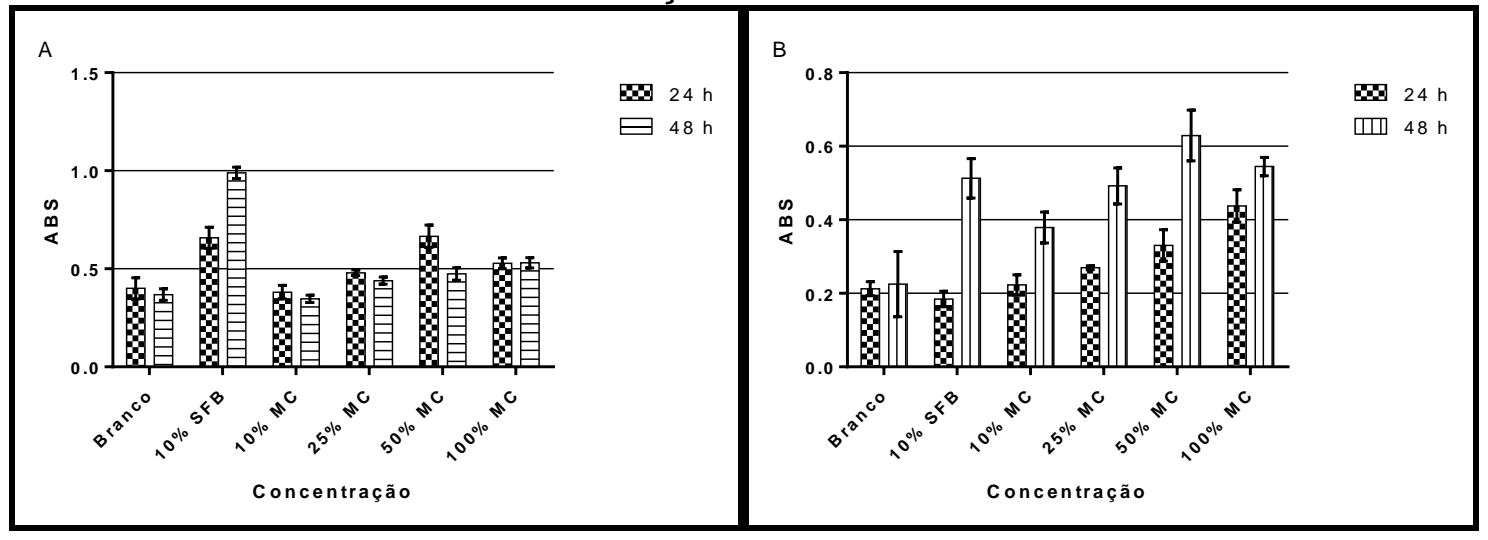

A) fibroblastos e B) queratinócitos cultivados em diferentes concentrações de MC derivado de CT-TA em comparação com SFB e meio sem suplemento (branco).

Após 24 horas de cultivo, houve diferença estatística significante entre 0 grupos de fibroblastos cultivados com $50 \%$ de $\mathrm{MC}$, os grupos de queratinócitos cultivados com $50 \%$ e $100 \%$ de $\mathrm{MC}$ e o grupo branco, com exceção do grupo cultivado em 100\% de PRP, conforme as Tabela 10 e 11.

Com dois dias de cultivo, entre os fibroblastos, houve diferença estatística significante apenas no grupo cultivado com 100\% de MC, ao passo que, entre os queratinócitos, os grupos cultivados com $25 \%$, $50 \%$ e $100 \%$ de 
MC apresentaram diferença estatística significante em comparação com o grupo branco.

Com a proposição final de investigar a ação sinérgica ou aditiva do PRP e MC de CT-TA, foi empregado ensaio de proliferação, mediante leitura da absorbância a $450 \mathrm{~nm}$, após adição do reagente CCK-8. Em acordo com os gráficos da Figura 22, é possível verificar um estímulo para a proliferação de fibroblastos e queratinócitos apenas quando metade do meio de cultivo é suplementado com igual proporção de PRP e MC.

Figura 22 - Crescimento de fibroblastos e queratinócitos cultivados em diferentes concentrações de PRP e MC derivado de CT-TA.

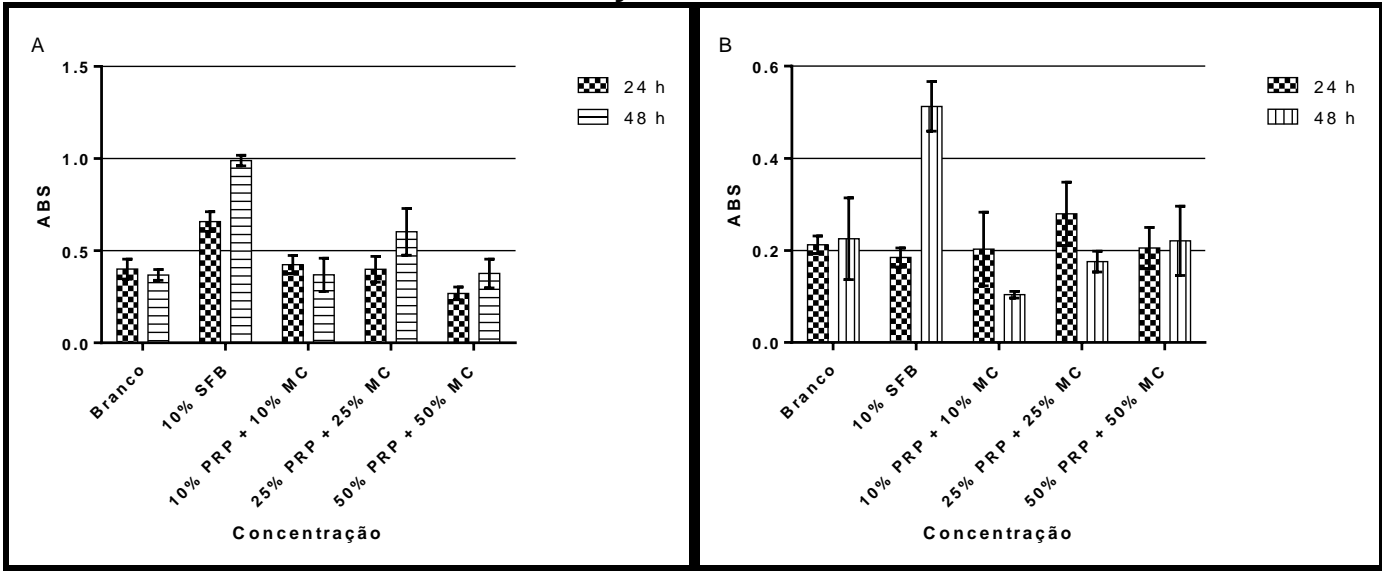

A) fibroblastos e B) queratinócitos cultivados em diferentes concentrações de PRP e MC derivado de CT-TA em comparação com SFB e meio sem suplemento (branco).

O maior estímulo, embora não significante, para a proliferação de queratinócitos é observado após 24 horas de cultivo. Por outro lado, um estímulo significante é observado nos fibroblastos, após 48 horas, cultivados com $25 \%$ de PRP e $25 \%$ de MC.

\subsection{Ensaio de migração}

Para verificar a influência do PRP e MC derivado de CT-TA sobre a capacidade de migração de fibroblastos, foi realizado ensaio de migração (scratch assay). Buscou-se com este ensaio simular, in vitro, um processo de cicatrização natural in vivo, mediante migração celular. O estímulo do PRP sobre o potencial migratório das CTM também foi analisado. Foram capturadas imagens dos traços ou "lesões" feitos sobre a monocamada de células e a 
migração quantificada após 24 e 48 horas, conforme ilustram as Figuras 23 e 24.

Figura 23 - Ensaio de migração de CT-TA.

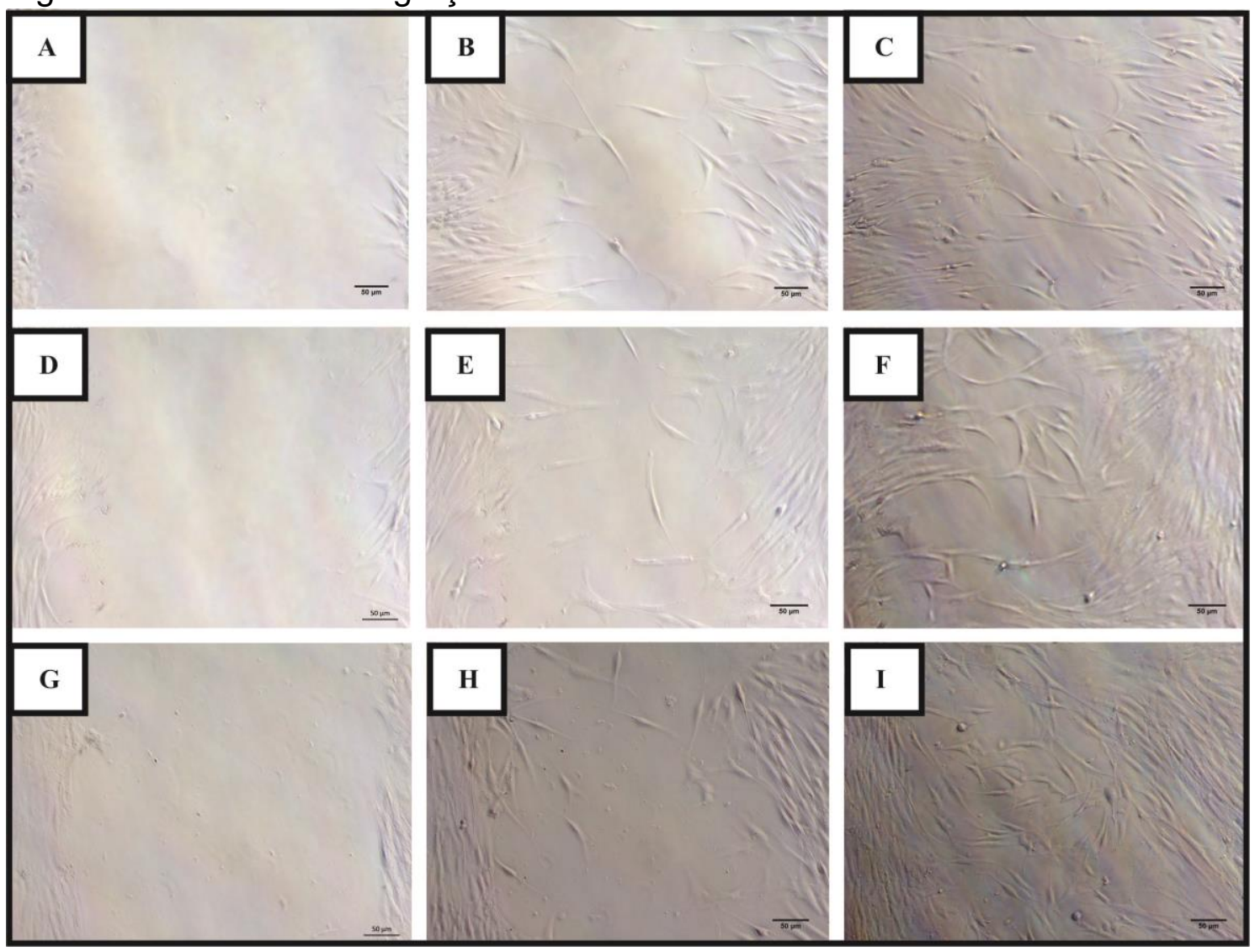

Ensaio de migração de CT-TA cultivadas em meio de cultura sem suplemento (A-C), com 10\% de SFB (D-F) e 10\% de PRP (G-I). Imagens capturadas imediatamente (tempo 0) após 0 desenho do traço $(A, D, G)$, com 24 horas $(B, E, H)$ e 48 horas $(C, F, I)$ após o desenho de um traço sobre a monocamada de CTM.

As CT-TA cultivadas com $10 \%$ de PRP apresentaram diferença estatística significante, medida em porcentagem de área ocupada pelas células, relativa ao estímulo migratório, em comparação com o grupo sem suplemento (branco), após 24 e 48 horas, conforme as Tabelas 12 e 13.

Tabela 12 - Médias $(\mathrm{n}=9)$ das porcentagens relativas às áreas ocupadas por CTM derivadas do tecido adiposo em migração após 24 e 48 horas sob a influência de PRP em comparação com 10\% de SFB e meio de cultura sem suplemento (branco).

\begin{tabular}{lcc}
\hline Grupo & 24 horas & 48 horas \\
& Média \pm Desvio padrão & Média \pm Desvio padrão
\end{tabular}

\begin{tabular}{lll}
\hline Branco & $10.48 \pm 3.63^{\mathrm{a}^{*}}$ & $11.89 \pm 2.68^{\mathrm{a}^{*}}$ \\
$\mathbf{1 0 \%}$ SFB & $16.65 \pm 3.48^{\mathrm{b}}$ & $18.56 \pm 4.46^{\mathrm{b}}$ \\
$\mathbf{1 0 \%}$ PRP & $17.07 \pm 6.47^{\mathrm{b}}$ & $20.02 \pm 2.30^{\mathrm{b}}$ \\
\hline
\end{tabular}

${ }^{*}$ Médias seguidas de pelo menos uma letra igual indicam diferenças não significantes $(p>0,05)$. Não há relação entre as letras dos tempos 24 e 48 horas. 
Figura 24 - Ensaio de migração de fibroblastos da derme cultivados com meio condicionado de CT-TA e PRP.

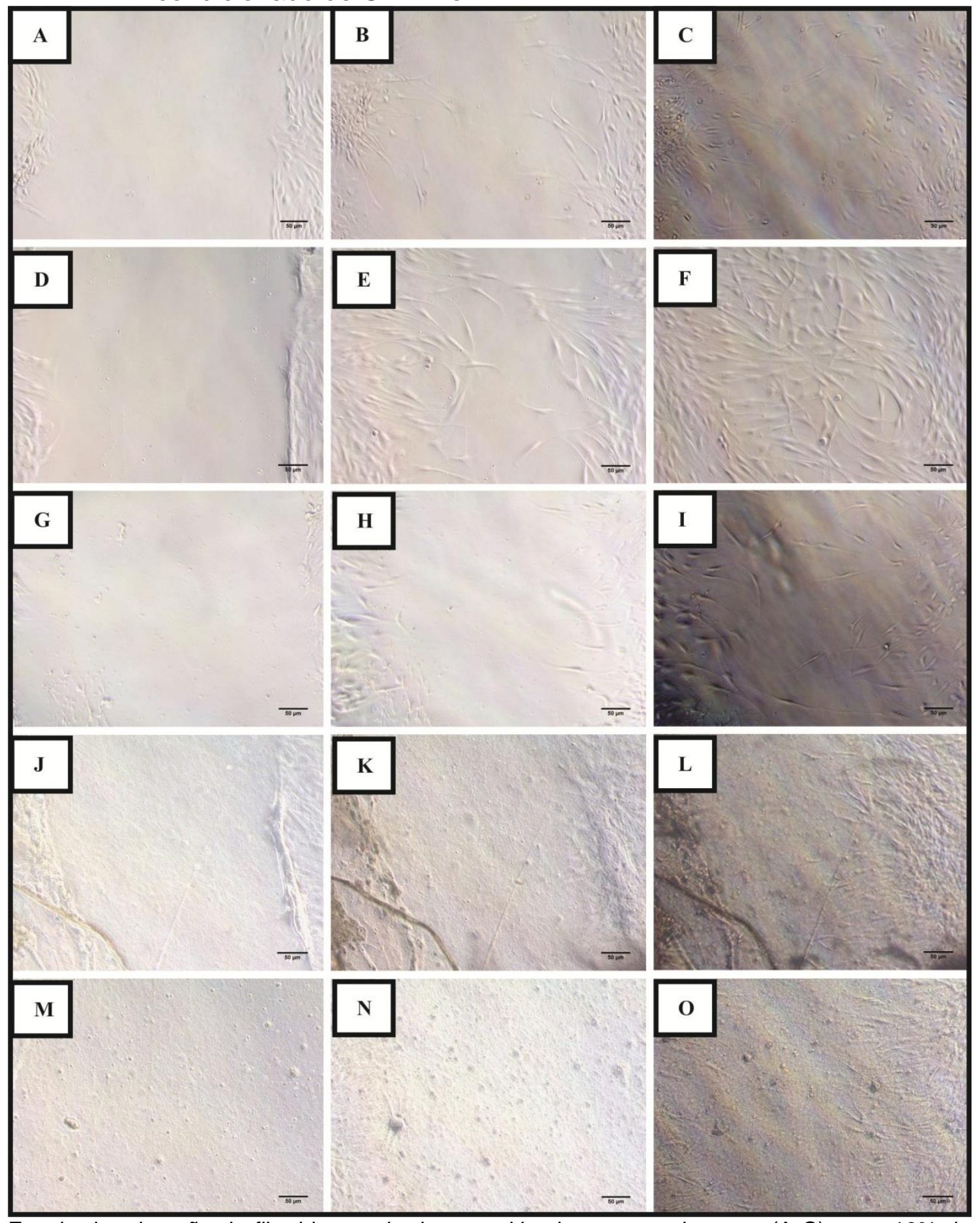

Ensaio de migração de fibroblastos da derme cultivados sem suplemento (A-C), com $10 \%$ de SBF (D-F), 10\% de MC (G-I), 10\% de PRP (J-L) e 10\% de MC + 10\% de PRP (M-O). Imagens capturadas imediatamente (tempo 0) após o desenho do traço (A, D, G, J, M), 24 horas (B, E, $\mathrm{H}, \mathrm{K}, \mathrm{N}$ ) e 48 horas (C, F, I, L, O) após o desenho de um traço sobre a monocamada de fibroblastos. 
A expressão quantitativa do fechamento do scratch, resultante da análise das imagens, por meio do software ImageJ, mostrou diferença estatística significante apenas entre os fibroblastos cultivados com $10 \%$ de PRP $+10 \%$ de MC e o grupo branco, após 48 horas, conforme a Tabela 13.

Tabela 13 - Médias $(n=9)$ das porcentagens relativas às áreas ocupadas por fibroblastos em migração após 24 e 48 horas sob a influência de diferentes concentrações de PRP e MC, em comparação com $10 \%$ de SFB e meio de cultura sem suplemento (branco).

\begin{tabular}{lcc}
\hline Grupo & $\begin{array}{c}\text { 24 horas } \\
\text { Média } \pm \text { Desvio padrão }\end{array}$ & $\begin{array}{c}\text { 48 horas } \\
\text { Média } \pm \text { Desvio padrão }\end{array}$ \\
\hline Branco & $5.67 \pm 1.76 \mathrm{a}^{*}$ & $8.25 \pm 3.04^{\mathrm{a}^{*}}$ \\
$\mathbf{1 0} \%$ SFB & $13.69 \pm 3.65^{\mathrm{b}}$ & $22.02 \pm 4.11^{\mathrm{b}}$ \\
$\mathbf{1 0} \%$ MC & $7.80 \pm 2.98^{\mathrm{a}}$ & $11.05 \pm 5.83^{\mathrm{a}}$ \\
$\mathbf{1 0} \%$ PRP & $5.31 \pm 2.05^{\mathrm{a}}$ & $13.02 \pm 3.22^{\mathrm{a}}$ \\
$\mathbf{1 0} \%$ PRP $+\mathbf{1 0} \%$ MC & $5.83 \pm 1.74^{\mathrm{a}}$ & $17.78 \pm 2.64^{\mathrm{b}}$ \\
\hline${ }^{*}$ Médias seguidas de pelo menos uma letra igual indicam diferenças não significantes $(\mathrm{p}>0,05)$.
\end{tabular}

Não há relação entre as letras dos tempos 24 e 48 horas.

\subsection{Isolamento, cultivo e caracterização das CT-TA para aplicação terapêutica}

O isolamento das CTM derivadas do tecido adiposo, localizado na região da prega infraglútea dos pacientes submetidos à terapia, ocorreu de modo semelhante às CT-TA provenientes da região abdominal e descritas no item 4.4. Embora a quantidade de tecido adiposo destinado a terapia foi pequena, menos que 5 gramas por paciente, foi possível isolar e cultivar células aderentes ao plástico e de aspecto fibroblastoide, conforme ilustra a Figura 25. 
Figura 25 - Aspecto morfológico das CT-TA dos pacientes submetidos à terapia.

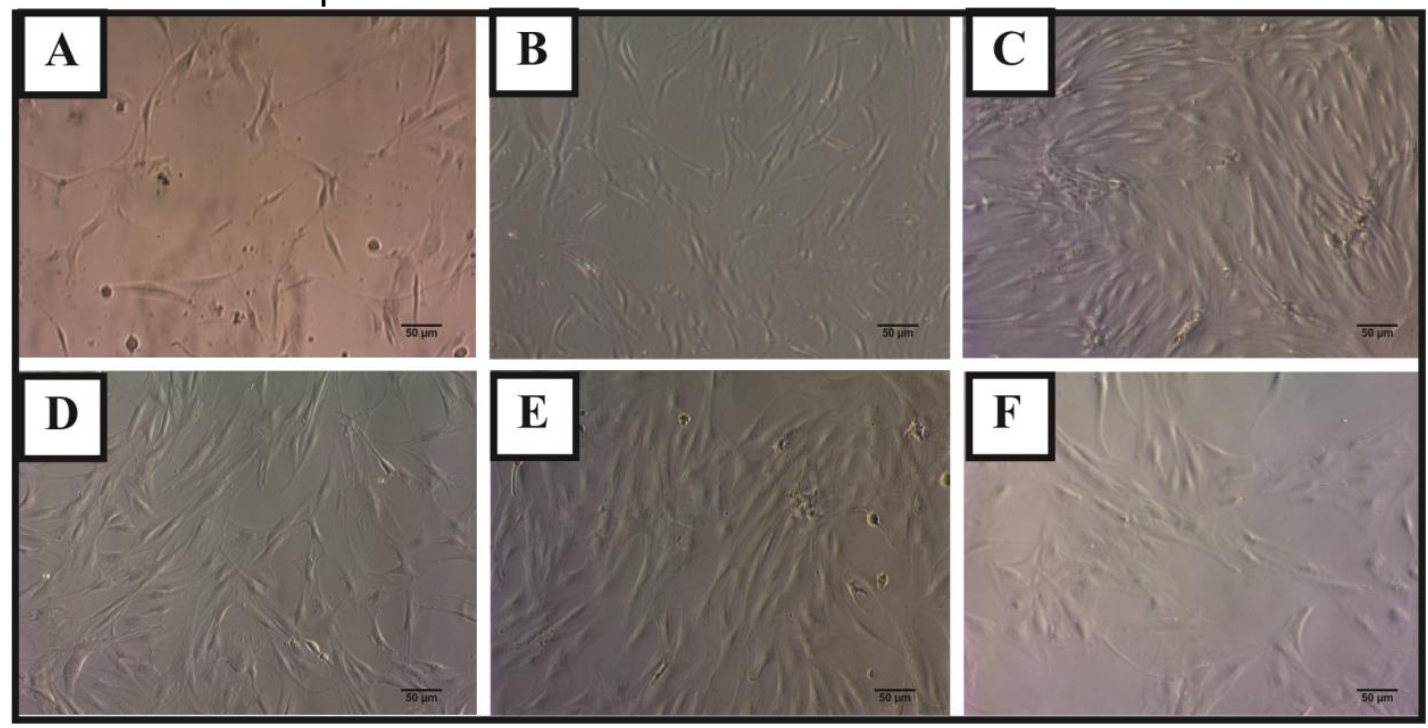

Aspecto morfológico das CT-TA, em diferentes passagens, dos pacientes A) I (cultura primária), B) II (terceira passagem), C) III (primeira passagem), D) IV (segunda passagem), E) $\mathrm{V}$ (segunda passagem) e F) VI (segunda passagem), por microscopia de contraste de fase. Aumento de 10x.

As células dos pacientes submetidos à terapia foram cultivadas até, no máximo, quarta passagem, momento em que os pacientes foram convocados para a aplicação do implante. O tempo de cultura variou de 20 a 30 dias e após a terceira passagem foram recolhidas amostras celulares para a caracterização imunofenotípica por citometria de fluxo e verificação do potencial de diferenciação.

\subsection{Citometria de fluxo das CT-TA para aplicação terapêutica}

No intuito de caracterizar as CT-TA dos pacientes submetidos à terapia, amostras celulares em terceira passagem foram submetidas a imunofenotipagem por citometria de fluxo. A Tabela 14 apresenta, para cada paciente, as porcentagens de cada antígeno de superfície avaliado, bem como a média dos marcadores. 
Tabela 14 - Caracterização imunofenotípica das CT-TA dos pacientes submetidos à terapia.

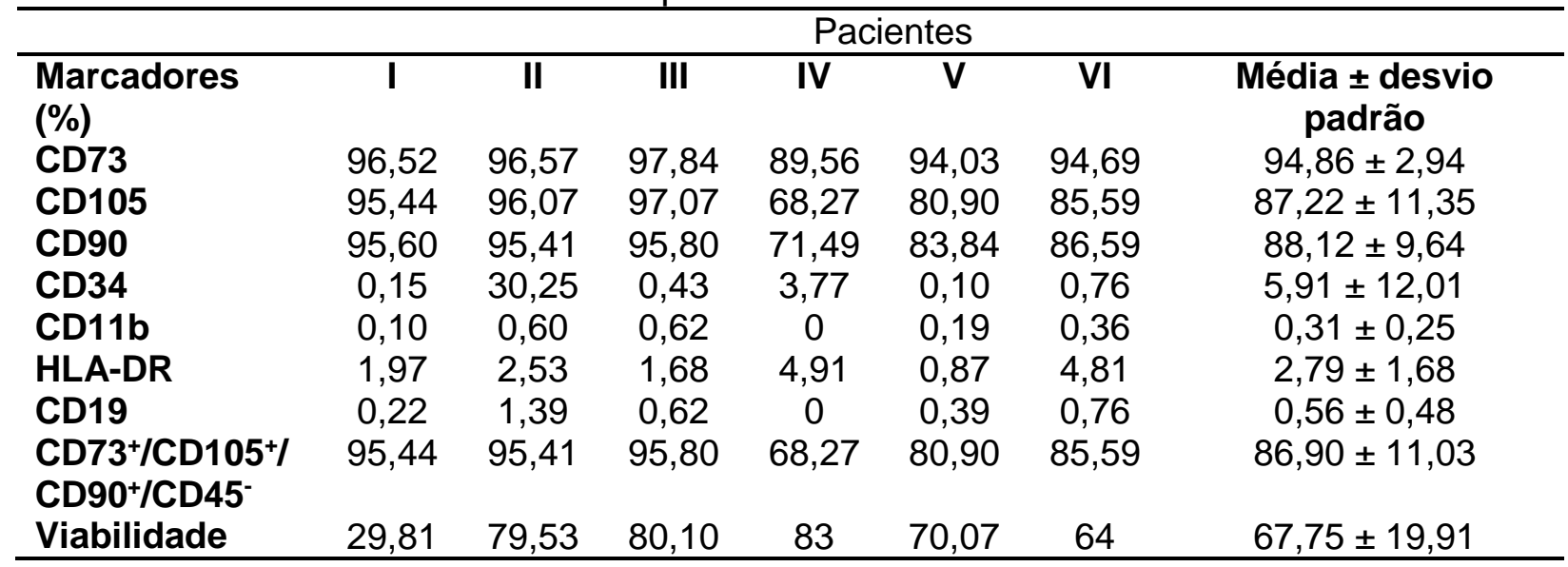

O estudo das subpopulações celulares utilizadas na terapia caracterizou, em média, 86,90\% ( \pm 11,03) como células mesenquimais $\mathrm{CD}_{3}{ }^{+} / \mathrm{CD} 105^{+} / \mathrm{CD} 90^{+} / \mathrm{CD} 45$. Este resultado, aliado as porcentagens individuais obtidas de cada paciente, indicam que foram utilizadas populações de células estromais mesenquimais multipotentes, praticamente homogêneas, sobre as lesões ulcerosas de cada paciente.

\subsection{Diferenciação multipotencial das CT-TA dos pacientes submetidos à terapia}

\subsubsection{Diferenciação adipogênica}

A diferenciação adipogênica das CT-TA dos pacientes submetidos à terapia foi verificada após 7 dias de cultivo com meio indutor do Kit de Diferenciação Adipogênica StemPro. A diferenciação adipogênica foi comprovada mediante coloração com Oil Red O. A Figura 26 apresenta vacúolos lipídicos citoplasmáticos corados em vermelho característicos de adipócitos maduros de todos os pacientes. 
Figura 26 - Diferenciação adipogênica das CT-TA dos pacientes submetidos à terapia.
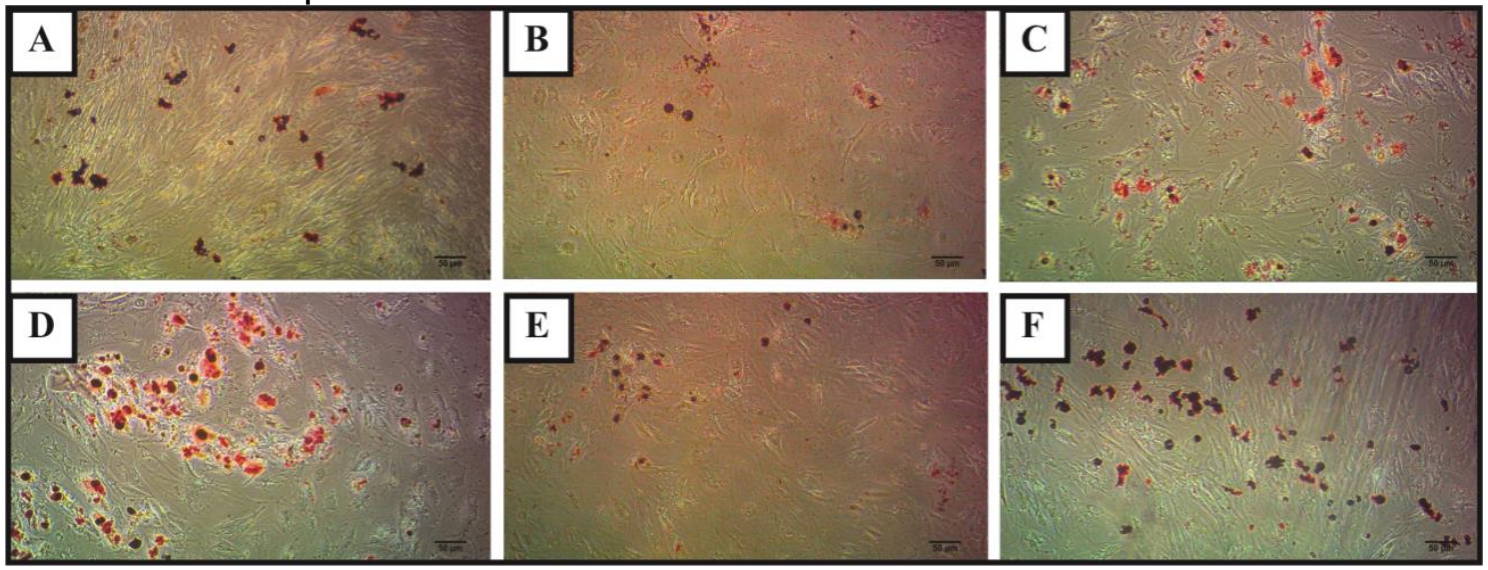

Diferenciações adipogênicas das CT-TA dos pacientes A) I, B) II, C) III, D) IV, E) V e F) VI. Células diferenciadas em adipócitos, após 7 dias de cultivo, e coradas com Oil Red $\mathrm{O}$. Aumento de 10x.

\subsubsection{Diferenciação condrogênica}

A diferenciação condrogênica das CT-TA de cada paciente submetido à terapia foi observada após 14 dias de cultura com meio indutor do Kit de Difereniação Condrogênica StemPro. A validação da diferenciação condrogênica foi verificada pela coloração com Alcian Blue. Os proteoglicanos sintetizados pelos condrócitos diferenciados são corados em azul, conforme a Figura 27.

Figura 27 - Diferenciação condrogênica das CT-TA dos pacientes submetidos à terapia.
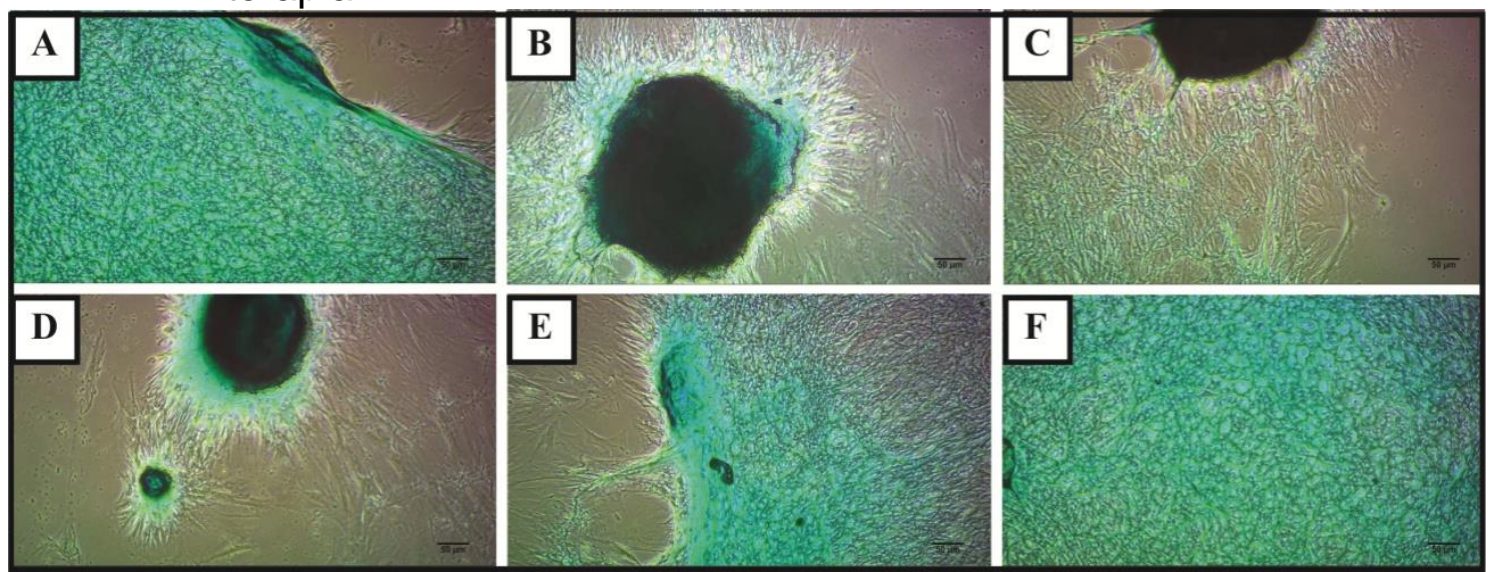

Diferenciação condrogênica das CT-TA dos pacientes A) I, B) II, C) III, D) IV, E) V e F) VI. Células diferenciadas em condrócitos, após 14 dias de cultivo, e coradas com Alcian Blue. Aumento de 10x. 
A diferenciação osteogênica das CT-TA de cada paciente submetido à terapia foi observada após 21 dias de cultivo na presença de meio indutor do Kit de Diferenciação Osteogênica StemPro. Os acúmulos de cálcio e a matriz óssea sintetizada pelos osteoblastos podem ser observados em vermelho após coloração com Alizarin Red, conforme a Figura 28.

Figura 28 - Diferenciação osteogênica das CT-TA dos pacientes submetidos à terapia.
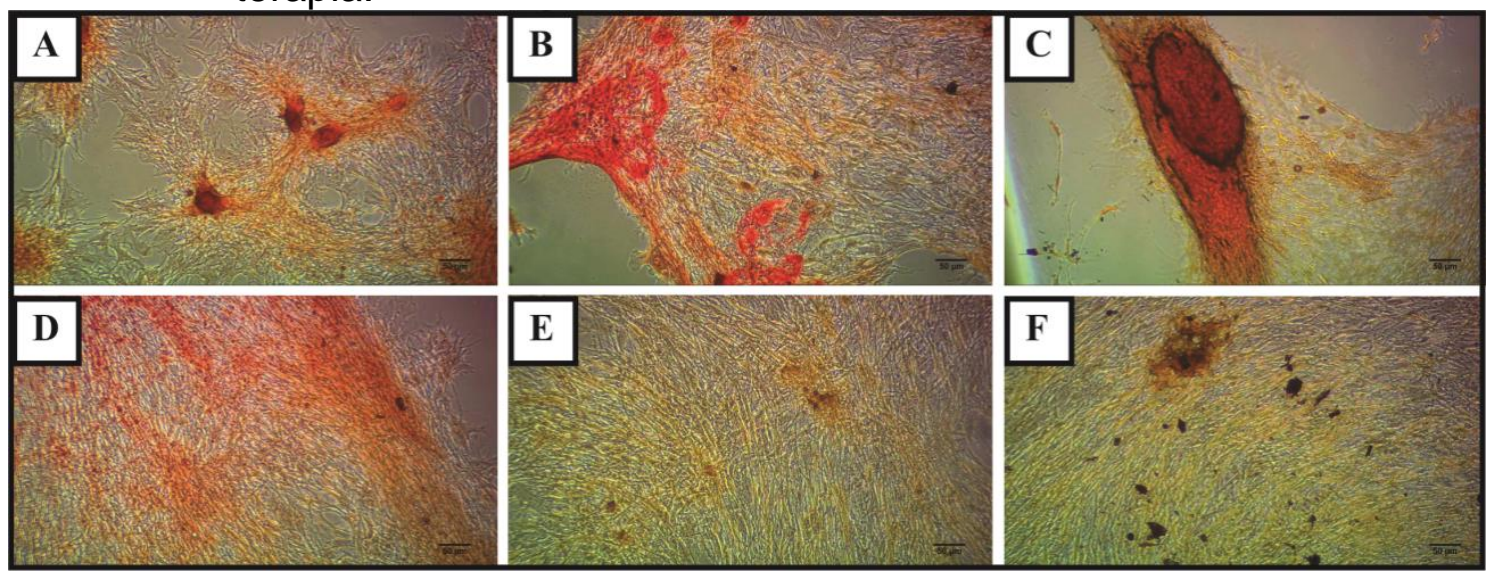

Diferenciação osteogênica das CT-TA dos pacientes A) I, B) II, C) III, D) IV, E) V e F) VI. Células diferenciadas em osteoblastos, após 21 dias de cultivo, e coradas com Alizarin Red. Aumento de 10x.

\subsection{Caracterização do PRP utilizado na terapia}

No dia da aplicação do implante, os pacientes foram convocados para a coleta de sangue, sendo o volume coletado proporcional ao tamanho da lesão de cada paciente, entre 20 e $50 \mathrm{~mL}$ por aplicação. Uma vez obtido o PRP, antes da ativação plaquetária, foram colhidas amostras para quantificação celular, sendo os resultados do hemograma de cada paciente apresentados na Tabela 15, em comparação com os números basais verificados no sangue total. 
Tabela 15 - Concentrações das frações celulares e plaquetárias no sangue total e no PRP de cada paciente.

\begin{tabular}{|c|c|c|c|c|c|c|}
\hline Paciente & $\begin{array}{l}\text { Plaquetas } \\
\text { st }\left(10^{3} / \mu \mathrm{L}\right)\end{array}$ & $\begin{array}{l}\text { Plaquetas } \\
\text { PRP }\left(10^{3} / \mu L\right)\end{array}$ & $\begin{array}{l}\text { Leucócitos } \\
\text { sт }\left(10^{3} / \mu \mathrm{L}\right)\end{array}$ & $\begin{array}{l}\text { Leucócitos } \\
\text { PRP }\left(10^{3} / \mu L\right)\end{array}$ & $\begin{array}{l}\text { Hemácias } \\
\text { st }\left(10^{6} / \mu \mathrm{L}\right)\end{array}$ & $\begin{array}{l}\text { Hemácias } \\
\text { PRP }\left(10^{6} / \mu \mathrm{L}\right)\end{array}$ \\
\hline I & 270 & 592 & 5,86 & 0,47 & 3,74 & 0,05 \\
\hline II & 264 & 490 & 6,98 & 1,69 & 4,27 & 0,06 \\
\hline III & 214 & 380 & 9,77 & 1,11 & 3,92 & 0,02 \\
\hline IV & 306 & 540 & 5,55 & 0,81 & 4,46 & 0,03 \\
\hline$V\left(1^{a} A p\right)$ & 222 & 364 & 7,12 & 0,86 & 4,12 & 0,04 \\
\hline$V\left(2^{a} A p\right)$ & 227 & 631 & 7,10 & 3,07 & 3,40 & 0,10 \\
\hline $\mathrm{VI}\left(1^{a} A p\right)$ & 305 & 560 & 9,15 & 0,15 & 3,19 & 0,03 \\
\hline $\operatorname{VI}\left(2^{a} A p\right)$ & 295 & 520 & 7,85 & 0,40 & 3,27 & 0,05 \\
\hline $\operatorname{VI}\left(3^{a} A p\right)$ & 310 & 669 & 9,51 & 1,62 & 3,27 & 0,06 \\
\hline
\end{tabular}

ST: sangue total.

PRP: plasma rico em plaquetas.

Os resultados da Tabela 15 mostram a redução de leucócitos e hemácias no PRP, em conformidade com o protocolo padronizado para este estudo e proposto por Jo e colaboradores (2013). Ainda, verifica-se o aumento no número de plaquetas, sendo o fator de concentração plaquetário médio equivalente a 2,43 ( \pm 1,69). A Tabela 16 apresenta as eficiências de recuperação de plasma e plaquetas obtidos com o processamento do sangue total de cada paciente.

Tabela 16 - Eficiências na recuperação de plasma e plaquetas obtidos com o processamento do sangue total para produção do PRP de cada paciente.

\begin{tabular}{|c|c|c|c|c|c|c|}
\hline Paciente & $\begin{array}{l}E_{(\mathrm{pl}) \mathrm{PS}} \\
(\%)\end{array}$ & $\begin{array}{l}V_{(\mathrm{p}) \mathrm{ST}} \\
(\mathrm{mL})\end{array}$ & $\begin{array}{c}V_{\mathrm{ST}} \\
(\mathrm{mL}) \\
\end{array}$ & $\begin{array}{l}V_{\text {PRP }} \\
(\mathrm{mL}) \\
\end{array}$ & $\begin{array}{c}E_{(\text {(pt)PRP }} \\
(\%)\end{array}$ & $F_{\mathrm{CP}}$ \\
\hline$T$ & 95,84 & 12,52 & 20 & 4 & 70,05 & 2,192 \\
\hline II & 95,98 & 28,65 & 50 & 10 & 64,78 & 1,856 \\
\hline III & 98,68 & 12,16 & 20 & 4 & 58,41 & 1,775 \\
\hline IV & 50,25 & 11,08 & 20 & 4 & 63,70 & 1,764 \\
\hline$V\left(1^{\mathrm{a}} A p\right)$ & 90,70 & 26,46 & 45 & 9 & 55,77 & 1,639 \\
\hline$V\left(2^{a} A p\right)$ & 90,90 & 26.4 & 40 & 5 & 52,64 & 6,94 \\
\hline $\mathrm{VI}\left(1^{\mathrm{a}} \mathrm{Ap}\right)$ & 88,10 & 27,24 & 40 & 8 & 53,92 & 1,836 \\
\hline $\operatorname{VI}\left(2^{a} A p\right)$ & 89,15 & 26,92 & 40 & 8 & 52,38 & 1,762 \\
\hline $\operatorname{VI}\left(3^{a} A p\right)$ & 89,15 & 33,65 & 50 & 9 & 57,71 & 2,158 \\
\hline
\end{tabular}

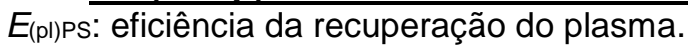

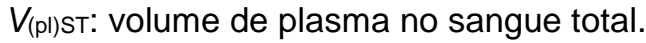

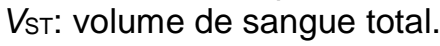

VPRP: volume de plasma rico em plaquetas.

$E_{(\mathrm{pt}) \text { PRP: }}$ eficiência da recuperação plaquetária.

$F_{\mathrm{CP}}$ : fator de concentração plaquetária.

As eficiências médias de recuperação do plasma e plaquetas foram, respectivamente, $87,63 \pm 14,49$ e $58,81 \pm 6,12$. 


\subsection{Verificação da associação das CT-TA ao gel de PRP}

Uma vez associadas ao gel de PRP, as CT-TA são imersas e aprisionadas pela rede de fibrina, formada após ativação plaquetária, em acordo com a Figura 29, onde é possível observar os núcleos das células imersas na matriz de fibrina.

Figura 29 - CT-TA imersas no gel de PRP.

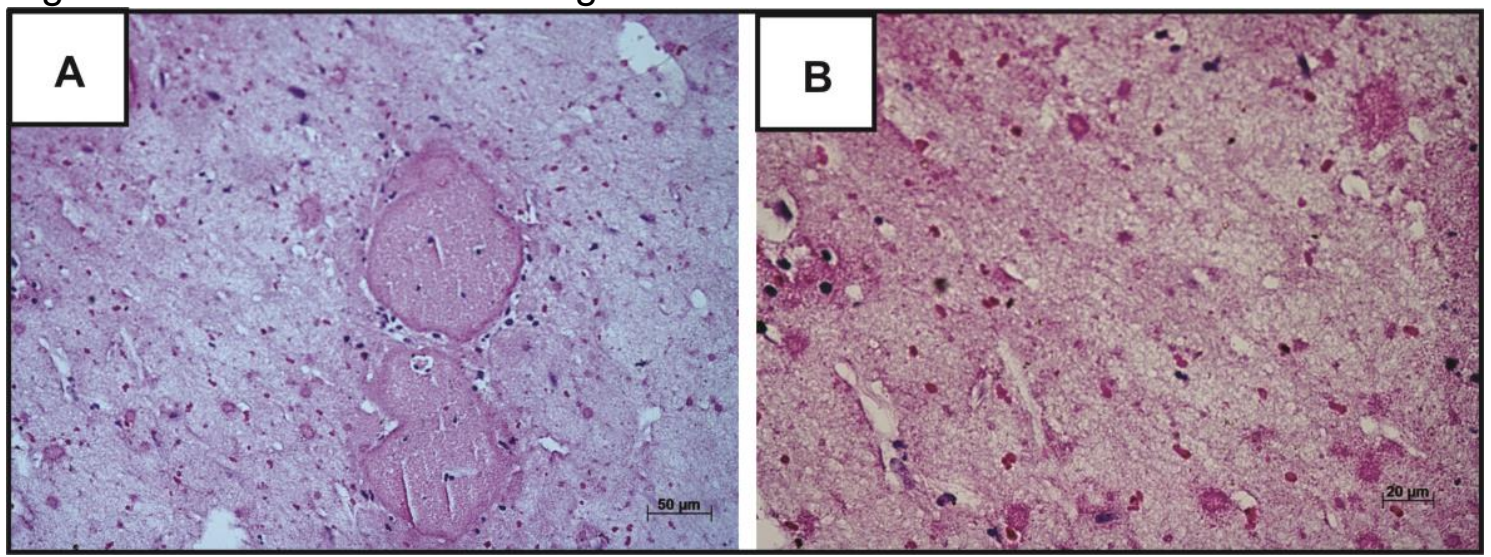

São observados núcleos de células corados em roxo e imersos na rede de fibrina, corada em rosa. A) Aumento de 20x. B) Aumento de 40x. Coloração: HE.

Amostras do gel de PRP contendo CT-TA foram cultivadas in vitro, por quatro dias, e foi possível observar, em acordo com a Figura 30, que as CT-TA podem migrar do interior do gel de PRP, rumo à superfície de cultura.

Figura 30 - Cultivo in vitro de CT-TA imersas no gel de PRP.

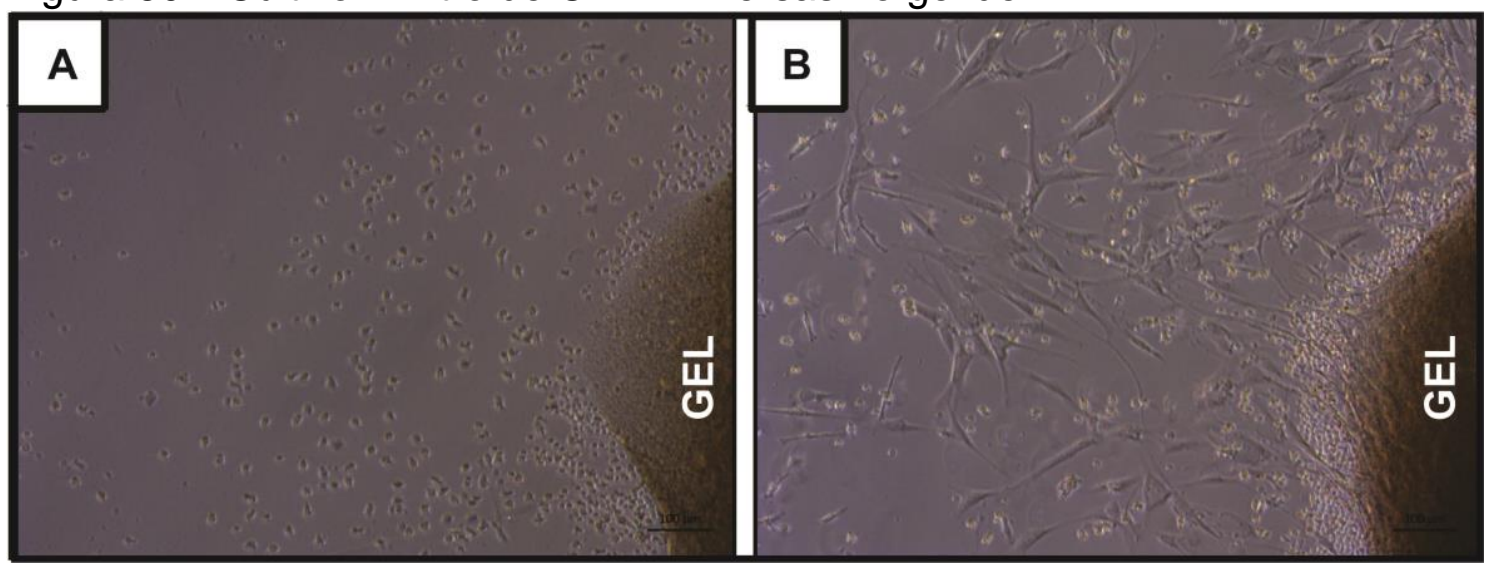

A região sombreada equivale ao gel de onde partem as CT-TA. A) 24 horas. B) 96 horas. Aumento de 10x. 


\subsection{Relação das úlceras, localização e cronicidade}

Dos seis pacientes selecionados, foram tratadas 10 úlceras cutâneas crônicas localizadas nos membros inferiores, em acordo com a Tabela 17.

Tabela 17 - Relação dos pacientes e características gerais das úlceras.

\begin{tabular}{lccc}
\hline Paciente & Úlceras & Localização das úlceras & $\begin{array}{c}\text { Histórico das úlceras } \\
\text { (meses) }\end{array}$ \\
\hline I & la & MIE, dorsal do pé & 12 \\
II & Ila & MIE, coto de amputação do hálux & Pós amputação \\
III & IIla & MID, calcânea & 9 \\
IV & IVa & MID, plantar & 6 \\
& IVb & MIE, maleolar lateral & 6 \\
V & Va & MIE, anterior da perna & 6 \\
& Vb & MIE, anterior da perna & 6 \\
& Vc & MIE, tendão de Aquiles, exposição do & 6 \\
& & tendão calcâneo & \\
& Vd & MID, maleolar posterior & 6 \\
VI & Vla & MID, plantar & 8 \\
\hline
\end{tabular}

MIE: membro inferior esquerdo.

MID: membro inferior direito.

Todas as lesões apresentaram histórico de cronicidade, ou ausência de cicatrização significante, por um período superior a seis meses, exceto do paciente II, que recebeu o tratamento após amputação realizada durante 0 cultivo das células.

\subsection{Evolução da cicatrização das úlceras pós-tratamento}

Após aplicação do implante de CT-TA, associadas ao gel de PRP, sobre o leito das úlceras, os pacientes foram acompanhados, em regime ambulatorial, para avaliação do aspecto das lesões e foto-documentação das úlceras. Desta forma, a área das lesões foi calculada e estão listadas na Tabela 18 para cada tempo de avaliação, a partir do dia da aplicação (dia 0) e o seguimento de 7, 14, 21, 28, 45, 60 e 90 dias após o início do tratamento. 
Tabela 18 - Valores absolutos das áreas ulcerosas obtidas durante 0 seguimento ambulatorial de cada paciente submetido à terapia.

\begin{tabular}{lcccccccc}
\hline Úlcera & $\mathbf{A}_{\mathbf{0}}$ & $\mathbf{A}_{\mathbf{7}}$ & $\mathbf{A}_{\mathbf{1 4}}$ & $\mathbf{A}_{\mathbf{2 1}}$ & $\mathbf{A}_{\mathbf{2 8}}$ & $\mathbf{A}_{45}$ & $\mathbf{A}_{60}$ & $\mathbf{A}_{\mathbf{9 0}}$ \\
\hline la & 2,185 & 1,918 & 1,651 & 1,591 & 1,088 & 0 & 0 & 0 \\
Ila & 12,597 & 12,449 & 9,302 & 9,542 & 9,780 & 8,100 & 8,137 & 4,297 \\
IIla & 3,992 & 4,496 & 4,813 & 3,163 & 4,018 & 2,092 & 2,466 & 2,166 \\
IVa & 0,317 & 0,077 & 0,037 & 0,117 & 0 & 0 & 0 & 0 \\
IVb & 1,227 & 0,898 & 0,653 & 0,509 & 0 & 0 & 0 & 0 \\
Va & 6,572 & 10,558 & 4,845 & 2,238 & 2,905 & 2,237 & 1,417 & 0 \\
Vb & 1,124 & 1,007 & 1,106 & 0,325 & 0 & 0 & 0 & 0 \\
Vc & 17,515 & 21,386 & 20,065 & 14,423 & 17,754 & 14,741 & 11,551 & 10,121 \\
Vd & 4,472 & 4,039 & 3,347 & 2,567 & 3,809 & 1,977 & 1,730 & 0,486 \\
Vla & 18,233 & 21,038 & 20,583 & 21,048 & 21,049 & 17,487 & 21,578 & 15,097 \\
\hline
\end{tabular}

At: Área ulcerosa em $\mathrm{cm}^{2}$ no tempo tem dias para cada lesão.

A verificação dos valores da Tabela 18, e do gráfico da Figura 31 indica a redução da área ulcerosa em todas as lesões. Ainda, a cicatrização total foi verificada em 5 das 9 lesões tratadas com CT-TA associadas a PRP.

Figura 31 - Variação da área ulcerosa para cada lesão no seguimento de 90 dias.

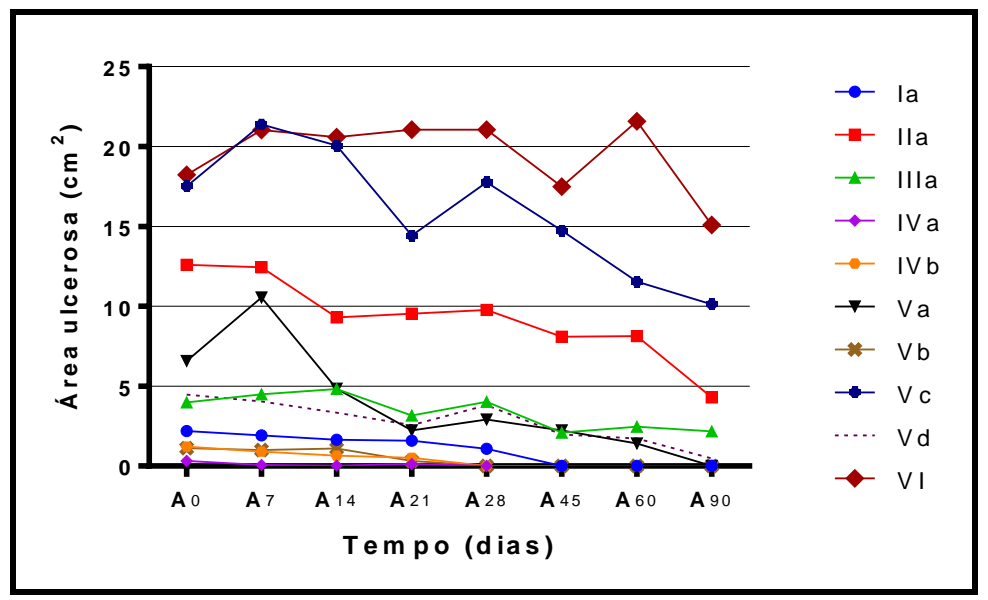

Com o propósito de verificar, estatisticamente, a diferença entre as áreas ulcerosas pré-tratamento e 90 dias após o início da terapia, foi realizado um teste t pareado, sendo o gráfico representado na Figura 32. 
Figura 32 - Medidas, em $\mathrm{cm}^{2}$, de cada lesão pré-tratamento e 90 dias após o início da terapia.

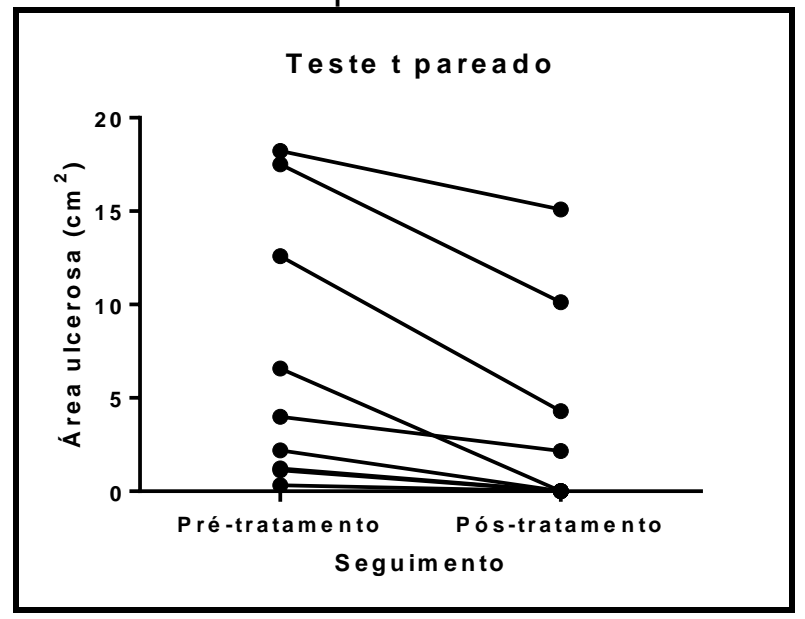

A partir do teste $t$ pareado foi obtido um valor de $p$ igual a 0,0077 $(p<0,05)$. Desta forma, é possível afirmar que existem evidências em nível de $5 \%$ de que há uma redução média na área ulcerosa, durante o período de 90 dias, em lesões crônicas de pacientes diabéticos submetidos à terapia com CTTA associadas ao gel de PRP. Ainda, o intervalo de confiança de $95 \%$ foi calculado e indica que a redução média da área ulcerosa está entre -5,890 e $1,239 \mathrm{~cm}^{2}$.

Os valores absolutos das áreas ulcerosas permitiram o cálculo dos IC, listados na Tabela 19, para cada tempo de avaliação, a partir da primeira semana após o dia da aplicação e o seguimento de 14, 21, 28, 45, 60 e 90 dias.

Tabela 19 - Índices de cicatrização (IC) obtidos durante o seguimento ambulatorial de cada úlcera por paciente submetido à terapia.

\begin{tabular}{lccccccc}
\hline Úlcera & $\mathbf{I C}_{\mathbf{7}}$ & $\mathbf{I C}_{\mathbf{1 4}}$ & $\mathbf{I C}_{\mathbf{2 1}}$ & $\mathbf{I C}_{\mathbf{2 8}}$ & $\mathbf{I C}_{\mathbf{4 5}}$ & $\mathbf{I C}_{\mathbf{6 0}}$ & $\mathbf{I C}_{\mathbf{9 0}}$ \\
\hline I & 12,21 & 24,43 & 27,18 & 50,20 & 100 & 100 & 100 \\
II & 1,17 & 26,15 & 24,25 & 22,36 & 35,69 & 35,40 & 65,88 \\
III & $-12,62$ & $-20,56$ & 20,76 & $-0,65$ & 47,59 & 38,22 & 45,74 \\
IVa & 75,70 & 88,32 & 63,09 & 100 & 100 & 100 & 100 \\
IVb & 26,81 & 46,78 & 58,51 & 100 & 100 & 100 & 100 \\
Va & $-60,65$ & 26,27 & 65,94 & 55,79 & 65,96 & 78,43 & 100 \\
Vb & 10,40 & 1,60 & 71,08 & 100 & 100 & 100 & 100 \\
Vc & $-22,10$ & $-14,55$ & 17,65 & $-1,36$ & 15,83 & 34,05 & 42,21 \\
Vd & 9,68 & 25,15 & 42,59 & 14,82 & 55,79 & 61,31 & 89,13 \\
VI & $-15,38$ & $-12,88$ & $-15,43$ & $-15,44$ & 4,09 & $-18,34$ & 17,19 \\
\hline
\end{tabular}

ICt: Índice de cicatrização, em porcentagem, no tempo t em dias para cada lesão. 
A análise da Tabela 19, semelhante à Tabela 18, indica a regressão da área ulcerosa de todas as lesões tratadas. Dinâmica e sistêmica, a cicatrização está estreitamente relacionada às condições gerais do paciente e à resposta de cada organismo. Desta forma, algumas lesões, com dimensões menores, cicatrizaram mais rapidamente (28 dias), ao passo as lesões maiores apresentaram resposta cicatricial mais tardia, inclusive com a oscilação da área ulcerosa durante o seguimento de 90 dias.

A Figura 33 mostra o seguimento de um dos casos onde é possível observar a partir da primeira semana após a aplicação do implante, a formação de uma crosta sobre o leito da lesão e a identificação de tecido de granulação sob a crosta. Ao longo do seguimento a crosta tornou-se mais espessa e em processo de contração até o desprendimento que revelou um tecido cicatrizado e reepitelizado, sem cicatrizes (Figura 33. F).

Figura 33 - Processo de cicatrização de uma lesão trófica na região dorsal do pé esquerdo (Paciente I).

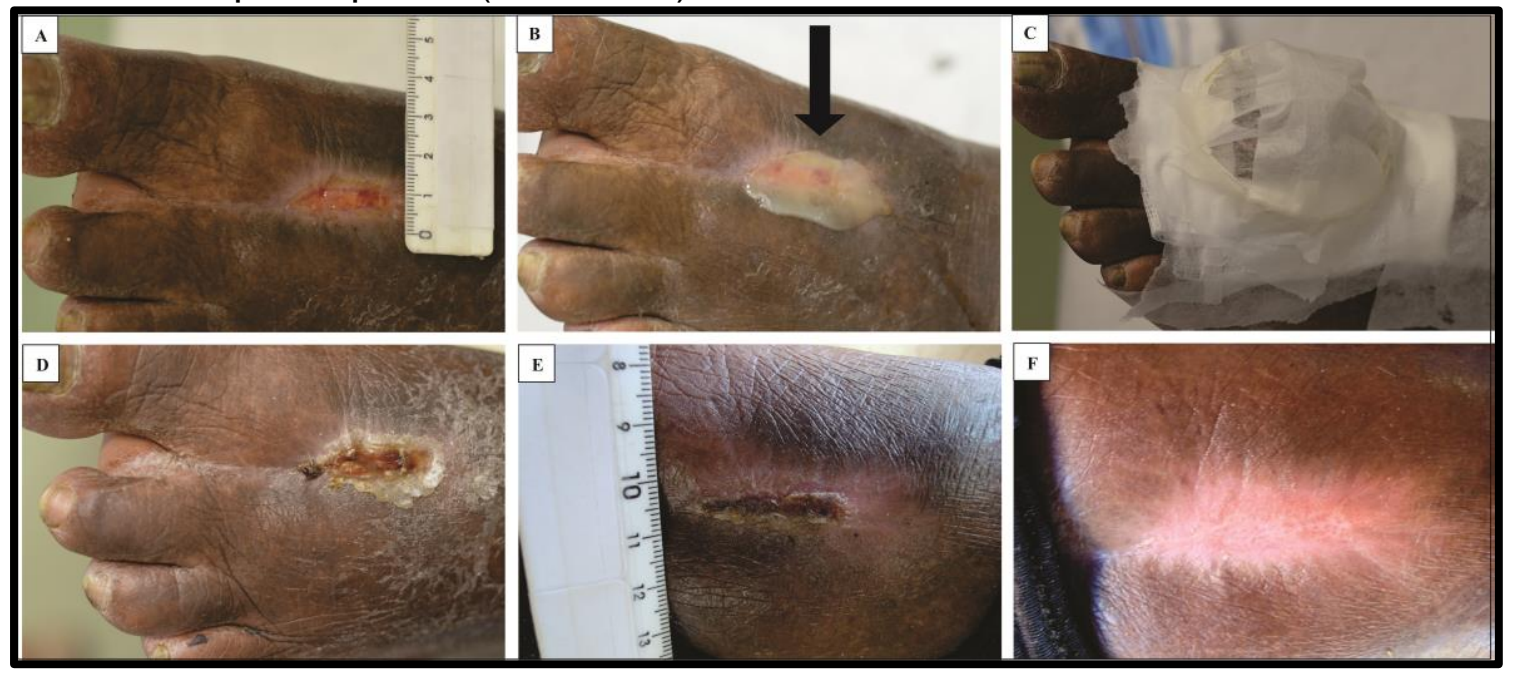

A) Úlcera pré-tratamento. B) Aplicação do gel de PRP e CT-TA. C) Cobertura do implante. D) Formação de crosta 7 dias após o implante. E) Espessamento e contração da crosta. F) Tecido cicatrizado e reepitelizado após 40 dias do implante.

No paciente V, com 4 lesões, 3 receberam o implante de PRP e CT-TA e 1 , na perna contralateral, recebeu apenas o implante de PRP, sem CT-TA. O seguimento de duas lesões, com tamanhos iniciais aproximados, está ilustrado na Figura 34. 
Figura 34 - Processo de cicatrização de duas lesões tróficas (Paciente V).
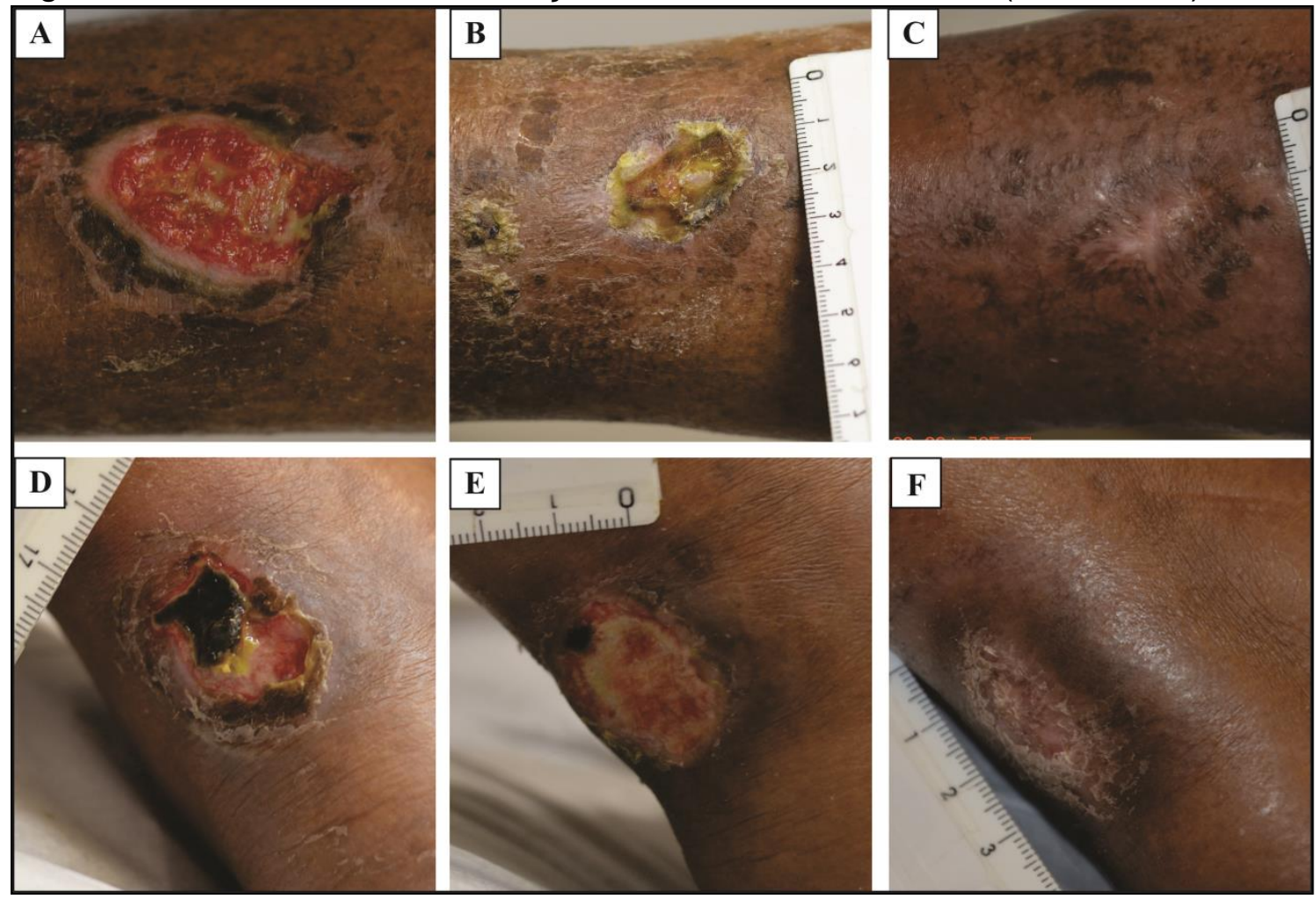

Lesão Va tratada com PRP e CT-TA, membro inferior esquerdo (A, B, C). Lesão Vd tratada apenas com PRP, membro inferior direito ( $D, E, F)$. A e D) Lesões pré-tratamento. $B$ e E) 28 dias após aplicação dos implantes (segundo implante de PRP sem CT-TA na lesão Vd). C e F) 90 dias após aplicação dos implantes.

A análise da Figura 34 mostra a diferença da aplicação do PRP com CTTA (A, B, C) e sem CT-TA (D, E, F). A lesão tratada sem CT-TA exigiu segunda aplicação de PRP, uma vez que foi verificada a estagnação do processo de cicatrização. Após 90 dias e dois implantes de PRP, não foi observado a resolução do processo de cicatrização na lesão $\mathrm{Vd}$, ao passo que a lesão $\mathrm{Va}$, tratada com uma aplicação de PRP e CT-TA, evidenciou completa regeneração e reepitelização. Essa diferença sinaliza a importância das CT-TA, associadas ao PRP, na aceleração do processo de cicatrização de úlceras crônicas em pacientes diabéticos.

Para avaliação da cicatrização em acordo com o tamanho das lesões, foi determinado, estatisticamente, um valor para classificação das úlceras em grandes e pequenas (BOSNARDO, 2010). O ponto de corte, obtido para este estudo, é equivalente à mediana das áreas ulcerosas iniciais $(n=10)$ e foi calculado em 4,232 $\mathrm{cm}^{2}$. Deste modo, úlceras acima do ponto de corte foram classificadas como grandes e as lesões abaixo do valor de corte, pequenas. $O$ 
gráfico da Figura 35 ilustra a diferença entre os índices de cicatrização entre as úlceras pequenas e grandes.

Figura 35 - Diferença entre lesões pequenas e grandes quanto aos índices de cicatrização obtidos após 90 dias de tratamento com CT-TA e PRP.

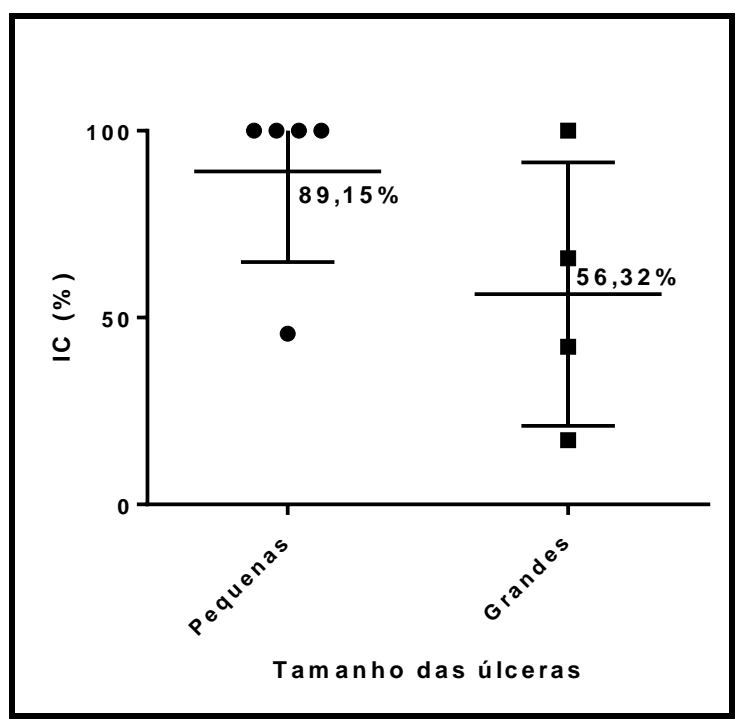

A análise da Figura 35 indica que as lesões menores apresentam índice médio de cicatrização maior $(89,15 \%)$ em comparação com a taxa média de fechamento das lesões maiores (56,32\%). Esses resultados sinalizam que, em um intervalo de tempo determinado, o tamanho das lesões influencia a cicatrização.

Com o propósito de verificar a relação entre o número de CT-TA implantadas e o IC, foi realizado o teste de correlação de postos de Spearman, sendo $r=0,8946$ e $p=0,0026$. $O$ gráfico da Figura 36 mostra a correlação dos índices de cicatrização com o número de CT-TA aplicadas. 
Figura 36 - Correlação entre o número de CT-TA (imersas no gel de PRP) aplicadas por $\mathrm{cm}^{2}$ de área ulcerosa e os índices de cicatrização obtidos após 90 dias do implante em úlceras crônicas de pacientes diabéticos.

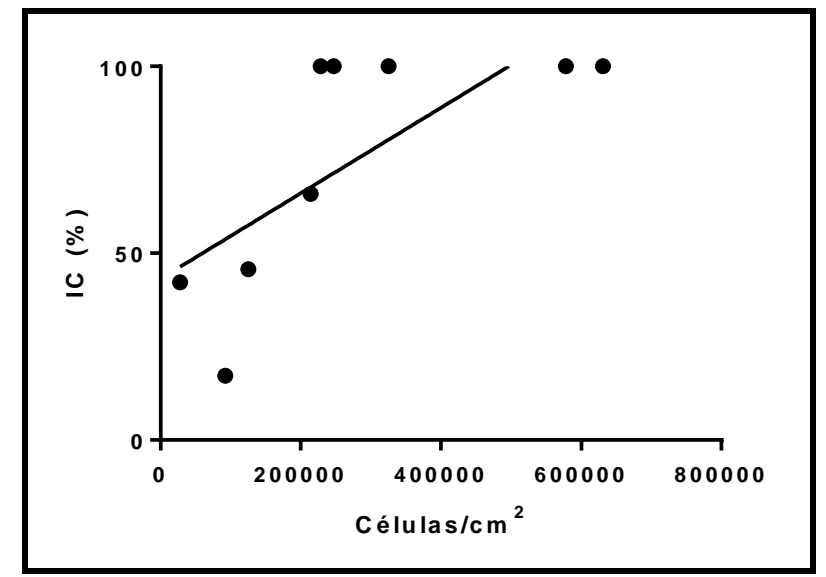

Esses resultados sugerem uma forte associação entre as variáveis número de CT-TA aplicadas por $\mathrm{cm}^{2}$ e o IC em um seguimento de 90 dias. Quanto maior o número de células aplicadas, maiores são os IC obtidos. 


\section{DISCUSSÃO}

As lesões ulcerosas de caráter crônico representam um grave e oneroso problema de saúde pública. Diferentes afecções patológicas de ordem sistêmica, como o diabetes mellitus, estão relacionadas à cronicidade das lesões nos membros inferiores. A perspectiva relacionada às úlceras crônicas de membros inferiores tende ao agravamento, considerando o aumento progressivo da população que se insere no grupo de risco, como indivíduos obesos e diabéticos (BREM et al., 2006).

O processo de cicatrização de feridas cutâneas é um evento biológico complexo, sendo necessária a participação de diversos tipos celulares, componentes da matriz extracelular e citocinas, com o propósito de restaurar a barreira e integridade da pele (SHAI; MAIBACH, 2005). O plasma rico em plaquetas (PRP), fração do plasma sanguíneo com elevada concentração plaquetária, tem sido empregado com o propósito de acelerar a cicatrização em diferentes áreas como odontologia, ortopedia, cirurgia plástica e dermatologia (MARQUES et al., 2015). O racional para o emprego do PRP na regeneração de lesões e reparo tecidual decorre da expressiva quantidade de fatores de crescimento, como PDGF, TGF, IGF e EGF, concentrados nas plaquetas e imprescindíveis para a cicatrização cutânea (SINGER; CLARK, 1999).

Apesar dos resultados consistentes relatados por diferentes grupos de pesquisa, em modelos experimentais e protocolos clínicos, quanto aos efeitos benéficos do PRP, sobretudo para recuperação de lesões osteoarticulares (MARQUES et al., 2015) e dermatológicas (GURGEN, 2008), há, na literatura, uma grande variação no que concerne à metodologia para obtenção do PRP (DRIVER et al., 2006; MARQUES et al., 2015; SHAN et al., 2013). A falta de padronização metodológica tem, certamente, afetado a reprodutibilidade de resultados tanto em modelos animais quanto em protocolos clínicos experimentais em pacientes humanos.

Neste cenário, buscou-se como um dos objetivos, deste estudo, avaliar comparativamente alguns dos aspectos de maior variação metodológica descritos na literatura, procurando, dessa forma, padronizar um método para a produção de um gel plaquetário, de forma eficiente, reprodutível e de baixo custo. A primeira etapa do processo de produção envolve a separação celular 
por centrifugação diferencial. Neste estudo, optou-se pelo método simplificado, com a utilização de centrífuga de uso ambulatorial, em virtude do baixo custo associado. Foram avaliados, comparativamente, seis protocolos, sendo três com uma etapa de centrifugação e três com duas etapas de centrifugação, conforme detalhado em 3.2.1 (Tabela 4).

Nos protocolos I, II e III, com uma única etapa de centrifugação é possível observar que quanto maior a rotação $(\mathrm{g})$, menor é a concentração de plaquetas e células sanguíneas (Tabela 6) e maior o volume de PRP ( $V_{\text {(p) PRP })}$ obtido (Tabela 7). Com relação à concentração plaquetária $\left(F_{\mathrm{CP}}\right)$, os resultados obtidos nos protocolos II $(1,300 \pm 0,160)$ e III $(1,013 \pm 0,041)$ são discordantes e inferiores em relação àqueles relatados na literatura, uma vez que estão aquém dos valores obtidos pelos autores proponentes dos protocolos II e III, cujos valores obtidos de $F_{C P}$ variaram, respectivamente, entre 2 a 3 (ANITUA et al., 2008) e 2,5 a 3 (ANITUA; TROYA; ORIVE, 2013). A disparidade entre os resultados pode estar relacionada à pequena amostragem, manipulação e variações durante pipetagem para coleta do PRP. Este método com uma etapa de centrifugação, portanto, não tem como propósito a concentração plaquetária, ao contrário, busca preservar maiores volumes de plasma, sendo indicado para o preenchimento de grandes áreas de lesão, como exemplo, o seio maxilar (SCARANTO, 2002).

Nos protocolos com duas centrifugações, IV, V e VI, observa-se, semelhante aos protocolos I, II e III que quanto maior a rotação $(\mathrm{g})$, menor é a concentração de plaquetas e células sanguíneas (Tabela 6) e maior o volume de plasma $\left(V_{(\text {pl)PS }}\right)$ e PRP $\left(V_{(\text {pl)PRP }}\right)$, bem como as eficiências na recuperação do

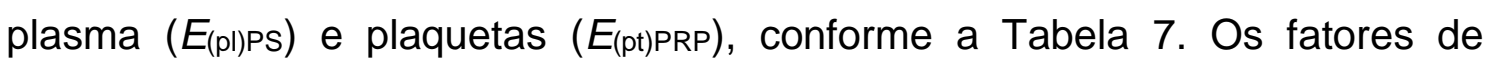
concentração plaquetária $\left(F_{\mathrm{CP}}\right)$ nos protocolos $\mathrm{V}$ e $\mathrm{VI}$, respectivamente, 2,400 $( \pm 0,090)$ e $2,050( \pm 0,226)$, foram maiores que os obtidos nos protocolos com uma centrifugação, porém discordantes e inferiores aos relatados na literatura, 5,7 (VENDRAMIN; FRANCO; FRANCO, 2009) e 4,2 (JO et al., 2013). A diferença pode ser explicada pela pequena amostragem, manipulação e pipetagem, uma vez que, neste estudo, o propósito, durante a coleta do plasma após a primeira centrifugação, foi evitar a coleta de hemácias e da região intermediária de névoa (buffy coat), rica em leucócitos, porém demasiadamente próxima em relação à maior concentração plaquetária. 
Há divergências quanto à manutenção de leucócitos na preparação do PRP. Em concentrações normais, os leucócitos participam no efeito imunomodulatório, liberando citocinas e fatores de crescimento, bem como proteases e radicais livres de oxigênio capazes de combater organismos invasores, mas também acabam por lesar o tecido hospedeiro (REED; CLARK, 1985). Desta forma, formulações com leucócitos devem ser empregadas com o propósito adicional de controlar infecções no local da úlcera, porém a ausência de leucócitos pode ser interessante para minimizar a ocorrência de cicatrizes (DELONG; RUSSELL; MAZZOCCA, 2012). Em acordo com as considerações supracitadas, foi escolhido e adotado neste estudo, o protocolo $\mathrm{VI}$, proposto por Jo e colaboradores (2013), onde é possível obter um PRP com pelo menos o dobro da concentração de plaquetas basais e com a menor concentração de leucócitos e neutrófilos, prevenindo ou minimizando, portanto, o desenvolvimento de cicatrizes in vivo.

Uma vez concentradas na fração plasmática, as plaquetas devem ser ativadas para que possa ocorrer a degranulação e consequente liberação dos fatores de crescimento, bem como a continuidade da cascata de coagulação e formação da rede de fibrina a partir do fibrinogênio. Os ativadores plaquetários comumente empregados são a trombina, cálcio (cloreto de cálcio e gluconato de cálcio a 10\%) e colágeno tipo I (DELONG; RUSSELL; MAZZOCCA, 2012).

Com o propósito de evitar a ativação precoce das plaquetas, bem como rejeição imunológica pela adição de componentes de origem animal (xenobióticos), optou-se pela ativação com gluconato de cálcio a 10\%. Desta forma, foram testados diferentes volumes de gluconato de cálcio a $10 \%(25 \mu \mathrm{L}$, $50 \mu \mathrm{L}, 100 \mu \mathrm{L}, 200 \mu \mathrm{L}$ e $300 \mu \mathrm{L}$ ) para cada $1000 \mu \mathrm{L}$ de PRP. Com $25 \mu \mathrm{L}$ de gluconato de cálcio a $10 \%$ para cada $1000 \mu \mathrm{L}$ de PRP não há detecção, macroscopicamente, de uma rede de fibrina, permanecendo o PRP em fase líquida com aspecto ligeiramente turvo, porém com consistência frouxa e baixa resistência mecânica. A partir de $50 \mu \mathrm{L}$ da solução de gluconato de cálcio a $10 \%$, há formação de uma membrana elástica, translúcida, extremamente fina. O aumento progressivo na concentração de cálcio proporciona a formação de géis mais espessos e resistentes, conforme está representado na Figura 10.

A adição de cálcio, contudo, abaixa o pH do PRP e, por este motivo, grandes quantidades de cálcio poderiam provocar ardor e sensação de 
queimadura (DELONG; RUSSELL; MAZZOCCA, 2012). A alteração de pH para cada proporção foi verificada e a variação máxima, produzida pela adição de $300 \mu \mathrm{L}$ de gluconato de cálcio a $10 \%$ por $1000 \mu \mathrm{L}$ de PRP, foi de 0,9 . Valores de pH entre 5,5 e 6,5 são aceitáveis e compatíveis com o pH cutâneo normal da pele saudável (ISAAC et al., 2008). Desta forma, o PRP adotado neste estudo apresenta um valor de $\mathrm{pH}$ entre 6,3 e 6,5, sendo que a maior quantidade de gluconato de cálcio a $10 \%$ adicionado $(300 \mu \mathrm{L})$ altera o $\mathrm{pH}$ para 6,2 , dentro, portanto, dos valores aceitáveis para a faixa de normalidade do $\mathrm{pH}$ da pele humana. A literatura relata trabalhos com proporções de cálcio próximas às avaliadas (JO et al., 2013; KAKUDO et al., 2008; LUCARELLI et al., 2003; SHAN et al., 2013), contudo, não há estudos prévios que investiguem a alteração do $\mathrm{pH}$ em acordo com a quantidade de cálcio e/ou trombina adicionados.

Com relação ao processo de contração do gel (gelificação), após adição de agente ativador (cálcio, colágeno ou trombina), há o início da polimerização do fibrinogênio em uma rede de fibrina. Com o passar do tempo, uma fase líquida é liberada, correspondente ao soro com expressiva quantidade de fatores de crescimento e de coagulação, provenientes do processo de degranulação plaquetária. Decorridos 60 minutos da ativação, mais de 95\% dos fatores de crescimento são liberados dos a-grânulos (MARX, 2004), sendo que as plaquetas e o fibrinogênio permanecem na constituição do gel (JO et al., 2013). Neste estudo, após 1 hora da adição de ativador, é possível verificar, conforme apresentado no gráfico da Figura 11, que quanto maior a quantidade de cálcio adicionado, menor é o volume $(\mathrm{mL})$ de soro formado, respectivamente, $0,953 \pm 0,181(300 \mu \mathrm{L}), 0,960 \pm 0,115(200 \mu \mathrm{L}), 1,096 \pm 0,049$ $(100 \mu \mathrm{L})$ e 1,283 \pm 0,125 $(50 \mu \mathrm{L})$. Após 6 horas de ativação, a proporção de $100 \mu \mathrm{L}$ de gluconato de cálcio a $10 \%$ resulta no menor volume de soro liberado $(1,450 \pm 0,043 \mathrm{~mL})$. Porém, quanto menor a quantidade de cálcio adicionada, menor é o volume $(\mathrm{mL})$ de gel formado, após 6 horas, respectivamente, 1,066 \pm 0,057 (300 LL), 0,803 $\pm 0,015(200 \mu \mathrm{L}), 0,750 \pm 0,043(100 \mu \mathrm{L}), 0,516 \pm 0,076$ $(50 \mu \mathrm{L})$. Diante destes resultados e considerando a perspectiva de aplicação clínica, optou-se pela proporção de $100 \mu \mathrm{L}$, ou no máximo $200 \mu \mathrm{L}$, de gluconato de cálcio a $10 \%$ para cada $1000 \mu \mathrm{L}$ de PRP, buscando, dessa forma, produzir uma biomembrana, pouco espessa, flexível, resistente à manipulação, 
com $\mathrm{pH}$ de, aproximadamente, 6,5 (compatível com o $\mathrm{pH}$ da pele humana) e com reduzida liberação de soro durante contração, para evitar desconforto ao paciente.

Além da rica fonte de fatores de crescimento, o PRP pode atuar como um suporte (scaffold) para outros tipos celulares com propósito terapêutico como, por exemplo, células-tronco mesenquimais do tecido adiposo (BLANTON et al., 2009; XIE et al., 2012). A rede de fibrina, arcabouço do gel plaquetário, é associada a excelentes parâmetros de biocompatibilidade e biodegradabilidade (AHMED et al., 2011). Desta forma, com o propósito de aprimorar a terapia com fatores de crescimento presentes no PRP em úlceras crônicas de pacientes diabéticos (DRIVER et al., 2006; GURGEN, 2008; SHAN et al., 2013), foi investigada a ação do PRP sobre a proliferação e migração das CT-TA.

Brem e colaboradores (2004) propuseram que o emprego de fatores de crescimento, associado ou não com terapia celular, deve ser considerado quando não se obtém um processo de reparo ou cicatrização após 2 semanas de tratamento convencional. Desde então, diferentes autores se ocuparam com estudos experimentais in vitro e modelos animais in vivo, demonstrando que as CTM possuem a capacidade de estimular o processo de resolução de úlceras, a proliferação e migração celular, a síntese de colágeno e a angiogênese, bem como beneficiar a qualidade do reparo e promover a restauração funcional cutânea (HAIHONG; XIAOBING, 2012; HU et al., 2013; KIM et al., 2007; ZHAO et al., 2013). Esses achados experimentais e proposições teóricas fundamentaram a elaboração deste estudo, que propõe a associação de PRP com CT-TA cultivadas, como uma nova alternativa para tratamento de úlceras cutâneas de difícil cicatrização. Diante dos métodos e resultados conflitantes descritos na literatura (MARQUES et al., 2015), com relação ao emprego terapêutico do PRP, buscou-se, para consecução do objetivo geral deste estudo, a definição de parâmetros metodológicos que confiram reprodutibilidade e eficácia terapêutica decorrente da associação de PRP e CTTA.

Neste estudo, CT-TA foram cultivadas com diferentes concentrações de PRP, na ausência de SFB. Somente após 48 horas houve estímulo proliferativo e migratório das CTM cultivadas com 10\% de PRP em comparação com o 
grupo controle branco (sem suplemento), com diferença estatística significante $(p<0,05)$. Ainda, há uma relação dose-dependente, que se expressa de forma inversamente proporcional, qual seja, quanto maior concentração de PRP, menor o estímulo proliferativo, conforme se verifica nos resultados apresentados na Figura 17 (proliferação). Estes resultados estão em consonância com os relatados na literatura, onde é possível verificar estímulo proliferativo significante de CTM cultivadas com até 10\% de PRP (FORMIGLI et al., 2012; HUANG et al., 2009; KAKUDO et al., 2008; LUCARELLI et al., 2003). Em cultivos in vitro, altas concentrações de PRP limitam o crescimento celular, uma vez que as plaquetas liberam uma composição complexa de proteínas com atividade reguladora negativa, que poderia, desta forma, reduzir ou anular os efeitos dos fatores de crescimento (HSU; YUAN; TSENG, 2009). Ainda, enzimas proteolíticas encontradas no PRP, tais como colagenase, elastase, fosfatase ácida e catepsina poderiam, em altas concentrações, concorrer para a inibição do crescimento celular, conforme proposto por Mills e colaboradores (1968).

Kim e colaboradores (2013) propuseram que a cola de fibrina poderia oferecer um ambiente propício para sobrevivência das CTM. Os autores relataram viabilidade superior a $95 \%$ de CTM em cola de fibrina, sendo constante a produção de fatores de crescimento pelas CTM por um período de até 2 semanas. Neste trabalho, CT-TA imersas no gel de PRP são aprisionadas pela rede de fibrina, após ativação plaquetária com gluconato de cálcio a 10\%, conforme mostra a Figura 29 e, quando associadas ao gel de PRP e cultivadas in vitro, por até 96 horas sem troca do meio de cultura, tem a capacidade de sobreviver, migrar para fora do gel, rumo à superfície de cultura e proliferar, conforme a Figura 30. Propõe-se, portanto, diante das observações deste estudo e dos resultados relatados por outros autores (KIM et al., 2013; XIE et al., 2012) com metodologias semelhantes que, uma vez inseridas no gel de PRP ativado, as CT-TA poderiam responder aos produtos da degranulação plaquetária, liberados em um intervalo de tempo curto (equivalente à 60 minutos após ativação) e sobreviver, imersas na rede de fibrina residual, secretando fatores parácrinos.

A via de sinalização sensível à nutrientes, PI3K/AKT (fosfatidilinosito-3quinase), é uma rota metabólica que regula a proliferação, migração, apoptose 
e diferenciação celular (CHEN et al., 2013). Em células-tronco, a via PI3K/AKT é ativada por insulina, glicose, aminoácidos e fatores de crescimento, que estimula, em mamíferos, a síntese proteica via quinase alvo da rapamicina (mTOR) (OCHOCKI; SIMON, 2013). Assim, pode-se formular a hipótese de que os fatores de crescimento presentes no PRP poderiam ativar a via de sinalização PI3K/AKT das CTM e estimular o mecanismo parácrino via síntese protéica regulada por mTOR. Neste cenário, o emprego de PRP tem potencial para estimular, em baixas concentrações, a capacidade proliferativa e migratória de CTM in vitro e, em formulações mais concentradas para formação do gel e experimentação in vivo, possibilitar - hipoteticamente - a ação terapêutica de CTM, por meio da estimulação das vias metabólicas sensíveis a fatores de crescimentos. Mais estudos moleculares são, contudo, necessários para sustentar esta proposta.

Estabelecido o protocolo para produção e gelificação do PRP, bem como determinada a resposta proliferativa e migratória de CT-TA na presença de PRP, torna-se imprescindível a investigação in vitro da influência do concentrado plaquetário e MC proveniente de CT-TA sobre as principais células responsáveis pelo processo de resolução de úlceras cutâneas. Fibroblastos e queratinócitos foram cultivados em diferentes concentrações de PRP, meio condicionado ou ambos. A queda na proliferação, significativamente, é observada, semelhante às CT-TA, a partir de 24 horas de cultivo com altas concentrações de PRP em fibroblastos e queratinócitos, conforme os resultados apresentados nos gráficos da Figura 20.

Há descrições distintas na literatura com relação ao estímulo proliferativo produzido pelo PRP, em intervalos de tempo curtos, como 24 horas. Kakudo e colaboradores (2008) cultivaram fibroblastos da derme em diferentes concentrações de PRP e, após 24 horas, 10\% e 20\% de PRP inibiram a proliferação. $O$ estímulo proliferativo significante, contudo, foi verificado apenas no sétimo dia nas culturas com $10 \%$ de PRP. Os autores utilizaram o buffy coat e também obtiveram uma quantidade elevada de plaquetas $\left(132,26 \times 10^{4} / \mu \mathrm{L}\right)$, aproximadamente o triplo da empregada neste estudo $\left(476,66 \times 10^{3} / \mu \mathrm{L}\right)$. Estes resultados sinalizam, em consonância com os dados obtidos por este estudo, que em 24 horas não se verifica estímulo proliferativo do PRP sobre fibroblastos, porém, diferente do trabalho de Kakudo e colaboradores (2008), 
baixas concentrações de PRP com frações mínimas de leucócitos e neutrófilos não produzem efeito inibitório na proliferação (Figura 20).

Em estudo recente, Shan e colaboradores (2013) relataram que o melhor estímulo para o crescimento celular é obtido com $2 \times 10^{6}$ plaquetas $/ \mu \mathrm{L}$, porém os autores realizaram leucodepleção do PRP e obtiveram crescimento significante de queratinócitos humanos $\mathrm{HaCaT}$ a partir de 24 horas de cultivo com $10 \%$ de PRP. Estes resultados indicam que não apenas concentrações mais elevadas de plaquetas no PRP, mas também a ausência de leucócitos podem contribuir para a proliferação de fibroblastos e queratinócitos em um intervalo de tempo curto. Neste sentido, a ausência de estímulo proliferativo em queratinócitos expostos ao PRP pode estar relacionada, neste estudo, à presença de leucócitos e neutrófilos, mesmo em frações mínimas, bem como à quantidade menor de plaquetas no PRP.

Em 48 horas, fibroblastos cultivados com 10\% e 25\% de PRP, 100\% de MC, bem como $25 \%$ de PRP e $25 \%$ de MC apresentaram comportamento proliferativo significante em comparação com o grupo controle branco (Tabela 10). Os queratinócitos, após 48 horas, proliferaram mais quando cultivados com $25 \%, 50 \%$ e $100 \%$ de MC (Tabela 11). A exposição ao PRP in vitro, em baixas concentrações, a partir de 48 horas, semelhante às CT-TA supracitadas, estimula o crescimento de fibroblastos (ANITUA; TROYA; ORIVE, 2013; KAKUDO et al., 2008; ROUBELAKIS et al., 2014) e queratinócitos (PARK; YANG; CHUNG, 2011; SHAN et al., 2013).

Com relação ao MC, proveniente de CT-TA, o estímulo proliferativo é verificado em fibroblastos e queratinócitos a partir de 24 horas, sendo que quanto maior a concentração de MC, maior o estímulo proliferativo (Figura 21). O meio condicionado proveniente de CTM contém uma fração rica em fatores solúveis com ação parácrina sobre fibroblastos e queratinócitos, tais como EGF, FGF, KGF, IGF-1, VEGF, PDGF (CHEN et al., 2008; DA SILVA MEIRELLES; CAPLAN; NARDI, 2008; KIM et al., 2007), citocinas de considerável importância durante o reparo de úlceras. Zhao e colaboradores (2013) demonstraram que a proliferação de fibroblastos é dependente de EGF e bFGF, presentes no MC e no PRP, o que também poderia explicar, neste estudo, a expansão celular verificada com $25 \%$ de PRP e $25 \%$ de MC, sob 
possível ação sinérgica ou aditiva, conforme verificado nos gráficos da Figura 22.

A citocina mitógena KGF, produzida por células de origem mesodermal, como CT-TA, presente no MC (CHEN et al., 2008; KIM et al., 2007), tem demonstrado exercer papel significante na proliferação, migração e diferenciação de células epiteliais, atuando como um mediador parácrino da comunicação mesenquimal-epitelial e contribuindo para o processo de cicatrização (SINGER; CLARK, 1999). Nos queratinócitos cultivados com PRP não foi observado efeito proliferativo significante. Este resultado pode ser explicado pelo baixo número de plaquetas e pela presença de leucócitos, mesmo em quantidades mínimas (SHAN et al., 2013). Ao contrário, as células epidermais respondem melhor do que fibroblastos ao MC, rico em KGF, em uma maneira dose-dependente (LEE et al., 2012), o que poderia explicar a resposta proliferativa dos queratinócitos ao MC de CT-TA (Figura 21. B).

Com relação à capacidade migratória, Park e colaboradores (2011) verificaram que $10 \%$ de PRP estimula a migração de fibroblastos, em 24 horas, todavia, semelhante aos ensaios de proliferação, os autores utilizaram um PRP com 3 vezes mais plaquetas que 0 adotado neste estudo. A baixa concentração de $M C$ também não foi suficiente para estimular a migração, contudo concentrações maiores de $M C$ são capazes de, semelhante ao comportamento expansivo, induzir a migração, tais como 50\% de MC (HU et al., 2013) e $100 \%$ de MC (WALTER et al., 2010). Os resultados do presente estudo mostraram que no ensaio de migração, ou cicatrização in vitro, os fibroblastos não apresentam comportamento migratório significante quando cultivados com $10 \%$ de PRP. Por outro lado, a migração de fibroblastos parece ser dependente de bFGF, VEGF e PDGF (ZHAO et al., 2013), o que poderia embasar o resultado obtido neste estudo sobre o estímulo proliferativomigratório apenas quando da associação do PRP e MC, ambos em baixas concentrações, sinalizando uma ação sinérgica ou aditiva de duas abordagens terapêuticas, qual sejam, o PRP e CT-TA.

Novas terapias, no contexto da medicina regenerativa com propósito dermatológico, são de extrema relevância clínica, ainda que resultados preliminares, porém extremamente promissores envolvendo células-tronco e moléculas bioativas, indicam a eficácia para o tratamento de lesões cutâneas 
de difícil cicatrização (CERVELLI; GENTILE; GRIMALDI, 2009; FALANGA et al., 2007; GAME et al., 2016). O diabetes mellitus, um grande vilão da sociedade moderna, alastra-se em proporções epidêmicas e, em 2030, projetase que 439 milhões de pessoas serão afetadas, sendo grande a preocupação associada às complicações, como o aparecimento de lesões cutâneas nos membros inferiores e amputações (CAVANAGH et al., 2012; WILD et al., 2004;. Deste modo, úlceras cutâneas crônicas, em especial de pacientes diabéticos, são consideradas, apesar dos avanços quanto aos aspectos patológicos e terapêuticos, como um grave e oneroso problema de saúde pública, bem como um enorme desafio social e científico.

Neste estudo, lesões tróficas crônicas, revascularizadas, de 6 pacientes diagnosticados com diabetes mellitus tipo II foram submetidas à terapia autóloga composta por uma membrana (gel) de PRP associada a CT-TA. A primeira etapa compreendeu a coleta de uma quantidade mínima de tecido adiposo, inferior a $5 \mathrm{~g}$ por paciente. Não há trabalhos, em pacientes humanos, que reportem a quantidade de tecido adiposo coletado por paciente com 0 propósito de isolamento das CT-TA para regeneração cutânea. Os artigos publicados têm como objetivo a coleta da FVE para aplicação imediata em úlceras crônicas e pós-traumáticas nos membros inferiores, sem técnicas de cultivo celular e, por esta forma, sendo necessárias quantidades maiores de tecido adiposo, próximo a $60 \mathrm{~mL}$ (CERVELLI; GENTILE; GRIMALDI, 2009; CERVELLI et al., 2011).

As triagens clínicas em andamento, ou recém-concluídas, que envolvem técnicas de cultivo para expansão das CT-TA, não mencionam, nas plataformas de registro junto ao site americano ClinicalTrials (www.clinicaltrials.gov), a quantidade de tecido adiposo coletada por paciente. Deste modo, o método de coleta empregado neste estudo, mediante anestesia local, pequena incisão, pequena quantidade de material coletado, bem como a ausência de relatos, por parte dos pacientes, associados a desconforto ou incômodo gerado no momento ou após a coleta, indicam que a estratégia adotada para obtenção do tecido adiposo é minimamente invasiva e sem efeitos adversos, diferente do que ocorre em procedimentos de punção de medula óssea para isolamento de CT ou da fração mononuclear (FALANGA et al., 2007). 
Mesmo com pequena quantidade de tecido adiposo, foi possível isolar CT-TA de cada paciente, com aspecto fibroblastoide (Figura 25), características imunofenotípicas (Tabela 14) e diferenciação multipotencial (Figuras 26, 27 e 28), em acordo com o proposto pela Sociedade Internacional de Terapia Celular para caracterização e validação de CTM (DOMINICl et al., 2006). Em cerca de 3-4 semanas foram obtidas aproximadamente $10^{7}$ células de cada paciente, destinadas aos ensaios de diferenciação, imunofenotipagem e à terapia.

Quanto à produção do PRP autólogo, foi verificado o aumento da concentração de plaquetas no plasma de cada paciente, sendo o fator de concentração plaquetária $\left(F_{C P}\right)$ próximo a 2 (Tabela 16), e a redução acentuada de hemácias e leucócitos (Tabela 15), diminuindo assim a formação de cicatrizes (DELONG; RUSSELL; MAZZOCCA, 2012; JO et al., 2013). As diferenças encontradas nas eficiências de recuperação do plasma e das plaquetas podem ser esclarecidas por variações durante a pipetagem para coleta do plasma e concentração do PRP, bem como pela variação individual. Contudo, de uma maneira geral, os resultados relativos à quantificação dos componentes sanguíneos no PRP estão de acordo com a padronização realizada, neste estudo, segundo o protocolo proposto por Jo e colaboradores (2013).

A gelificação do PRP, após associação com as CT-TA e adição de gluconato de cálcio a 10\%, ocorreu em superfície plana para produzir uma biomembrana flexível, pouco espessa e resistente à manipulação, com a forma e tamanho de cada lesão. Este método provou ser eficaz, uma vez que dispensa o uso de trombina, geralmente de origem animal em kits comerciais e nos trabalhos relatados na literatura para aplicação tópica (DRIVER et al., 2006; KONTOPODIS et al., 2016; SHAN et al., 2013). Ainda, a membrana ou película de PRP autólogo, desenvolvida neste estudo, proporciona cobertura total e uniforme da lesão e, em decorrência da matriz de fibrina, é aderente à área ulcerosa (BOSNARDO, 2010; FALANGA et al., 2007). Nos demais trabalhos da literatura com aplicação tópica de PRP, os coágulos são colocados sobre as lesões, mas não de maneira uniforme, tanto em modelos animais, com associação de CTM (ARGÔLO NETO et al., 2012; BLANTON et al., 2009) e em pacientes humanos sem associação de CT (DRIVER et al., 
2006; KONTOPODIS et al., 2016; SHAN et al., 2013). Ainda, nos trabalhos com injeção intra/peri lesional para tratamento de úlceras crônicas ou pós traumáticas, também o gel de PRP, associado à fração vascular estromal, não é distribuído uniformemente (CERVELLI; GENTILE; GRIMALDI, 2009; CERVELLI et al., 2011).

Sobre a cicatrização das lesões, neste estudo, de maneira semelhante a outros trabalhos envolvendo terapia celular com o uso de scaffolds biológicos para o tratamento de lesões crônicas (BOSNARDO, 2010), foi observado clinicamente que, as úlceras com crostas mais precoces, responderam melhor ao tratamento, ultrapassando a fase inflamatória e evoluindo rapidamente para a reepitelização ou resolução total do processo ulceroso. De maneira geral, o fechamento ou reepitelização das úlceras ocorreu das bordas para o centro, sendo observada a formação de tecido de granulação, crostas e consequente preenchimento das lesões mais profundas, já nas primeiras semanas após a aplicação. Ainda, não foram constatadas hipertrofias cicatriciais ou retrações, sendo, portanto, satisfatório o resultado cosmético (Figuras 33. F e 34. C).

Neste estudo, das 9 úlceras crônicas, provenientes de 6 pacientes com diabetes mellitus tipo II, tratadas com PRP associado à CT-TA por via tópica, houve $100 \%$ de reepitelização em 5 lesões (55\%), em 90 dias de seguimento após o início do tratamento. Em todas as lesões foi observada uma tendência para o declínio da área ulcerosa (Figura 31) e, consequentemente, o aumento do índice de cicatrização, como se verifica na Tabela 19. Deste modo, é possível verificar, significativamente $(\mathrm{p}<0,05)$, uma redução média na área ulcerosa das lesões crônicas de pacientes diabéticos submetidos à aplicação de uma biomembrana de PRP associada à CT-TA (Figura 32), sendo a redução média estabelecida entre $-5,890$ e $-1,239 \mathrm{~cm}^{2}$. Não há, relatado na literatura, dados e metodologias semelhantes que permitam comparações efetivas, contudo algumas aproximações são pertinentes.

Em 2007, Falanga e colaboradores cultivaram CTM da medula óssea e associaram a um spray de fibrina para aspersão sobre o leito de seis úlceras crônicas. Em apenas uma lesão (com histórico de dez anos) foi observado $100 \%$ de re-epitelização. Quatro lesões atingiram índice de cicatrização médio de $40 \%$ e uma lesão não sofreu alterações significantes após o tratamento, em 20 semanas de observação. Desde modo, estes resultados sinalizam maior 
eficácia associada à CT-TA em combinação com PRP, provavelmente em decorrência da maior disponibilidade de moléculas bioativas, provenientes das plaquetas, bem como uma possível ação sinérgica com CT-TA. Essa hipótese é reforçada também pelo trabalho de Cervelli e colaboradores (2009), onde foi observada, após 9,7 semanas, completa reepitelização em 16 de 20 úlceras tratadas com aplicações intra/peri lesionais de PRP associado ao tecido adiposo.

Com o propósito de avaliar a importância e relevância das CT-TA no processo de cicatrização, a lesão $(\mathrm{Vd})$, localizada na perna contralateral às 3 outras lesões $(\mathrm{Va}, \mathrm{Vb}$ e $\mathrm{Vc}$ ) do paciente $\mathrm{V}$, recebeu apenas a biomembrana de PRP, sem CT-TA. Após 4 semanas da aplicação, foi necessária nova intervenção, assim como as demais úlceras (Vc e Vla), onde não foi observada regressão da área ulcerosa ou cicatrização significante em 30 dias, sendo este prazo relativo ao menor período de completa cicatrização encontrado, neste estudo, e segundo proposição de Bosnardo (2010). É válido ressaltar que as lesões Vc e Vla, além de grandes proporções (maiores que $17 \mathrm{~cm}^{2}$ ) e profundidade, estavam associadas à complicações, respectivamente, isquemia crítica e osteomielite grave, o que poderia ter prejudicado a cicatrização e provocado a necessidade de novas intervenções. Em contrapartida, a lesão Vd, livre de complicações, mas tratada apenas com PRP, exigiu nova aplicação e, após 90 dias, alcançou 89,13\% de cicatrização, inferior aos 100\% alcançado pela lesão Va, do mesmo paciente, que recebeu também CT-TA (Figura 34). Embora não seja viável a análise quantitativa para estabelecer uma possível diferença estatística entre as lesões tratadas com PRP+CT-TA ou apenas PRP, os resultados obtidos neste estudo estão de acordo com outros trabalhos relatados na literatura, também realizados com pequena amostragem, mas que indicam a importância e eficiência das CT-TA, associadas ao PRP, para acelerar a cicatrização cutânea (CERVELLI; GENTILE; GRIMALDI, 2009; CERVELLI et al., 2011; FALANGA et al, 2007).

Estudos realizados em pacientes diabéticos, que utilizam apenas o PRP como tratamento de úlceras cutâneas crônicas, são observados índices de cicatrização superiores a $90 \%$ na maioria das lesões, todavia são realizadas cerca de duas aplicações por semana, totalizando mais de 10 sessões ao longo da terapia (KONTOPODIS et al., 2016; SHAN et al., 2013). Novamente, 
esses resultados, aliados aos dados obtidos neste estudo, sinalizam a importância da associação da terapia celular ao tratamento com PRP, ou matriz de fibrina, sendo necessárias, no máximo, 4 aplicações (CERVELLI; GENTILE; GRIMALDI, 2009; CERVELLI et al., 2011; FALANGA et al, 2007).

Sobre a quantidade de CT-TA aplicadas por unidade de área ulcerosa e a reepitelização obtida, foi encontrada uma forte $(r=0,8946)$ e estatisticamente significante $(p=0,0026)$ correlação, id est, quanto maior o número de células aplicadas por $\mathrm{cm}^{2}$, maior o índice de cicatrização em \%, após 90 dias do início do tratamento (Figura 36). A correlação referente ao aumento do número de CTM e o estímulo da cicatrização em úlceras cutâneas crônicas é também coerente com os resultados obtidos por Falanga e colaboradores (2007) e compõem dados de extrema importância para estudos futuros com maior número de pacientes.

Com o propósito de investigar e melhor estudar a eficácia do tratamento em acordo com a área das lesões, a mediana relativa às áreas ulcerosas da amostra foi obtida e, desta forma, as feridas foram classificadas em grandes e pequenas, segundo proposição de Bosnardo (2010). Observou-se diferentes índices de cicatrização para as úlceras grandes e pequenas, respectivamente, $56,32 \%$ e $89,15 \%$, após 90 dias. Deste modo, em um intervalo de tempo determinado (90 dias), o tamanho das lesões influencia na resposta ao tratamento, sendo que as úlceras menores cicatrizam mais rapidamente e as maiores são mais resistentes e menos responsivas, como também observado por outros autores (BOSNARDO, 2010). Neste cenário, há a possibilidade de que as lesões maiores necessitem de mais aplicações durante um tempo maior de acompanhamento, proporcionalmente e em decorrência da maior área ulcerosa.

Não apenas o tamanho da lesão, mas também outros fatores além do diabetes mellitus, podem influenciar a resistência ao tratamento, como exemplo, a idade avançada que, consequentemente, está atrelada às doenças vasculares e insuficiência vascular. Todos os indivíduos que participaram do estudo tem idade superior a 55 anos, são pacientes do ambulatório da Cirurgia Vascular e passaram por procedimentos de revascularização. Ainda, como consequência da idade, o processo de cicatrização está prejudicado, uma vez que há anormalidades na angiogênese, reepitelização e na infiltração de 
macrófagos e células T (GOULD et al., 2015). Nas pacientes III e VI, com os menores índices de cicatrização $(<50 \%)$ e idades superiores a 70 anos, há a possibilidade do fator hormonal ter prejudicado a cicatrização, uma vez que, em mulheres no período pós menopausa, são encontrados altos níveis de metaloproteinases, especialmente MMP2 (ASHCROFT et al., 1997), o que prejudicaria a ação dos fatores de crescimento.

Um fator associado à eficácia da terapia proposta e executada, neste estudo, é concernente à qualidade das células aplicadas sobre as lesões. Mesmo provenientes de pacientes diabéticos, as CT-TA foram capazes de expressar os antígenos de superfície (Tabela 14), adquirir a morfologia fibroblastoide (Figura 25), proliferar e diferenciar nas linhagens adipogênica, condrogênica e osteogênica (Figuras 26, 27 e 28) sob estímulo e cultivo in vitro, bem como participar na cicatrização de lesões cutâneas crônicas, em associação com o PRP. Estes resultados concordam com a literatura, uma vez que CT-TA, proveniente de modelo animais diabéticos, são capazes de proliferar e produzir citocinas e fatores de crescimento, na mesma proporção que CT-TA sem o fenótipo diabético. Ao contrário, células terminantemente diferenciadas, como fibroblastos e queratinócitos, provenientes de modelos animais ou pacientes diabéticos, apresentam a proliferação, migração e produção de moléculas bioativas prejudicadas (GOULD et al., 2015; NAMBU et al., 2009, 2011). Coletivamente, esses resultados sinalizam que a utilização de CTM pode ser mais adequada do que células adultas especializadas para 0 tratamento de lesões cutâneas crônicas de pacientes diabéticos.

A relevância da terapia proposta, neste trabalho, está associada ao estímulo significante para a cicatrização de úlceras crônicas, além do relativo baixo custo, em comparação com dispositivos comerciais de alto custo compostos por matrizes degradáveis, que necessitam de substituições frequentes. Embora não desprezíveis, os gastos com a produção da biomembrana de PRP na forma gel são consideravelmente inferiores aos custos concernentes à utilização de selante de fibrina comercial, ou mesmo autólogo. Ainda, a terapia é integralmente autóloga e não foram observadas reações adversas, o que denota a segurança da abordagem terapêutica.

O saber científico relativo à bioengenharia tecidual e terapia celular está na infância. São ainda imprescindíveis a ampliação do conhecimento e o 
aperfeiçoamento da produtividade intrínseca às CT-TA, verdadeiras biofábricas, bem como às plaquetas, que trabalham diariamente em favor do ser humano. Deste modo, o presente trabalho colabora com fundamentações hipotéticas, teóricas e práticas para alicerçar e fortalecer futuros estudos relacionados ao tratamento de úlceras cutâneas crônicas. 


\section{CONCLUSÕES}

A execução dos experimentos propostos no presente trabalho e os resultados obtidos permitem concluir que:

- Após avaliação de diferentes protocolos para obtenção de fração rica em plaquetas é possível concluir que a produção de plasma rico em plaquetas (PRP) na forma gel pode ser obtida mediante metodologias livres de componentes de origem animal (xenobióticos), sendo o produto final uma biomembrana pouco espessa, flexível e resistente à manipulação, com propriedades físico-químicas compatíveis com a fisiologia cutânea e conforto do paciente.

- O PRP estimula a proliferação e migração de células-tronco mesenquimais derivadas do tecido adiposo (CT-TA) in vitro.

- O PRP e o meio condicionado proveniente de CT-TA estimulam a proliferação e migração de fibroblastos da derme in vitro.

- O meio condicionado proveniente de CT-TA estimula a proliferação de queratinócitos in vitro.

- A aplicação de CT-TA associadas ao PRP, por via tópica, proporciona uma redução média na área ulcerosa de lesões cutâneas crônicas de pacientes diabéticos.

- Os implantes de CT-TA associadas ao PRP apresentam potencial eficácia e compõem uma alternativa promissora para o tratamento de úlceras cutâneas crônicas de pacientes diabéticos.

- Não foram observadas reações adversas ou rejeição ao implante de CT-TA associadas ao PRP, ambos autólogos, por via tópica, o que sinaliza a segurança da terapia proposta. 


\section{REFERÊNCIAS*}

AGALE, S.V. Chronic leg ulcers: epidemiology, aetiopathogenesis, and management. Ulcers, v. 2013, n. 413604, p. 1-9, 2013.

AGGARWAL, S.; PITTENGER, M.F. Human mesenchymal stem cells modulate allogenic immune cell responses. Blood, v. 105, n. 4, p. 1815-1822, 2005.

AHMED, T.A.E. et al. Fibrin glues in combination with mesenchymal stem cells to develop a tissue engineered cartilage substitute. Tissue Engineering Part A, v. 17, n. 3, p. 323-335, 2011.

AMABLE, P.R. et al. Platelet-rich plasma preparation for regenerative medicine: optimization and quantification of cytokines and growth factors. Stem Cell Research \& Therapy, v. 4, n. 3, p. 67-80, 2013.

AMATO, B. et al. The role of adult tissue-derived stem cells in chronic leg ulcers: a systematic review focused on tissue regeneration medicine. International Wound Journal, 2015. In press.

ANITUA, E. et al. Effectiveness of autologous preparation rich in growth factors for the treatment of chronic cutaneous ulcers. Journal of Biomedical Materials Research. Part B Applied Biomaterials, v. 84, n. 2, p. 415-421, 2008.

ANITUA, E.; TROYA, M.; ORIVE, G. An autologous platelet-rich plasma stimulates periodontal ligament regeneration. Journal of Periodontology, v. 84, n. 11, p. 1556-1566, 2013.

ASHCROFT, G.S. et al. Age-related differences in the temporal and spatial regulation of matrix metalloproteinases (MMPs) in normal skin and acute cutaneous wounds of healthy humans. Cell and Tissue Research, v. 290, n. 3, p. 581-591, 1997.

ARGÔLO NETO, N.M. et al. Role of autologous mesenchymal stem cells associated with platelet-rich plasma on healing of cutaneous wounds in diabetic mice. Clinical and Experimental Dermatology, v. 37, n. 5, p. 544-553, 2012.

BALTZIS, D.; ELEFTHERIADOU, I.; VEVES, A. Pathogenesis and treatment of impaired wound healing in diabetes mellitus: new insights. Advances in Therapy, v. 31, n. 8, p. 817-836, 2014.

BARRIENTOS, S. et al. Growth factors and cytokines in wound healing. Wound Repair and Regeneration, v. 16, n. 5, p. 585-601, 2008.

\footnotetext{
"De acordo com:

ASSOCIAÇÃO BRASILEIRA DE NORMAS TÉCNICAS. NBR 6023: informação e documentação:

referências: elaboração, Rio de Janeiro, 2002.
} 
BLANTON, M. W. et al. Adipose stromal cells and platelet-rich plasma therapies synergistically increase revascularization in wound healing. Plastic and Reconstructive Surgery, v. 123, n. 2S, p. 56S-64S, 2009.

BOSNARDO, C.A.F. Análise clínica prospectiva randomizada aberta, do tratamento das úlceras venosas, através da terapia celular com o enxerto de queratinócitos autólogos; comparada em dois grupos, associado ou não, a Diosmina Hesperidina Micronizada.2010. 123 f. Tese (Doutorado em Cirurgia) - Faculdade de Ciências Médicas, Universidade Estadual de Campinas, Campinas, 2010.

BREM, H.; SHEEHAN, P.; BOULTON, A.J. Protocol for treatment of diabetic foot ulcers. American Journalof Surgery,v. 187, n. 5A, p. 1S-10S, 2004.

BREM, $\mathrm{H}$. et al. Evidence-based protocol for diabetic foot ulcers. Plastic and Reconstrutive Surgery, v. 117, p. 193S-209S, 2006. Suplemento 7.

BUNNELL, B.A. et al. Adipose-derived stem cells: isolation, expansion and differentiation. Methods, v. 45, n. 2, p. 115-120, 2008.

BURKHART, J.M. et al. The first comprehensive and quantitative analysis of human protein composition allows the comparative analysis of structural and functional pathways. Blood, v. 120, n. 15, p. e73-e82, 2012.

CAPLAN, A.L. Mesenchymal stem cells. Journal of Orthopaedic Research, v. 9, n. 5, p. 641-650, 1991.

CARR, M.E. In vitro assessment of platelet function. Transfusion Medicine Reviews, v. 11, n. 2, p. 106-115, 1997.

CARTER, C. A. et al. Platelet-rich plasma gel promotes differentiation and regeneration during equine wound healing. Experimental and Molecular Pathology, v. 74, n. 3, p. 244-255, 2003.

CASTILLO, T.N. et al. Comparison of growth factor and platelet concentration from commercial platelet-rich plasma separation systems. The American Journal of Sports Medicine, v. 39, n. 2, p. 266-271, 2010.

CAVANAGH, P. et al. Cost of treating diabetic foot ulcers in five different countries. Diabetes/Metabolism Research and Reviews, v. 28, p. 107-111, 2012. Suplemento 1.

CERVELLI, V. et al. Application of enhanced stromal vascular fraction and fat grafting mixed with PRP in post-traumatic lower extremity ulcers. Stem Cell Research, v. 6, n. 2, p. 103-111, 2011.

CERVELLI, V.; GENTILE, P.; GRIMALDI, M. Regenerative surgery: use of fat grafting combined with platelet-rich plasma for chronic lower-extremity ulcers. Aesthetic Plastic Surgery, v. 33, n. 3, p. 340-345, 2009. 
$\mathrm{CHEN}$, J. et al. The key regulatory roles of the PI3K/Akt signaling pathway in the functionalities of mesenchymal stem cells and applications in tissue regeneration. Tissue Engineering Part B Reviews, v. 19, n. 6, p. 516-528, 2013.

CHEN, L. et al. Paracrine factors of mesenchymal stem cells recruit macrophages and endothelial lineage cells and enhance wound healing. PLoS One, v. 3, n. 4, p. e1886, 2008.

CHU, D. H. et al. The structure and development of skin. In: FREEDBERG, I. M. et al. Fitzpatrick's Dermatology in General Medicine. $6^{\text {th }}$ ed. New York: McGraw-Hill Professional, 2003. v. 1, p. 58-88.

CLARK, R.A.F. (Ed.). The molecular and cellular biology of wound repair. $2^{\text {nd }}$ ed. New York: Plenum Press, 1996. 600 p.

DASH, N. R. et al. Targeting nonhealing ulcers of lower extremity in human through autologous bone marrow-derived mesenchymal stem cells. Rejuvenation Research, v. 12, n. 5, p. 359-366, 2009.

DA SILVA MEIRELLES, L.; CAPLAN, A. I.; NARDI, N. B. In search of the in vivo identity of mesenchymal stem cells. Stem Cells, v. 26, n. 9, p. 2287-2299, 2008.

DA SILVA MEIRELLES, L. et al. MSC frequency correlates with blood vessel density in equine adipose tissue. Tissue Engineering Part A, v. 15, n. 2, p. 221-229, 2009.

DELONG, J. M.; RUSSELL, R. P.; MAZZOCCA, A. D. Platelet Rich Plasma: The PAW Classification System. Arthroscopy, v. 28, n. 7, p. 998-1009, 2012.

DIONYSSIOU, D. et al. Effectiveness of intralesional injection of platelet-rich plasma in accelerating the healing of chronic ulcers: an experimental and clinical study. International Wound Journal, v.10, n. 4, p. 397-406, 2012.

OLIVEIRA, J. E. P.; VENCIO, S. (Org). Diretrizes da Sociedade Brasileira de Diabetes: 2014-2015/ Sociedade Brasileira de Diabetes. São Paulo: AC Farmacêutica, 2015.

DOMINICI, M. et al. Minimal criteria for defining multipotent mesenchymal stromal cells. The International Society for Cellular Therapy position statement. Cytotherapy, v. 8, n. 4, v. 315-317, 2006.

DRIVER, V.R. et al. A Prospective, Randomized, Controlled Trial of Autologous Platelet-Rich Plasma Gel for the Treatment of Diabetic Foot Ulcers. Ostomy/Wound Management, v. 52, n. 6, p. 68-87, 2006.

EBRAHIMIAN, T. et al. Cell therapy based on adipose tissue-derived stromal cells promotes physiological and pathological wound healing. Arteriosclerosis, Thrombosis and Vascular Biology, v. 29, n. 4, p. 503-510, 2009. 
FALANGA, V. Stem cells in tissue repair and regeneration. Journal of Investigative Dermatology, v. 132, n. 6, p. 1538-1541, 2012.

FALANGA, V. et al. Autologous bone marrow-derived cultured mesenchymal stem cells delivered in a fibrin spray accelerate healing in murine and human cutaneous wounds. Tissue Engineering, v. 13, n. 6, p. 1299-1312, 2007.

FORMIGLI, L. et al. Dermal matrix scaffold engineered with adult mesenchymal stem cells and platelet rich plasma as a potential tool for tissue repair and regeneration. Journal of Tissue Engineering and Regenerative Medicine, $v$. 6, n. 2, p. 125-134, 2012.

FOSTER, T.E. et al. Platelet-rich plasma: from basic science to clinical applications. The American Journal of Sports Medicine, v. 37, n. 11, p. 22592272, 2009.

FRIEDENSTEIN, A. J.; PIATETZKY-SHAPIRO, I.; PETRAKOVA, K.V. Osteogenesis in transplants of bone marrow cells. Journal of Embryology and Experimental Morphology, v.16, n. 3, p. 381-390, 1966.

FRIEDENSTEIN A. J. et al. Heterotopic of bone marrow. Analysis of precursor cells for osteogenic and hematopoietic tissues. Transplantation, v.6, n. 2, p. 230-247, 1968.

GAME, F. L. et al. Effectiveness of interventions to enhance healing of chronic ulcers of the foot in diabetes: a systematic review. Diabetes/Metabolism Research and Reviews, v. 32, p. 154-168, 2016. Suplemento 1.

GNECCHI, M. et al. Paracrine mechanisms in adult stem cell signaling and therapy. Circulation Research, v. 103, n. 11, p. 1204-1219, 2008.

GOULD, L. et al. Chronic wound repair and healing in older adults: current status and future research. Wound Repair and Regeneration, v. 23, n. 1, p. 113, 2015.

GURGEN, M. Treatment of chronic wounds with autologous platelet-rich plasma. EWMA Journal, v. 8, n. 2,p. 5-10, 2008.

HAIHONG, L.; XIAOBING, F. Mechanisms of action of mesenchymal stem cells in cutaneous wound repair and regeneration. Cell and Tissue Research, v. 348, n. 3, p. 371-377, 2012.

HANSON, S. E. et al. Local delivery of allogeneic bone marrow and adipose tissue-derived mesenchymal stromal cells for cutaneous wound healing in a porcine model. Journal of Tissue Engineering and Regenerative Medicine, v. 10, n. 2, E90-E100, 2016. 
HASSAN, W. U. I.; GREISER, U.; WANG, W. Role of adipose-derived stem cells in wound healing. Wound Repair and Regeneration, v. 22, n. 3, p. 313325, 2014.

HEIJNEN, H.; VAN DER SLUIJS, P. Platelet secretory behavior: as diverse as the granules...or not? Journal of Thrombosis and Haemostasis, v. 13, n. 12, p. 2141-2151, 2015.

HORWITZ, E. et al. International society for cellular therapy. Clarification of the nomenclature for MSC: the Internacional Society for Cellular Therapy position statement. Cytotherapy, v. 7, n. 5, p. 303-305, 2005.

HSU, C. W.; YUAN, K.; TSENG, C.C. The negative effect of plateletrich plasma on the growth of human cells is associated with secreted thrombospondin-1. Oral Surgery, Oral Medicine, Oral Pathology, Oral Radiology and Endodontics, v. 107, n. 2, p. 185-192, 2009.

HU, L. et al. Effects of adipose stem cell conditioned médium on the migration of vascular endothelial cells, fibroblasts and keratinocytes. Experimental and Therapeutic Medicine, v. 5, n. 3,p. 701-706, 2013.

HUANG, Q. et al. Preliminary separation of the growth factors in platelet-rich plasma: effects on the proliferation of human marrow-derived mesenchymal stem cells. Chinese Medical Journal, v. 122, n. 1, p. 83-87, 2009.

ISAAC, C. et al. Papel do queratinócito na contração da ferida: avaliação de impacto usando um modelo de matriz de colágeno povoada por fibroblastos. Revista Brasileira de Cirurgia Plástica, v. 26, n. 3, p. 402-406, 2011.

ISAAC, V.L.B. et al. Protocolo para ensaios físico-químicos de estabilidade de fitocosméticos. Revista de Ciências Farmacêuticas Básica e Aplicada, v. 19, n. 1, p. 81-96, 2008.

ISAKSON, M. et al. Mesenchymal stem cells and cutaneous wound healing current evidence and future potential. Stem Cells International, v. 2015, n. 831095, p. 1-12, 2015.

JO, C.H. et al. Optimizing platelet-rich plasma gel formation by varying time and gravitational forces during centrifugation. The Journal of Oral Implantology, v.39, n. 5, p. 525-532, 2013.

JUNQUEIRA, L.C.; CARNEIRO, J. Histologia Básica. 11a edição. Rio de Janeiro: Guanabara Koogan, 2008.

KAKUDO, N. et al. Proliferation-promoting effect of platelet-rich plasma on human adipose-derived stem cells and human dermal fibroblasts. Plastic and Reconstructive Surgery, v. 122, n. 5, p. 1352-1360, 2008. 
KAZAKOS, $\mathrm{K}$. et al. The use of autologous PRP gel as an aid in the management of acute traumawounds. Injury, v. 40, n. 8, p. 801-805, 2009.

$\mathrm{KIM}$, I. et al. Fibrin glue improves the therapeutic effect of MSCs by sustaining survival and paracrine function. Tissue Engineering Part A, v. 19, n. 21-22, p. 2373-2381, 2013.

KIM, W.S. et al. Wound healing effect of adipose-derived stem cells: a critical role of secretory factors on human dermal fibroblasts. Journal of Dermatological Science, v. 48, n. 1, p. 15-24, 2007.

KNIGHTON, D.R. et al. Classification and treatment of chronic nonhealing wounds. Successful treatment with autologous platelet-derived wound healing factors (PDWHF). Annals of Surgery, v. 204, n. 3, p. 322-330, 1986.

KONTOPODIS, N. et al. Effectiveness of platelet-rich plasma to enhance healing of diabetic foot ulcers in patients with concomitant peripheral arterial disease and critical limb ischemia. The International Journal of Lower Extremity Wounds, v. 15, n. 1, p. 45-51, 2016.

LEE, S.H. et al. Paracrine effects of adipose-derived stem cells on keratinocytes and dermal fibroblasts. Annals of Dermatology, v. 24, n. 2, p. 136-143, 2012.

LEE, S. H.; LEE, J. H.; CHO, K.H. Effects of human adipose-derived stem cells on cutaneous wound healing in nude mice. Annals of Dermatology, v. 23, n. 2, p. 150-155, 2011.

LEIBOVICH, S. J.; ROSS, R. The role of the macrophage in wound repair: A study with hydrocortisone and antimacrophage serum. The American Journal of Pathology, v. 78, n. 1, p. 71-100, 1975.

LEONE, S. et al. Epidemiology of diabetic foot. Le Infezioni in Medicina, v. 20, p. 8-13, 2012. Suplemento 1.

LIAN, Z. et al. Synergistic effect of bone marrow-derived mesenchymal stem cells and platelet-rich plasma in streptozotocin-induced diabetic rats. Annals of Dermatology, v. 26, n. 1, p. 1-10, 2014.

LIANG, C. C.; PARK, A. Y.; GUAN, J. L. In vitro scratch assay: a convenient and inexpensive method for analysis of cell migration in vitro. Nature Protocols, v. 2, n. 2, p. 329-333, 2007.

LIN, C.S. et al. Defining adipose tissue-derived stem cells in tissue and in culture. Histology and Histopathology, v. 25, n. 6, p. 807-815, 2010.

LUCARELLI, E. et al. Platelet-derived growth factors enhance proliferation of human stromal stem cells. Biomaterials, v. 24, n. 18, p. 3095-3100, 2003.

MALERBI, D.A.; FRANCO, L. J. Multicenter study of the prevalence of diabetes mellitus and impaired glucose tolerance in the urban Brazilian population aged 
30-69 yr. The Brazilian Cooperative Group on the Study of Diabetes Prevalence.Diabetes Care, v. 15, n. 11, p. 1509-1526, 1992.

MARGOLIS, D.J. et al. Effectiveness of platelet releasate for the treatment of diabetic neurophatic foot ulcers. Diabetes Care, v. 24, n. 3, p. 483-488, 2001.

MARKOVA, A.; MOSTOW, E. N. US skin disease assessment: ulcer and would care. Dermatologic Clinics, v. 30, n. 1, p. 107-111, 2012.

MARQUES, L. F. et al. Platelet-rich plasma (PRP): Methodological aspects and clinical applications. Platelets, v. 26, n. 2, p. 101-113, 2015.

MARQUEZ-CURTIS, L.A. et al. Mesenchymal stromal cells derived from various tissues: biological, clinical and cryopreservation aspects. Cryobiology, v. 71, n. 2, p. 181-197, 2015.

MARX, R.E. Platelet-rich plasma: evidence to support its use. Journal of Oral and Maxillofacial Surgery, v. 62, n. 4, p. 489-496, 2004.

MARX, R.E. et al. Platelet rich plasma: growth factor enhancement for bone grafts. Oral Surgery, Oral Medicine, Oral Pathology, Oral Radiology and Endodontics, v. 85, n. 6, p. 638-646, 1998.

MAXSON, S. et al. Concise review: role of mesenchymal stem cells in wound repair. Stem Cells Translational Medicine, v. 1, n. 2, p. 142-149, 2012.

MCFADYEN, J. D.; KAPLAN, Z. S. Platelets are not just for clots. Transfusion Medicine Reviews, v. 29, n. 2, p. 110-119, 2015.

MEHENDALE, F.; MARTIN, P. The cellular and molecular events of wound healing. In: FALANGA, V. (Ed.). Cutaneous Wound Healing. 1st ed. London: Martin Dunitz, 2001. p. 15-37.

MELTON, D. A.; COWAN, C. "Stemness": definitions, criteria, and standards. In: LANZA, R. (Ed.). Handbook of Stem Cells. New York: Elsevier/Academic Press; 2004. v.1, p. 25-31.

METCALFE, A. D.; FERGUSON, M.W. Skin stem and progenitor cells: using regeneration as a tissue-engineering strategy. Cellular and Molecular Life Sciences, v. 65, n. 1, p. 24-32, 2008.

MILLS, D. C.; ROBB, I. A.; ROBERTS, G.C. The release of nucleotides, 5hydroxytryptamine and enzymes from human blood platelets during aggregation. The Journal of Physiology, v.195, n. 3, p. 715-729, 1968.

MIZUNO, H. Adipose-derived stem cells for tissue repair and regeneration: Ten years of research and a literature review. Journal of Nippon Medical School, v. 76, n. 2, p. 56-66, 2009. 
MORONI, L.; FORNASARI, P.M. Human mesenchymal stem cells: a bank perspective on the isolation, characterization and potential of alternative sources for the regeneration of musculoskeletal tissues. Journal of Cellular Physiology, v. 228, n. 4, p. 680-687, 2013.

NAMBU, M. et al. Stimulatory effect of autologous adipose tissue-derived stromal cells in an atelocollagen matrix on wound healing in diabetic $\mathrm{db} / \mathrm{db}$ mice. Journal of Tissue Engineering, v. 2011, n. 158105, p. 1-7, 2011.

NAMBU, M. et al. Accelerated wound healing in healing-impaired db/db mice by autologous adipose tissue-derived stromal cells combined with atelocollagen matrix. Annals of Plastic Surgery, v. 62, n. 3, p.317-321, 2009.

NATIONAL INSTITUTE OF HEALTH $(\mathrm{NIH})$. Stem cells: scientific progress and future research direction. Bethesda, 2001.

NURDEN, A.T. Platelets, inflammation and tissue regeneration. Thrombosis and Haemostasis, v. 105, p. S13-S33, 2011. Suplemento 1.

OCHOCKI, J. D.; SIMON, M. C. Nutrient sensing pathways and metabolic regulation in stem cells. The Journal of Cell Biology, v. 203, n. 1, p. 23-33, 2013.

O'LOUGHLIN, A.; O'BRIEN, T. Topical stem and progenitor cell therapy for diabetic foot ulcers. In: GHOLAMREZANEZHAD, A. (Ed.). Stem cells in clinic and research. InTech. 2011. Disponível em: http://www.intechopen.com/books/stem-cells-in-clinic-and-research/topicalstem-and-progenitor-cell-therapy-for-diabetic-foot-ulcers. Acesso em: 23 Mar 2016.

Park, H.B.; Yang, J.H.; Chung, K.H. Characterization of the cytokine profile of platelet rich plasma (PRP) and PRP induced cell proliferation and migration: Upregulation of matrix metalloproteinase- 1 and -9 in HaCaT cells. The Korean Journal of Hematology, v. 46, n. 4, p. 265-273, 2011.

PEDROSA, H.C. Pé diabético: aspectos fisiopatológicos, tratamento e prevenção. Revista Brasileira de Neurologia e Psiquiatria, v. 1, p. 131-135, 1997.

PICARD, F. et al. The growing evidence for the use of platelet-rich plasma on diabetic chronic wounds: a review and a proposal for a new standard care. Wound Repair and Regeneration, v. 23, n. 5, p. 638-643, 2015.

PIERCE, G.F.; MUSTOC, T.A. Pharmacologic enhancement of wound healing. Annual Review of Medicine, v. 46, n. 467-481, 1995.

PILCHER, B.K. et al. The activity of collagenase- 1 is required for keratinocyte migration on a type I collagen matrix. The Journal of Cell Biology, v. 137, n. 6 , p. $1445-1457,1997$. 
PRADHAN, L. et al. Inflammation and neuropeptides: the connection in diabetic wound healing. Expert Reviews in Molecular Medicine, v. 11, p. e2, 2009.

REED, B. R., CLARK, R. A. Cutaneous tissue repair: practical implications of current knowledge. II. Journal of the American Academy of Dermatology, v. 13, n. 6. p. 919-941, 1985.

RIBEIRO-PAES, J.T. et al. Unicentric study of cell therapy in chronic obstructive pulmonary disease / pulmonary emphysema. International Journal of Chronic Obstructive Pulmonary Disease, v. 6, p. 63-71, 2011.

ROUBELAKIS, M.G. et al. Platelet-rich plasma (PRP) promotes fetal mesenchymal stem/stromal cell migration and wound healing process. Stem Cell Reviews, v. 10, n. 3, p. 417-428, 2014.

RUMBAUT, R.E.; THIAGARAJAN, R. Platelet-vessel wall interactions in hemostasis and thrombosis. San Rafael: Morgan \& Claypool Life Sciences, $2010.75 \mathrm{p}$.

SAMPAIO, S. A. P.; RIVITTI, E.A. Dermatologia. 3a ed. São Paulo: Artes Médicas, $2007.1600 \mathrm{p}$.

SASAKI, M. et al. Mesenchymal stem cells are recruited into wounded skin and contribute to wound repair by transdifferentiation into multiple skin cell type. Jounal of Immunology, v.180, n. 4, p. 2581-2587, 2008.

SCARANTO, M.K. Plasma Rico em Plaquetas. 2002. 27 f. Monografia (Especialização em Periodontia) - Centro de Ciências da Saúde, Departamento de Estomatologia, Universidade Federal de Santa Catarina, Santa Catarina, 2002.

SCHEPULL, T. et al. Autologous platelets have no effect on the healing of human Achilles tendon ruptures a randomized single-blind study. The American Journal of Sports Medicine, v. 39, n. 1, p. 38-47, 2011.

SHAI, A.; MAIBACH, H. I. Wound healing and ulcers of the skin. Diagnosis and Therapy - The Practical Approach. Germany: Springer Berlin Heidelberg New York, 2005.270 p.

SHAN, G. Q. et al. Evaluation of the effects of homologous platelet gel on healing lower extremity wounds in patients with diabetes. The International Journal of Lower Extremity Wounds, v. 12, n. 1, p. 22-29, 2013.

SINGER, A.J.; CLARK, R.A. Cutaneous wound healing.The New England Journalof Medicine, v. 341, n. 10, p. 738-746, 1999.

SORRELL, J. M.; CAPLAN, A. I. Topical delivery of mesenchymal stem cells and their function in wounds. Stem Cell Research \& Therapy, v. 1, n. 30, p. 16, 2010. 
STEED, D.L. et al. Randomized prospective double-blinded trial in healing chronic diabetic foot ulcers. CT-102 activated platelet supernatant, topical versus placebo. Diabetes Care, v. 15, n. 11, 1598-1604, 1992.

STESSUK, T. et al. Phase I clinical trial of cell therapy in patients with chronic obstructive pulmonary disease: follow up of up to 3 years. Revista Brasileira de Hematologia e Hemoterapia, v. 35, n. 5, p. 352-357, 2013.

TRZECIAK-RYCZEK, A.; TOKARZ-DEPTULA, B.; DEPTULA, W. Platelets - an important element of the immune system. Polish Journal of Veterinary Sciences, v. 16, n. 2, p. 407-413, 2013.

VENDRAMIN, F. S.; FRANCO, D.; FRANCO, T.R. Método de obtenção do gel de plasma rico em plaquetas autólogo. Revista Brasileira de Cirurgia Plástica, v. 24, n. 2, p. 212-218, 2009.

VERMEULEN, R. et al. A plasma-based biomatrix mixed with endothelial progenitor cell and keratinocytes promotes matriz formation, angiogenesis and reepithelization in full thickness wounds. Tissue Engineering Part A, v. 15, n. 7, p. 1533-1542, 2009.

$\mathrm{XIE}, \mathrm{X}$. et al. Comparative evaluation of MSCs from bone marrow and adipose tissue seeded in PRP-derived scaffold for cartilage regeneration. Biomaterials, v. 33, n. 29, p. 7008-7018, 2012.

ZANELATO, T.P. et al. Implante de fragmentos de lóbulos de gordura autóloga na esclerodermia localizada e na lipoatrofia idiopática - Relato de cinco pacientes. Anais Brasileiros de Dermatologia, v. 88, n. 6, p. 120-123, 2013. Suplemento 1.

ZHAO, J. et al. The effects of cytokines in adipose stem cells conditioned medium on the migration and proliferation of skin fibroblasts in vitro. BioMed Research International, v. 2013, n. 578479, p. 1-11, 2013.

ZUK, P.A. et al. Multilineage cells from human adipose tissue: implications for cell-based therapies. Tissue Engineering, v. 7, n. 2, p. 211-228, 2001.

YANG, H.S. et al. Enhanced skin wound healing by a sustained release of growth factors contained in platelet-rich plasma. Experimental \& Molecular Medicine, v. 43, n. 11, p. 622-629, 2011.

YANG, M. et al. Stem cell therapy for lower extremity diabetic ulcers: where do we stand? Biomed Research International, v. 2013, n. 462179, p. 1-8, 2013.

YOO, K.H. et al. Comparison of immunomodulatory properties of mesenchymal stem cells derived from adult human tissues. Cellular Immunology, v. 259, n. 2, p. 150-156, 2009. 
YOSHIMURA, K.; SUGA, H.; ETO, H. Adipose-derived stem /progenitor cells: roles in adipose tissue remodeling and potential use for soft tissue augmentation. Regenerative Medicine, v. 4, n. 2,p. 265-273, 2009.

WALTER, M. N.; et al. Mesenchymal stem cell-conditioned medium accelerates skin wound healing: an in vitro study of fibroblast and keratinocyte scratch assays.Experimental Cell Research, v. 316, n. 7, p. 1271-1281, 2010.

WERNER, S.; KRIEG, T.; SMOLA, H. Keratinocyte-Fibroblast Interactions in Wound Healing. Journal of Investigative Dermatology, v. 127, n. 5, p. 9981008, 2007.

WILD, S. et al. Global prevalence of diabetes: estimates for the year 2000 and projections for 2030. Diabetes Care, v. 27, n. 5, p. 1047-1053, 2004.

WONG, V. W.; GURTNER, G. C. Tissue engineering for the management of chronic wounds: current concepts and future perspectives. Experimental Dermatology, v. 21, n. 10, p. 729-734, 2012. 


\section{ANEXOS}

\section{Anexo A}

\section{TERMO DE CONSENTIMENTO LIVRE E ESCLARECIDO}

- Você está sendo convidado (a) a participar de uma pesquisa. Pedimos que entenda detalhadamente todas as etapas e, se concordar, assine este termo de consentimento;

- Todas as dúvidas surgidas durante e após o trabalho serão prontamente esclarecidas. Você também poderá entrar em contato com o Comitê de Ética em Pesquisa da Faculdade de Ciências Médicas da UNICAMP para fazer reclamações e/ou denúncias referentes aos aspectos éticos do estudo;

- O objetivo deste estudo é avaliar a influência de células-tronco derivadas do tecido adiposo e plasma rico em plaquetas sobre culturas de células da pele: fibroblastos, queratinócitos e melanócitos;

- Para isso, será utilizado plasma de plaquetas proveniente do sangue de doadores humanos. A coleta será realizada no Hemocentro da UNICAMP e aproximadamente $450 \mathrm{~mL}$ de sangue serão coletados para compor uma bolsa. O material coletado será enviado ao Laboratório de Cultura de Células da Pele no Centro de Investigação em Pediatria (CIPED), da Faculdade de Ciências Médicas (FCM) da UNICAMP, onde será processado com o propósito de obter o plasma rico em plaquetas. Sua identidade será preservada;

- Participando deste estudo, você estará contribuindo para aumentar o conhecimento científico existente sobre a terapia com células-tronco e plasma rico em plaquetas em úlceras cutâneas;

- Conforme legislação em vigor, você não receberá nenhuma quantia em dinheiro;

- Você não precisará utilizar nenhum medicamento ou outra substância;

- Você poderá se retirar da pesquisa a qualquer instante se assim desejar ou, se necessário, a critério do pesquisador;

- A pesquisa será realizada na Disciplina de Dermatologia, Departamento de Clínica Médica, e Laboratório de Cultura de Células da Pele - CIPED, FCM, UNICAMP, Barão Geraldo, Campinas - SP - Brasil;

- Sua contribuição voluntária será de grande importância para o nosso trabalho;

- Todas as informações obtidas sobre os doadores serão mantidas em sigilo;

- Uma via deste termo permanecerá no Laboratório de Cultura de Células da Pele e a outra será entregue ao voluntário.

Todos os itens acima foram lidos e esclarecidos, em voz alta, para o voluntário.

$\mathrm{Eu}$, nascido (a) em ' $\frac{1}{\mathrm{e}}{ }^{\prime} \frac{\mathrm{CPF}}{\mathrm{C}}$

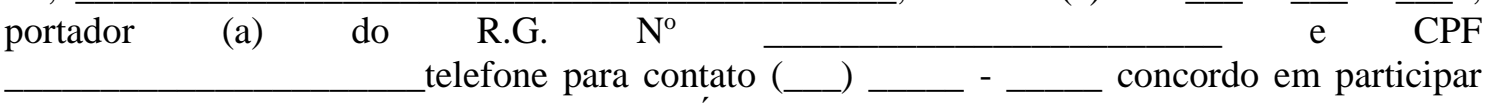
do estudo "TERAPIA CELULAR EM ÚLCERAS VENOSAS COM IMPLANTE DE CÉLULAS-TRONCO MESENQUIMAIS ASSOCIADAS A PLASMA RICO EM PLAQUETAS" e declaro ter sido esclarecido (a) sobre todos os itens acima.

Assinatura do doador 
Testemunha (nome e sobrenome completos sem abreviações)

Assinatura

R.G.

$\mathrm{CPF}$

Responsável por aplicar o TCLE

Assinatura

R.G.

$\mathrm{CPF}$

Orientadora Responsável- MARIA BEATRIZ PUZZI

Professora Associada do Departamento de Clinica Médica da Faculdade de Ciências Medicas da Universidade Estadual de Campinas

Endereço: Cidade Universitária Prof ${ }^{\circ}$ Zeferino Vaz s/nº Caixa Postal 6111

Campinas-SP_- CEP: 13081-9709

Telefone (19) 35218988

Fax: (19)35218080

Pesquisadora Responsável- TALITA STESSUK

Doutoranda pelo Programa de Pós Graduação Interunidades em Biotecnologia - Universidade de São Paulo

Endereço: Cidade Universitária Prof ${ }^{\circ}$ Zeferino Vaz s/nº Caixa Postal 6111

Campinas-SP_-CEP: 13081-9709

Telefone (19) 35218988

Fax: (19)35218080

Comitê de Ética em Pesquisa da Faculdade de Ciências médicas da UNICAMP

Rua: Tessália Vieira de Camargo, 126

Distrito de Barão Geraldo

Campinas - SP

CEP: $13083-887$

(19) 35218936

email: cep@fcm.unicamp.br

Campinas, de de 


\section{Anexo B}

\section{TERMO DE CONSENTIMENTO LIVRE E ESCLARECIDO}

- Você está sendo convidado (a) a participar de uma pesquisa. Pedimos que entenda todas as etapas e, se concordar, assine este termo de consentimento;

- Todas as dúvidas surgidas durante e após o trabalho serão prontamente esclarecidas. Você também poderá entrar em contato com o Comitê de Ética em Pesquisa da Faculdade de Ciências Médicas da UNICAMP;

- O objetivo deste estudo é avaliar a influência de células-tronco do tecido adiposo e plasma rico em plaquetas sobre células da pele (fibroblastos, queratinócitos e melanócitos);

- Para isso, serão utilizadas culturas de células-tronco mesenquimais do tecido adiposo de doadores humanos. Essas células serão obtidas da gordura retirada durante procedimento cirúrgico (cirurgia bariátrica). As culturas de células-tronco mesenquimais serão provenientes de fragmento de tecido adiposo, cerca de 10 a 20 gramas, coletado da área da região subcutânea abdominal, acondicionado em soro fisiológico 0,9\%. O material coletado será enviado ao Laboratório de Cultura de Células da Pele (LCCP) no Centro de Investigação em Pediatria (CIPED), da Faculdade de Ciências Médicas (FCM) da UNICAMP, onde serão realizadas as culturas de células-tronco mesenquimais. Sua identidade será preservada;

- Participando deste estudo, você estará contribuindo para aumentar o conhecimento científico existente sobre a terapia com células-tronco em úlceras de perna;

- Você não precisará utilizar nenhum medicamento ou outra substância;

- Conforme legislação em vigor, você não receberá nenhuma quantia em dinheiro;

- Você poderá se retirar da pesquisa a qualquer instante se assim desejar ou, se necessário, a critério do pesquisador;

- A pesquisa será realizada na Disciplina de Dermatologia, Departamento de Clínica Médica, e Laboratório de Cultura de Células da Pele - CIPED, FCM, UNICAMP, Barão Geraldo, Campinas - SP - Brasil;

- Sua contribuição voluntária será de grande importância para o nosso trabalho;

- Todas as informações obtidas sobre os doadores serão mantidas em sigilo;

- Uma via deste termo permanecerá no Laboratório de Cultura de Células da Pele e a outra será entregue ao voluntário.

Todos os itens acima foram lidos e esclarecidos, em voz alta, para o voluntário.

$\mathrm{Eu}$, , nascido (a) em I 1

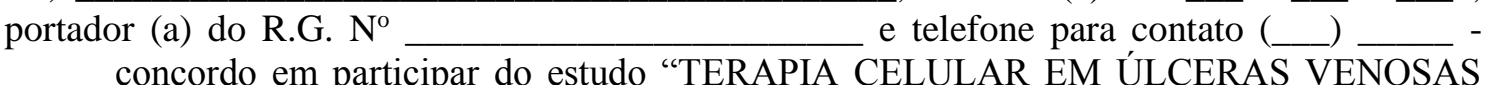
$\overline{C O M}$ IMPLANTE DE CÉLULAS-TRONCO MESENQUIMAIS ASSOCIADAS A PLASMA RICO EM PLAQUETAS” e declaro ter sido esclarecido (a) sobre todos os itens acima.

Assinatura do (a) voluntário (a) (igual ao R.G. ou CNH) 
R.G.

$\mathrm{CPF}$

Testemunha (nome e sobrenome completos sem abreviações)

Assinatura

R.G.

$\mathrm{CPF}$

Testemunha (nome e sobrenome completos sem abreviações)

Assinatura

R.G.

$\mathrm{CPF}$

Testemunha (nome e sobrenome completos sem abreviações)

Assinatura

R.G.

$\mathrm{CPF}$

Responsável por aplicar o TCLE

Assinatura

R.G.

$\mathrm{CPF}$

Orientadora Responsável- MARIA BEATRIZ PUZZI

Professora Associada do Departamento de Clinica Médica da Faculdade de Ciências Medicas da Universidade Estadual de Campinas

Endereço: Cidade Universitária Prof ${ }^{\circ}$ Zeferino Vaz s/n Caixa Postal 6111

Campinas-SP_-CEP: 13081-9709

Telefone (19) 35218988

Fax: (19)35218080

Pesquisadora Responsável- TALITA STESSUK

Doutoranda pelo Programa de Pós Graduação Interunidades em Biotecnologia - Universidade de São Paulo

Endereço: Cidade Universitária Prof ${ }^{\circ}$ Zeferino Vaz s/n Caixa Postal 6111

Campinas-SP_-CEP: 13081-9709

Telefone (19) 35218988

Fax: (19)35218080

Telefone do Comitê de Ética em Pesquisa da Faculdade de Ciências médicas da UNICAMP (19) 35218936

Campinas, de de 


\section{Anexo C}

\section{TERMO DE CONSENTIMENTO LIVRE E ESCLARECIDO}

- Você está sendo convidado (a) a participar de uma pesquisa. Pedimos que entenda detalhadamente todas as etapas e, se concordar, assine este termo de consentimento;

- Todas as dúvidas surgidas durante e após o trabalho serão prontamente esclarecidas. Você também poderá entrar em contato com o Comitê de Ética em Pesquisa da Faculdade de Ciências Médicas da UNICAMP;

- O objetivo deste estudo é avaliar a influência de células-tronco derivadas do tecido adiposo e plasma rico em plaquetas sobre culturas de células da pele: fibroblastos, queratinócitos e melanócitos;

- Para isso, serão utilizadas culturas de fibroblastos e queratinócitos de doadores humanos. Essas células serão obtidas da pele retirada durante procedimento cirúrgico para correção da pálpebra (blefaroplastia). As culturas de fibroblastos e queratinócitos serão provenientes de fragmentos de pele da pálpebra removida e destinada ao descarte. O material coletado será acondicionado em soro físiológico 0,9\% e enviado ao Laboratório de Cultura de Células da Pele no Centro de Investigação em Pediatria (CIPED), da Faculdade de Ciências Médicas (FCM) da UNICAMP, onde será processado com o propósito de obter as culturas de fibroblastos e queratinócitos. Sua identidade será preservada;

- Participando deste estudo, você estará contribuindo para aumentar o conhecimento científico existente sobre a terapia com células-tronco e plasma rico em plaquetas em úlceras cutâneas;

- Conforme legislação em vigor, você não receberá nenhuma quantia em dinheiro;

- Você não precisará utilizar nenhum medicamento ou outra substância;

- Você poderá se retirar da pesquisa a qualquer instante se assim desejar ou, se necessário, a critério do pesquisador;

- A pesquisa será realizada na Disciplina de Dermatologia do Departamento de Clínica Médica, e no Laboratório de Cultura de Células da Pele - CIPED, FCM, UNICAMP, Barão Geraldo, Campinas - SP - Brasil;

- Sua contribuição voluntária será de grande importância para o nosso trabalho;

- Todas as informações obtidas sobre os doadores serão mantidas em sigilo;

- Uma via deste termo permanecerá no Laboratório de Cultura de Células da Pele e a outra será entregue ao voluntário.

Todos os itens acima foram lidos e esclarecidos, em voz alta, para o voluntário.

$\mathrm{Eu}$, nascido (a) em

' $\frac{}{\mathrm{e}}{ }^{\prime} \overline{\mathrm{CPF}}$

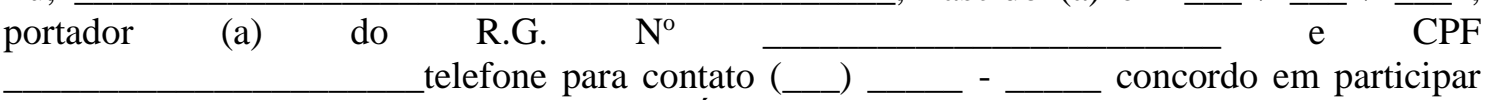
do estudo "TERAPIA CELULAR EM ÚLCERAS VENOSAS COM IMPLANTE DE CÉLULAS-TRONCO MESENQUIMAIS ASSOCIADAS A PLASMA RICO EM PLAQUETAS" e declaro ter sido esclarecido (a) sobre todos os itens acima.

Assinatura do doador

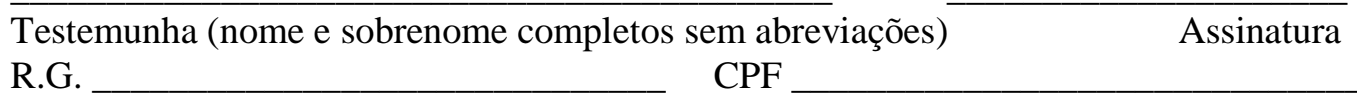

Responsável por aplicar o TCLE R.G.
$\mathrm{CPF}$
Assinatura 
Orientadora Responsável- MARIA BEATRIZ PUZZI

Professora Associada do Departamento de Clinica Médica da Faculdade de Ciências Medicas da Universidade Estadual de Campinas

Endereço: Cidade Universitária Prof ${ }^{\circ}$ Zeferino Vaz s/no Caixa Postal 6111

Campinas-SP_-CEP: 13081-9709

Telefone (19) 35218988

Fax: (19)35218080

Pesquisadora Responsável- TALITA STESSUK

Doutoranda pelo Programa de Pós Graduação Interunidades em Biotecnologia - Universidade de São Paulo

Endereço: Cidade Universitária Prof ${ }^{\circ}$ Zeferino Vaz s/no Caixa Postal 6111

Campinas-SP_-CEP: 13081-9709

Telefone (19) 35218988

Fax: (19)35218080

Telefone do Comitê de Ética em Pesquisa da Faculdade de Ciências médicas da UNICAMP (19) 35218936

Campinas, de de 


\section{Anexo D}

\section{TERMO DE CONSENTIMENTO LIVRE E ESCLARECIDO}

- Você está sendo convidado (a) a participar de uma pesquisa. Pedimos que entenda todas as etapas e, se concordar, assine este termo de consentimento;

- Todas as dúvidas surgidas durante e após o trabalho serão prontamente esclarecidas pelos pesquisadores. Você também poderá entrar em contato com o Comitê de Ética em Pesquisa da Faculdade de Ciências Médicas da UNICAMP;

- O objetivo deste estudo é avaliar a eficiência de células-tronco mesenquimais da gordura em conjunto com plasma rico em plaquetas (PRP) do sangue para o tratamento de úlceras de perna.

- Para isso, será realizado uma coleta de gordura na região da prega glútea, mediante anestesia local, para obtenção e isolamento das células-tronco mesenquimais em laboratório. Após processamento e cultivo das células, aproximadamente 25 dias, o(a) $\operatorname{sr}(a)$ será convocado(a) para uma coleta de sangue para obtenção do PRP em gel. As células-tronco mesenquimais que foram cultivadas serão colocadas junto com o PRP em gel e aplicadas sobre a úlcera de uma perna. A úlcera da outra perna será considerada controle e receberá tratamento convencional oferecido pelo ambulatório de Feridas da Disciplina de Dermatologia e o ambulatório de Úlceras Venosas da Disciplina de Cirurgia Vascular do Departamento de Cirurgia, ambos os ambulatórios da Faculdade de Ciências Médicas da Universidade Estadual de Campinas UNICAMP. Haverá acompanhamento semanal durante 90 dias ou até que a úlcera cicatrize. A avaliação será realizada por fotografias com câmera fotográfica digital.

- Participando deste estudo, você estará contribuindo para aumentar o conhecimento científico existente sobre a terapia com células-tronco em úlceras cutâneas;

- Conforme legislação em vigor, você não receberá nenhuma quantia em dinheiro;

- Você não precisará utilizar nenhum medicamento ou outra substância;

- Você poderá se retirar da pesquisa a qualquer instante se assim desejar ou, se necessário, a critério do pesquisador e isto não prejudicará o atendimento convencional oferecido pelo ambulatório do Hospital de Clínicas da UNICAMP;

- A pesquisa será realizada na Disciplina de Dermatologia do Departamento de Clínica Médica, e no Laboratório de Cultura de Células da Pele - CIPED, FCM, UNICAMP, Barão Geraldo, Campinas - SP - Brasil;

- Sua contribuição voluntária será de grande importância para o nosso trabalho;

- Todas as informações obtidas sobre os pacientes serão mantidas em sigilo;

- Uma via deste termo permanecerá no Laboratório de Cultura de Células da Pele e a outra será entregue ao paciente.

Todos os itens acima foram lidos e esclarecidos, em voz alta, para o paciente.

\section{TERMO DE CONSENTIMENTO LIVRE E ESCLARECIDO}

Projeto de Pesquisa- "TERAPIA CELULAR EM ÚLCERAS VENOSAS COM IMPLANTE DE CÉlULAS- TRONCO MESENQUIMAIS ASSOCIADAS A PLASMA RICO EM PLAQUETAS"

$\mathrm{Eu}$ (nome completo)

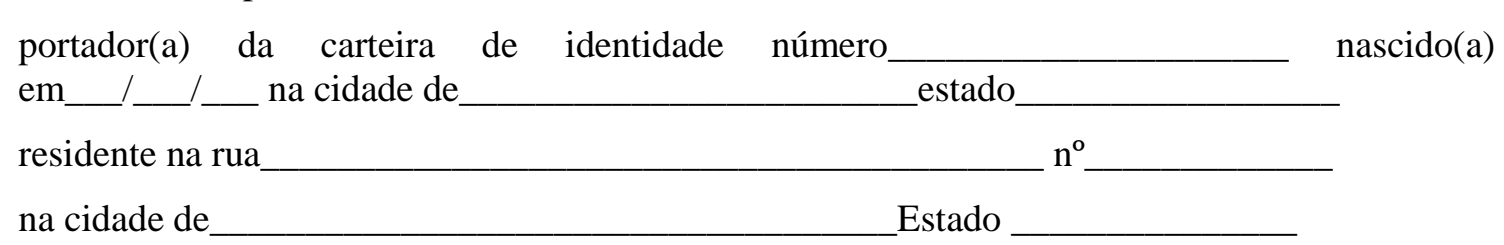


telefone: , declaro estar ciente de que participarei de um projeto de pesquisa para o tratamento de úlceras de perna, sob responsabilidade da $\operatorname{Prof}^{\mathrm{a}} \operatorname{Dr}^{\mathrm{a}}$ Maria Beatriz Puzzi, da Disciplina de Dermatologia da Faculdade de Ciências Médicas da Unicamp.

Este tratamento consiste na retirada de um fragmento de tecido adiposo na região da prega glútea, o que será feito com anestesia local e posterior sutura. Esta gordura será preparada (em torno de vinte e cinco dias) e após esse preparo serão coletados $70 \mathrm{~mL}$ de sangue para obtenção do plasma rico em plaquetas. As células tronco serão associadas ao plasma rico em plaquetas em gel e aplicadas sobre a úlcera.

Para os pacientes que não obtiverem sucesso com esta terapêutica, serão instituídas medidas adequadas (tratamento convencional).

Fui informado(a) e orientado(a) quanto à pesquisa, que terei a garantia do esclarecimento de qualquer dúvida sobre os assuntos relacionados a esta pesquisa, e que tenho assegurado o direito ao sigilo sobre estas informações, e que minha identificação não será exposta nas conclusões e publicações deste trabalho. Também estou ciente da possibilidade de interromper o tratamento, se necessário, por motivos particulares e/ou relacionados à pesquisa.

\section{Orientadora Responsável- MARIA BEATRIZ PUZZI}

Professora Associada do Departamento de Clinica Médica da Faculdade de Ciências Medicas da Universidade Estadual de Campinas

Endereço: Cidade Universitária Prof ${ }^{\circ}$ Zeferino Vaz s/nº Caixa Postal 6111

Campinas-SP_-CEP: 13081-9709

Telefone (19) 35218988

Fax: (19)35218080

\section{Pesquisadora Responsável- TALITA STESSUK}

Doutoranda pelo Programa de Pós Graduação Interunidades em Biotecnologia - Universidade de São Paulo

Endereço: Cidade Universitária Prof ${ }^{\circ}$ Zeferino Vaz s/nº Caixa Postal 6111

Campinas-SP_-CEP: 13081-9709

Telefone (19) 35218988

Fax: (19)35218080

Telefone do Comitê de Ética em Pesquisa da Faculdade de Ciências médicas da UNICAMP (19) 35218936

Campinas, de de

Paciente

Nome do pesquisador:

Assinatura 